\title{
One Pot Use of Combilipases for Full Modification of Oils and Fats: Multifunctional and Heterogeneous Substrates
}

\author{
Sara Arana-Peña ${ }^{1,+}{ }^{\dagger}$ Diego Carballares ${ }^{1,+}$, Ángel Berenguer-Murcia ${ }^{2}$, Andrés R. Alcántara ${ }^{3}{ }^{\oplus}$, \\ Rafael C. Rodrigues $4, *$ (D) and Roberto Fernandez-Lafuente ${ }^{1, *(D)}$ \\ 1 Departamento de Biocatálisis, ICP-CSIC, Campus UAM-CSIC, 28049 Madrid, Spain; s.arana@csic.es (S.A.-P.); \\ diego.carballares@csic.es (D.C.) \\ 2 Departamento de Química Inorgánica e Instituto Universitario de Materiales, Universidad de Alicante, \\ 03080 Alicante, Spain; a.berenguer@ua.es \\ 3 Departamento de Química en Ciencias Farmacéuticas, Facultad de Farmacia, Universidad Complutense \\ de Madrid, Plaza de Ramón y Cajal, s/n. 28040 Madrid, Spain; andalcan@ucm.es \\ 4 Biocatalysis and Enzyme Technology Lab, Institute of Food Science and Technology, Federal University of \\ Rio Grande do Sul, Av. Bento Gonçalves, P.O. Box 15090, Porto Alegre 9500, Brazil \\ * Correspondence: rafaelcrodrigues@ufrgs.br (R.C.R.); rfl@icp.csic.es (R.F.-L.); Tel.: +55-513-308-7793 (R.C.R.); \\ +34-915-854-804 (R.F.-L.) \\ + Both authors have evenly contributed to this paper.
}

Received: 12 May 2020; Accepted: 27 May 2020; Published: 29 May 2020

check for

\begin{abstract}
Lipases are among the most utilized enzymes in biocatalysis. In many instances, the main reason for their use is their high specificity or selectivity. However, when full modification of a multifunctional and heterogeneous substrate is pursued, enzyme selectivity and specificity become a problem. This is the case of hydrolysis of oils and fats to produce free fatty acids or their alcoholysis to produce biodiesel, which can be considered cascade reactions. In these cases, to the original heterogeneity of the substrate, the presence of intermediate products, such as diglycerides or monoglycerides, can be an additional drawback. Using these heterogeneous substrates, enzyme specificity can promote that some substrates (initial substrates or intermediate products) may not be recognized as such (in the worst case scenario they may be acting as inhibitors) by the enzyme, causing yields and reaction rates to drop. To solve this situation, a mixture of lipases with different specificity, selectivity and differently affected by the reaction conditions can offer much better results than the use of a single lipase exhibiting a very high initial activity or even the best global reaction course. This mixture of lipases from different sources has been called "combilipases" and is becoming increasingly popular. They include the use of liquid lipase formulations or immobilized lipases. In some instances, the lipases have been coimmobilized. Some discussion is offered regarding the problems that this coimmobilization may give rise to, and some strategies to solve some of these problems are proposed. The use of combilipases in the future may be extended to other processes and enzymes.
\end{abstract}

Keywords: lipases; combilipases; enzyme specificity; full modification; coimmobilization; cascade reaction

\section{Introduction}

\subsection{Enzymatic Biocatalysis}

Enzymes are extremely precise biocatalysts, exhibiting this precision in a chemo-, regio- and stereo- product selective manner when applied in biotransformations at lab or industrial scale, so that 
their use has been gaining a preponderant role in the last years etc. [1-10]. This may be coupled with high substrate specificity (e.g., stereospecificity) [11-22]. Additionally, the sustainability upgrade upon switching from chemical catalysis to biocatalysis is another aspect to be taken into account, as long as Biocatalysis and Green Chemistry present many common features [23-25]; in fact, considering the type of catalyst used, enzymes are obtained from easily accessible renewable sources are biodegradable and fundamentally innocuous and harmless, and their use generally avoids the need for toxic and expensive metals. From the point of view of the biocatalyzed process, reaction conditions are usually very mild (atmospheric pressure, room temperature), and many protection-deprotection steps can be avoided, therefore leading to more economical synthetic routes, also generating less waste than conventional processes $[16,18]$.

Although enzymes are very precise performing their catalytic activity, it is also true that in many cases it is necessary to increase their activity versus industrially relevant substrates (in some instances far from the physiological ones) and/or stability for making them compatible with operational conditions, mainly at the industrial level [26]. For this aim, there are several accepted strategies. One simple strategy is to exploit Nature to obtain the enzyme that best fits the specific process development, with a great advancement in metagenomics tools [27-31].

The genetic improving of enzymes by means of rational (or semirational) design [32-37], directed evolution [4,38-45] or even de novo enzyme design [46-49] helped with machine-learning technologies [50-53], a very powerful (although rather complex) approach. The chemical modification of enzymes is also a usual technique to improve enzyme features [54-57]. Enzyme immobilization, that was initialized as a way to solve the problem of enzyme solubility, is also an extremely useful methodology for modulating enzymatic features such as activity, selectivity, stability, etc. [9,32,58-70]. As lipases are one of the most (if not the most) frequently used biocatalysts [71-76], it is not surprising to find a plethora of immobilization protocols described for these enzymes [77-82]. Interestingly, in many instances some strategies to improve enzyme features are combined. For example, immobilization is compatible with any other strategy [55,83-87].

One very interesting paper shows the integrated use of diverse techniques to get an enzyme with new properties. It is related to the creation of an enzyme bearing an ex novo-created active center, to generate the so called plurizymes, using protein modelling and site-directed mutagenesis [88]. The same research group, in a further paper, exemplified how the coupled utilization of several tools may drive to results beyond expectations. In a second step, using dynamic simulation, protein modelling and directed mutagenesis, the plurizyme second active center activity was improved [89]. Then, an irreversible covalent inhibitor was designed, bearing a catalytic metal complex. This was attached to just one of the Ser located in the active centers, enabling a fully directed chemical modification of the plurizyme, and finally the artificial semimetal plurizyme was used in a cascade reaction involving both, the enzyme active center and the metal catalysts [89].

\subsection{Enzymatic Full Modification of the Substrate}

\subsubsection{Modification of Monofunctional Substrates}

When using monofunctional substrates, the enzyme must be selected to recognize and perform the reaction in an optimal way [90-92]. The situation is apparently simple-only one substrate and one product may exist in the reaction medium. However, even using monofunctional substrates, some changes in the reaction conditions may occur that can significantly affect the enzyme performance. For example, if the reaction is an ester hydrolysis performed without $\mathrm{pH}$ control, it is likely that the $\mathrm{pH}$ of the reaction medium decreases during reaction, and the intensity of this $\mathrm{pH}$ decrease will be related to the concentration of the substrate (Figure 1). The effect of $\mathrm{pH}$ should be considered on enzyme properties, including activity, before select the optimal enzyme for the process [92-96]. A similar $\mathrm{pH}$ decrease is found in the hydrolysis of some amides, e.g., $\beta$-lactamic antibiotics, where the amino group has a significantly low $\mathrm{pK}$ value (under $\mathrm{pH}$ 5) [97-100]. If that is the case, it is also likely that the 
optimal enzyme under the initial conditions may not be the optimal under the final reaction conditions. In this situation, it is sensible to think that the selection of the "best" enzyme to catalyze this reaction may be more complex that it initially seems. The use of initial rates under initial conditions will provide incomplete information that can lead to erroneous conclusions when considering the full reaction course (Figure 1). Full reaction courses using the target substrate concentrations should be considered to actually identify the best enzyme for a specific process. In some cases, it is not unlikely that the use of several enzymes may be a more convenient strategy, one with optimal activity under the initial reaction conditions, another with optimal activity under the final reaction conditions. The amount and proportion of both enzymes should be optimized in each specific case (kinetics of the enzymes with the substrate, concentration of the substrate, initial $\mathrm{pH}$ value, etc.). However, we have been unable to find any example of this use of enzyme mixtures. The situation will be different when using a high concentration of buffer that can maintain the $\mathrm{pH}$ throughout the reaction (but this can complicate the final downstream of the product) or if the $\mathrm{pH}$ value is controlled by continuous titration (but the titrating agent may affect the enzyme, substrate or product stabilities) $[60,61]$ (Figure 1).
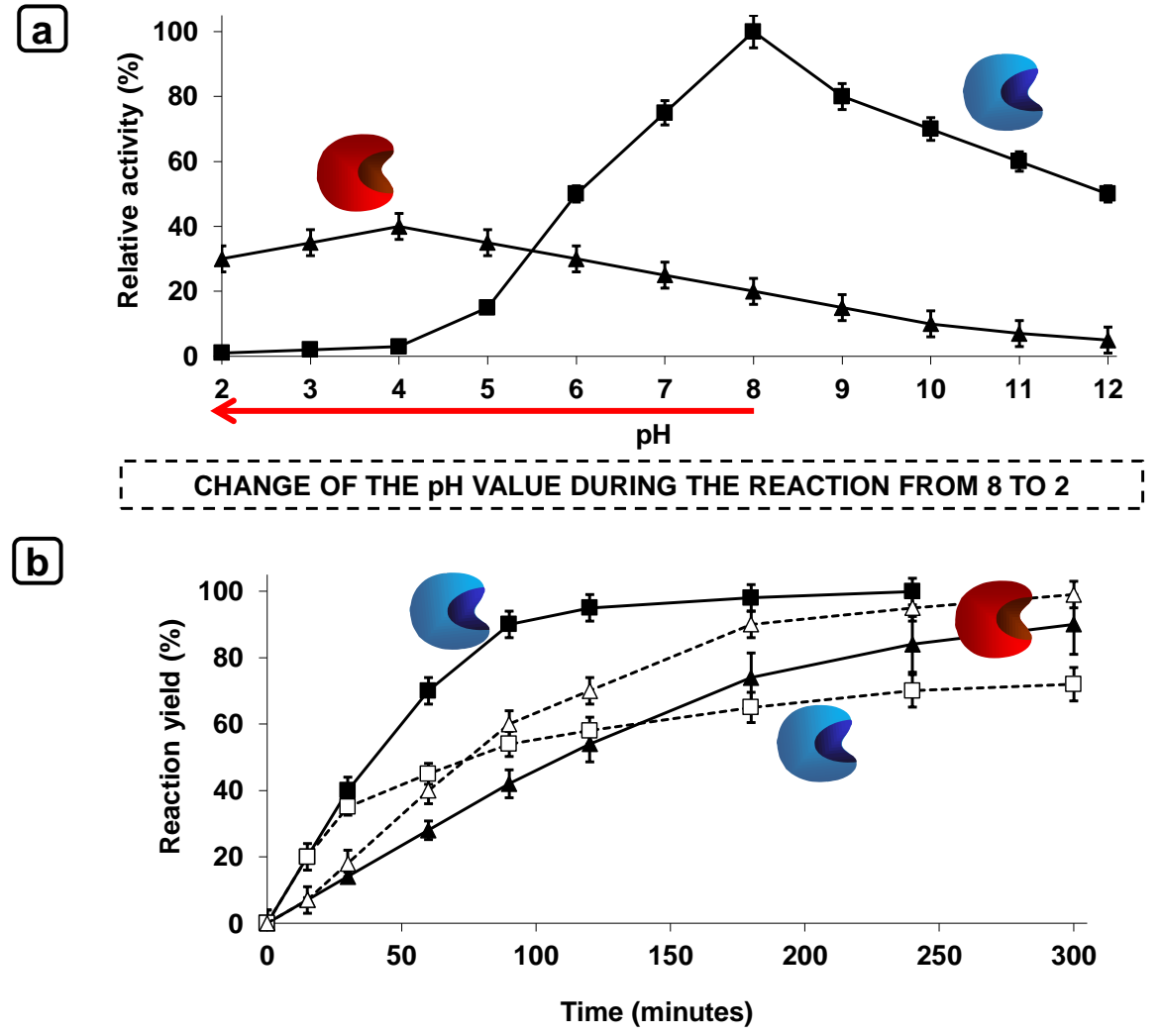

Figure 1. Effect of the change in the $\mathrm{pH}$ value during the reaction on the selection of the optimal enzyme. Figure represents two theoretical enzymes, one with high activity at optimal $\mathrm{pH}$ (initial $\mathrm{pH}$ value) but a strong dependence on the $\mathrm{pH}$, the other with a lower activity but active at acidic $\mathrm{pH}$ values (a). The (b) figure shows the theoretical reaction courses when the reaction was performed under a controlled $\mathrm{pH}$ value (solid line) or when the $\mathrm{pH}$ decreased along the reaction course (dashed line).

One condition that will always change during the process is the ratio between the concentrations of substrate and reaction product. Furthermore, in many instances, the enzymes may be inhibited by the reaction product [101-108]. That way, it is possible that one specific enzyme can exhibit an optimal performance in the absence of product or if the concentration of substrate is much higher than the concentration of the product, but it may suffer a strong inhibition due to its presence, stopping the reaction long before reaching the total modification of the substrate even when this may be thermodynamically feasible [109] (Figure 2). Therefore, it is possible that under industrial conditions, 
the optimal enzyme may not be the best enzyme under initial conditions, but an enzyme with a compromise solution offering good activity (but lower initial activity than the "optimal" enzyme) and low product inhibition, giving more linear reaction courses (Figure 2), may be desirable. In fact, the situation may be so complex that the best overall enzyme may be different depending on the initial substrate concentration utilized, the exact reaction conditions, etc. Again, it is possible that optimal reaction courses (more linear and reaching higher yields) may be obtained by mixing diverse enzymes presenting different kinetic features. Once again, we have not been able to find any paper using enzyme mixtures clearly addressed to solve this problem.

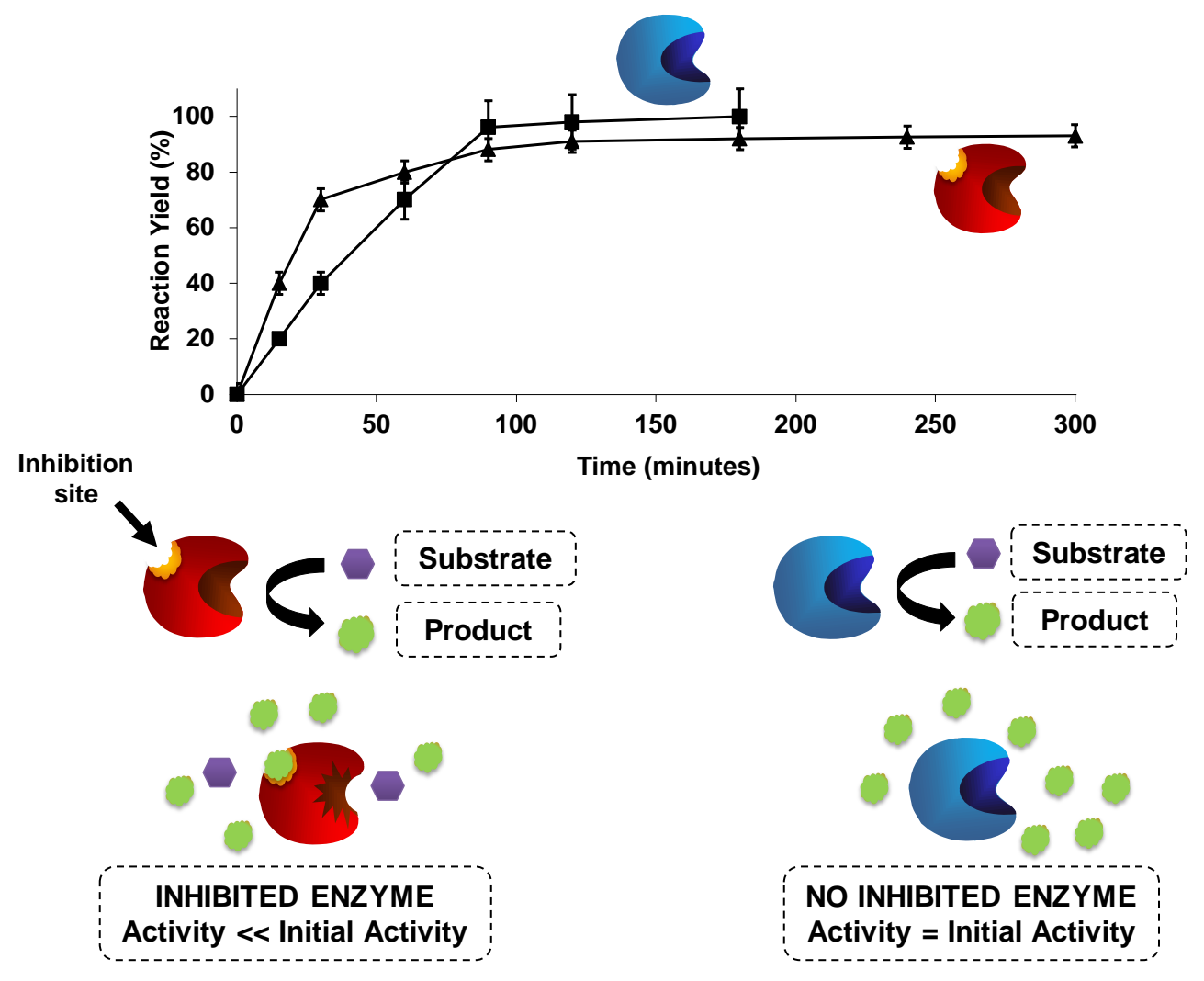

Figure 2. Effect of the product inhibition on the reaction courses using two hypothetic enzymes, one with a very high initial activity but showing a strong inhibition by the product, the other with a lower activity but without product inhibition.

It should be also considered that several changes in the reaction conditions may be simultaneously occurring, making it even more complex to find a really definitive optimal enzyme. However, the possibility of bearing in mind these changes along the reaction course is usually not considered in the selection of a biocatalyst for a specific process. In high-throughput screening, for example, which is normally used in directed evolution [110-112], analyzing the whole reaction course will add some difficulties in a screening that by definition must be very rapid [113-116]. That way, the selection of an optimal enzyme as catalyst for a specific process may not be as simple as it looks, and in some cases, it may be that there is no real "optimal" enzyme.

\subsubsection{Modification of Multifunctional Substrates}

There are many examples of homo-multifunctional substrates that are modified using biocatalytic approaches, such as polyhydroxy [117-128], polycarboxylic [129-131], and polyamine compounds $[132,133]$. In some instances, the researcher intends to partially modify the substrate in a selective way. Thus, a regioselective or enantioselective modification of the substrate is required [119,132-152] (Figure 3). 


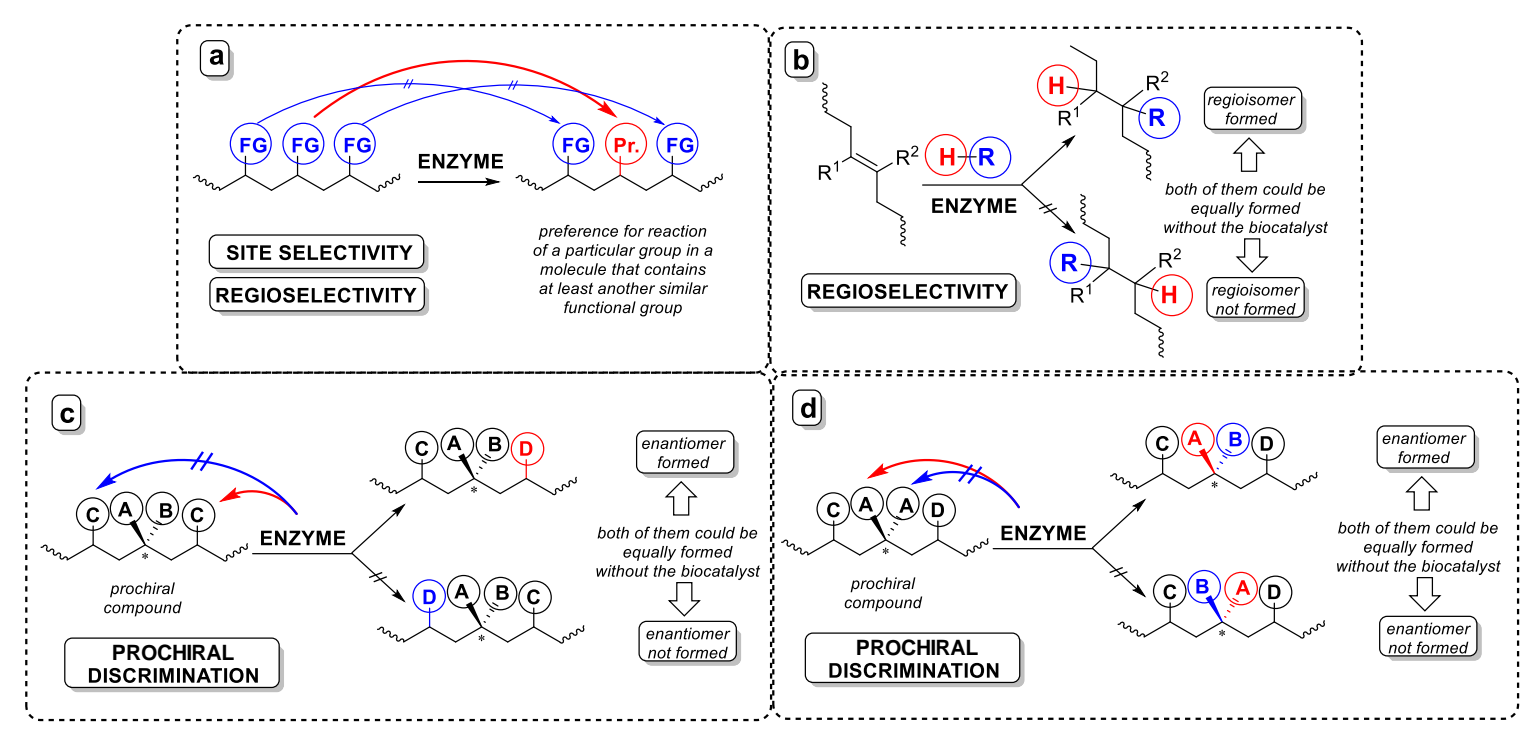

Figure 3. Schematic representation of enzymatic recognition capability for polyfunctional substrates: (a) regioselectivity (usually denoted as site selectivity) in transforming certain functional groups (FG, in blue) into a product (Pr in red) without altering others; (b) regioselectivity upon addition of an asymmetric reagent $(\mathrm{R}-\mathrm{H})$ to an asymmetric double bond; (c) prochiral discrimination by transforming only a functional group adjacent to the stereogenic center; (d) prochiral discrimination by transforming only a functional group directly attached to the pro-stereogenic center.

For these homo-multifunctional substrates, the term regioselectivity describes the preference for reaction of a particular atom or group in a molecule that contains at least one different atom or group of the same type (Figure 3a). This type of regioselectivity is often referred to as site selectivity, in order to distinguish it from the capability of forming one regioisomer mainly from the other upon addition to a multiple bond (Figure $3 b$ ). The capability of recognizing prochirality upon converting only one of the groups adjacent to the stereogenic center (Figure 3c) or only one of the functional groups attached to a pro-stereogenic center (Figure $3 \mathrm{~d}$ ) is also noteworthy, in each case leading mainly to one enantiomer versus the other. In this case, together with a good enzyme activity, it is necessary for the enzyme to present the desired selectivity to give the target product, and the desired specificity; that is, the ability to recognize the initial substrate but not the first reaction product and to stop the reaction at this point $[146,147,153-155]$. An enzyme with full regio- and enantioselectivity towards the desired product and unable to recognize this product as substrate (or as inhibitor) will be the one that will give the maximum yield of the target product with minimal contamination of byproducts (other reaction products formed by modification of the target product, initial substrate) (Figure 3).

If the full modification of the multifunctional substrate is the objective of the process, enzyme specificity becomes a problem as it can limit the recognition of some of the partially modified substrates or intermediate products (Figure 4) and that way, that enzyme will be unable to provide the desired full modification of the substrate, giving only a partial yield. The problems in the selection of the best enzyme to catalyze the reaction that have been discussed above for the monofunctional substrates remain in this instance, but now it is necessary to consider how the enzymes recognize the different intermediate products (mono-modified, di-modified, etc., and all in different positions) [146,147,153-155] (Figure 4). This may be very complex if the number of possible intermediate products is large. Moreover, in many instances the modification will not be random, and each enzyme may have a different route in the full modification of the substrate, depending on the enzyme selectivity and specificity (Figure 5). 

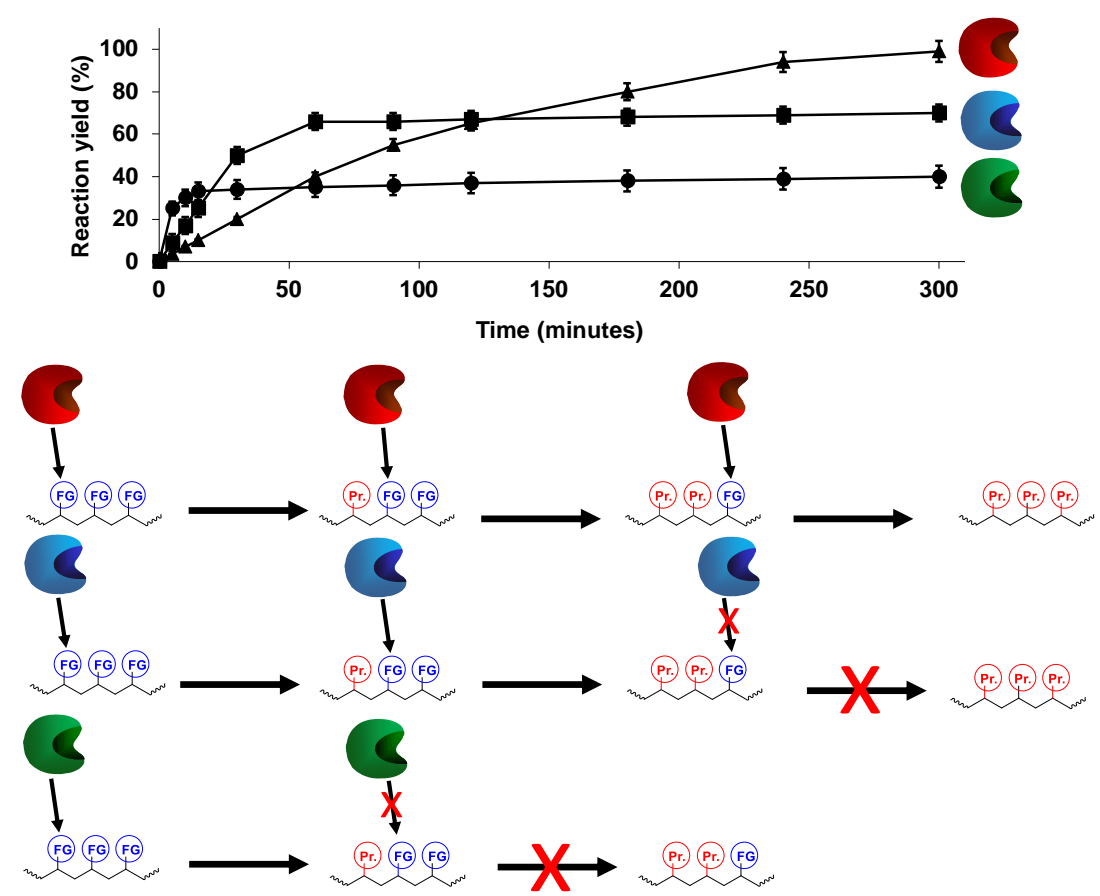

Figure 4. Effect of the enzyme activity (specificity) versus the different intermediate products in the modification of a trifunctional substrate. The figures show the expected reaction courses when a poorly active enzyme is able to recognize all intermediate products, or when the enzymes are unable to recognize some of these intermediate products, even being initially more active versus the initial substrate.
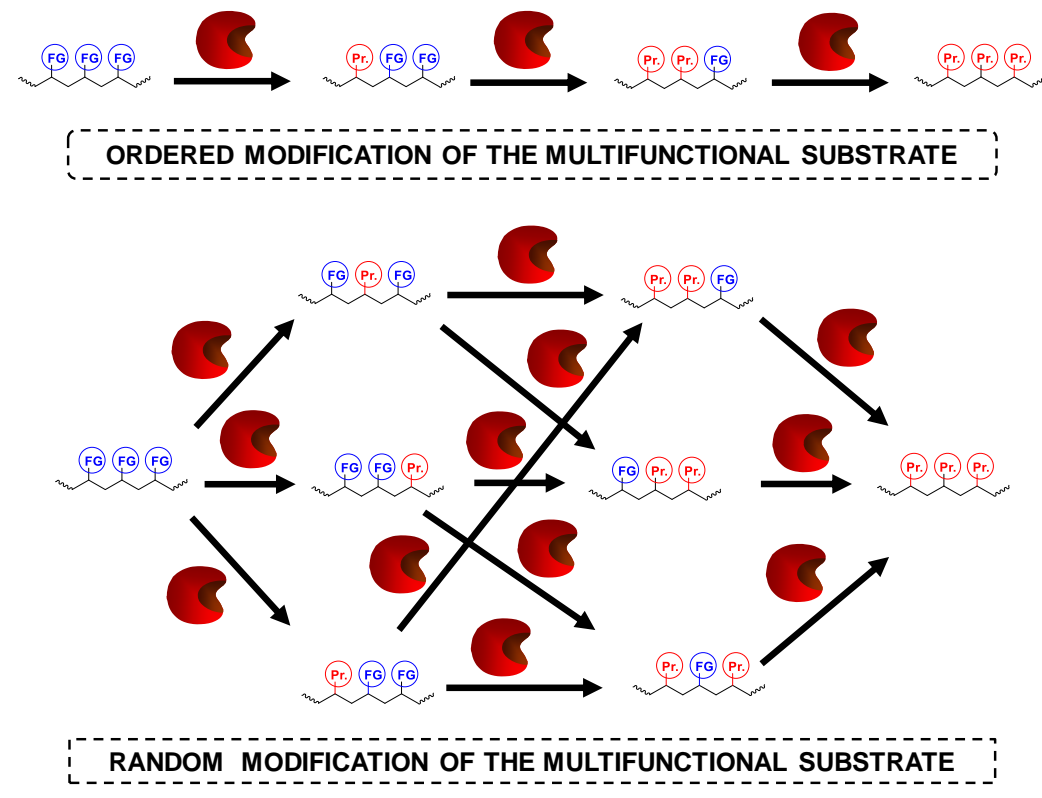

Figure 5. Ordered or random enzymatic modification of multifunctional substrate.

The difficulty in selecting an optimal biocatalyst may increase as it is possible that some enzymes that are not very suitable for the first modification of the starting substrate may be more active with progressively more extensively modified intermediate products [156-159]. The complexity of the catalysts selection may further increase if some of the intermediate products are chiral, as some enantiomers may not be recognized as substrates by some of the enzymes. In the most extreme cases, some of these intermediate products may behave as an inhibitor of the enzyme (Figure 6). 

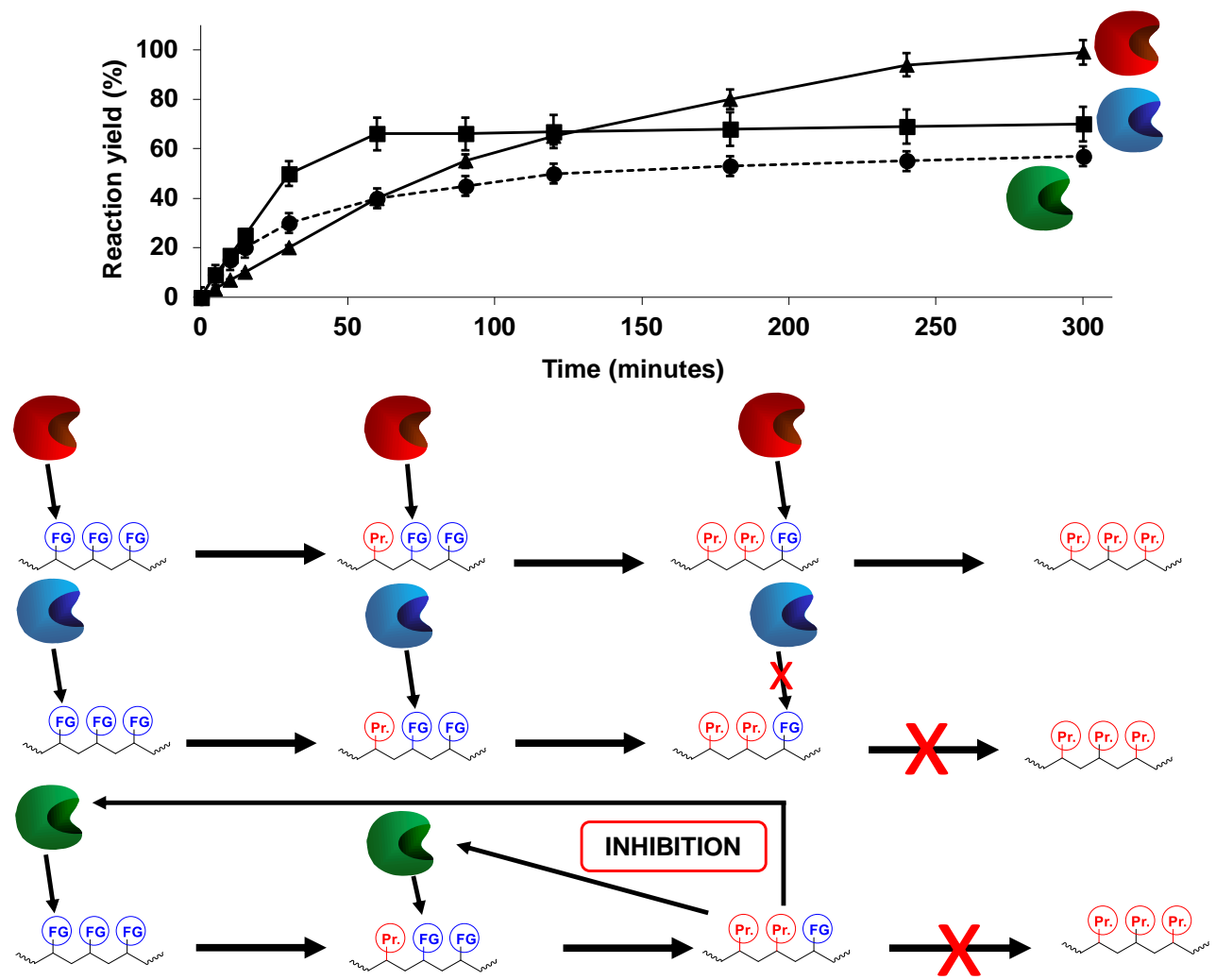

Figure 6. Effect of enzyme specificity and product inhibition in the reaction courses of modification of multifunctional substrates. The figure shows one very active enzyme that cannot hydrolyze the last intermediate product, other that is less active but recognize all intermediate products and a last enzyme that not only cannot modify the last intermediate product, but that is also inhibited by it.

That way, once again the use of only the initial reaction rates provides fully incomplete information to select the optimal enzyme to be used in the process, making it necessary to evaluate full reaction courses to really determine the best enzyme for this process. In these instances, the combined use of several enzymes may be the best solution, as that way it is possible to use enzymes able to optimally hydrolyze each of the likely intermediate products, permitting it to always reach $100 \%$ of the conversion yield, maintaining high reaction rates [160,161] (Figure 7).

\subsection{Lipases as Industrial Biocatalysts}

Lipases are one of the most used enzymes in industry $[9,79,81,162-164]$. They belong to the class of hydrolases (EC 3.1.1.1) and their natural function is the hydrolysis of triglycerides to fatty acids and glycerol. Nevertheless, under non-aqueous conditions, lipases are able to catalyze a broad range of reactions such as esterification, transesterification, and interesterification or acidolysis [165-177]. Moreover, besides this broad range of reactions, lipases are able to recognize a vast diversity of substrates, being able to catalyze even promiscuous reactions $[178,179]$.

This ability of lipases is perhaps based on their mechanism of action, called interfacial activation, makes the lipase active center very flexible $[180,181]$. The active center of most lipases is covered by a polypeptide chain called "lid". The internal side of the lid is hydrophobic, interacting with the hydrophobic area surrounding the active center and isolating it from the aqueous medium. In the presence of a hydrophobic surface, such as a drop of oil, the lid opens exposing the active center and its hydrophobic neighborhood and this lipase is adsorbed and stabilized on that surface [182]. Induction of interfacial activation is not limited to oil drops and lipases can be adsorbed via its open form on any hydrophobic surface such as hydrophobic proteins, other lipases and hydrophobic supports [81]. 
Based on their versatility, lipases have been used in several areas such as food industry for flavor enhancement, synthesis of flavor esters and emulsifiers, modification of fats and oils; chemical industries for synthesis of esters, detergents, emulsifiers, biofuels (biodiesel), wastewater treatment; and pharmaceutical and cosmetics industries for resolution of racemic mixtures, etc. [183-191].
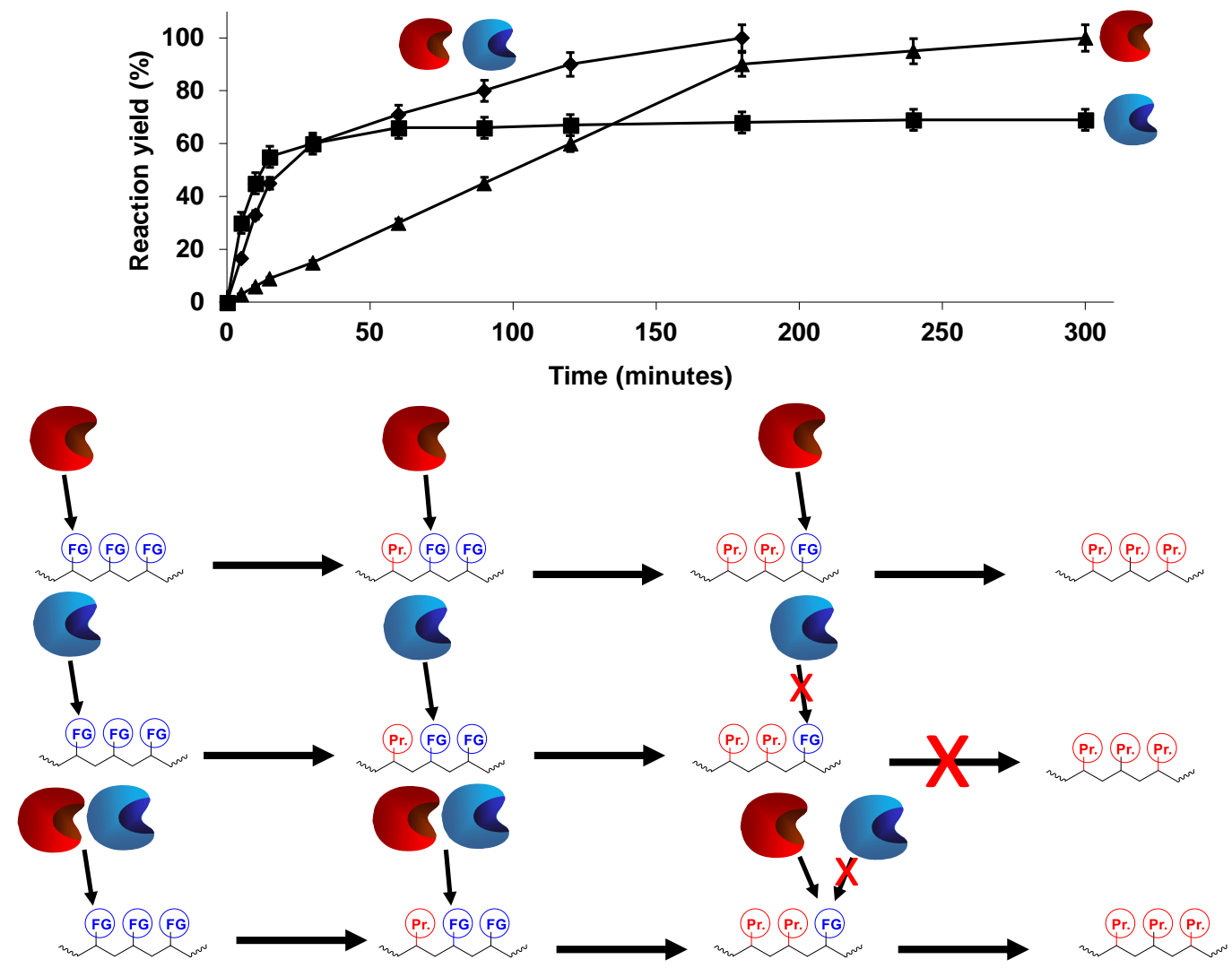

Figure 7. Solving the problem of product inhibition by using mixtures of several enzymes, one with high activity and high product inhibition, and the other with lower activity but not inhibited by the product.

\section{Oils and Fats as Heterogeneous Substrates}

Oils and fats are mainly composed of triglycerides, with some free fatty acids and very small amounts of mono and diglycerides. In this context, triglycerides may be considered as trifunctional and racemic (when presenting different acyl substituents) or prochiral substrates (when presenting monofunctional acyl substituents) (Figures 8 and 9) [192-195].

There are three ester bonds between glycerin and fatty acids. If the substituents in positions 1 and 3 are the same, they are prochiral substrates and after hydrolyzing position 1 or 3 an enantiomer of the diglyceride will be produced (Figure 8). If the substituents in these positions are different, they are already chiral substrates very likely in racemic form (Figure 9). That is, the lipase-catalyzed hydrolysis of a "pure" triglyceride may be initially a complex problem because the substrate may be a racemic mixture. Moreover, after the first modification, several diglycerides may be produced, having different enantiomers and regioisomers, and even free fatty acid composition (Figures 8 and 9). The final intermediate product, the monoglyceride, will have similar diversity in its composition (Figure 9). 


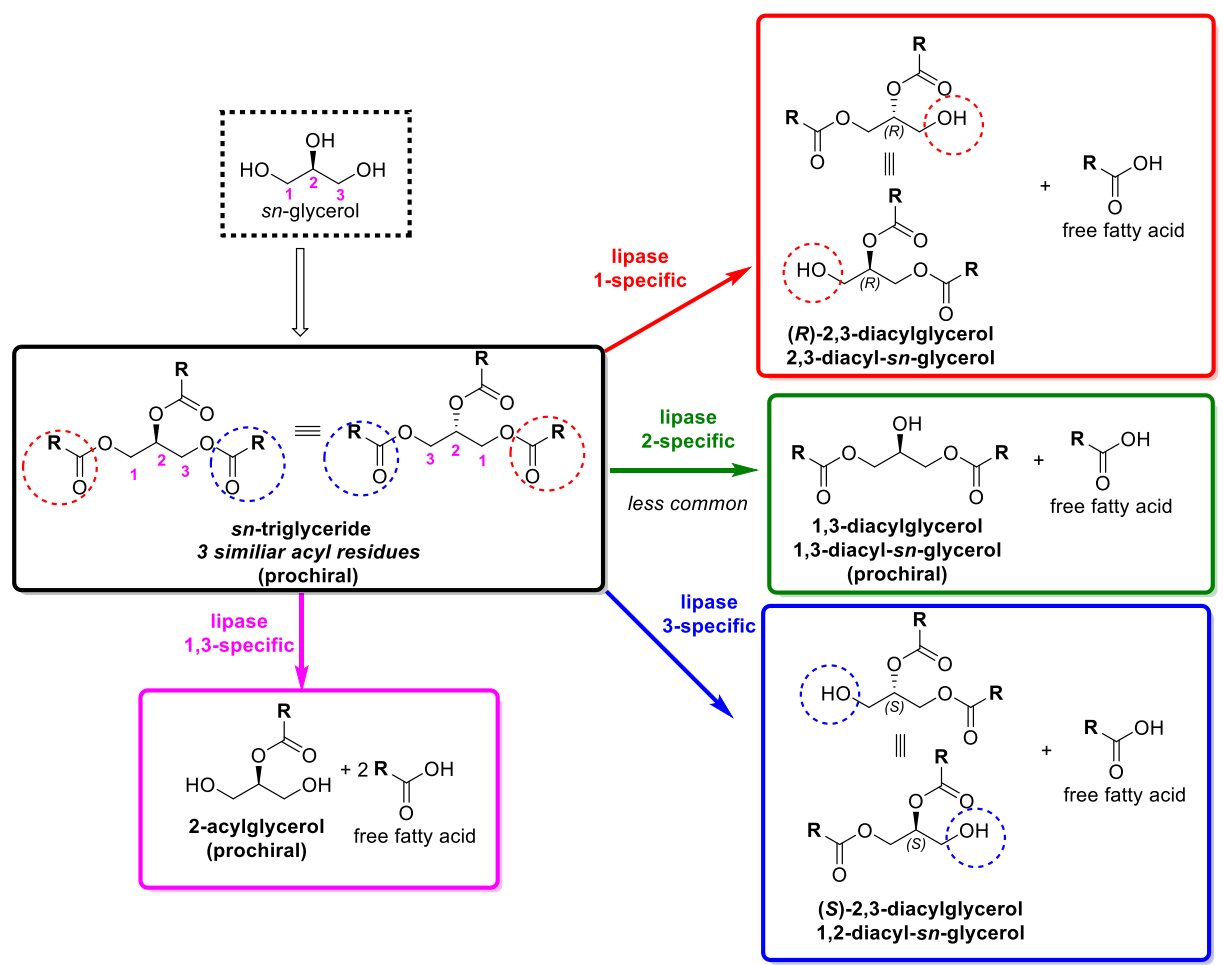

Figure 8. Diversity of reaction products in the first step of a lipase-catalyzed hydrolysis of a triglyceride possessing three identical acyl groups.

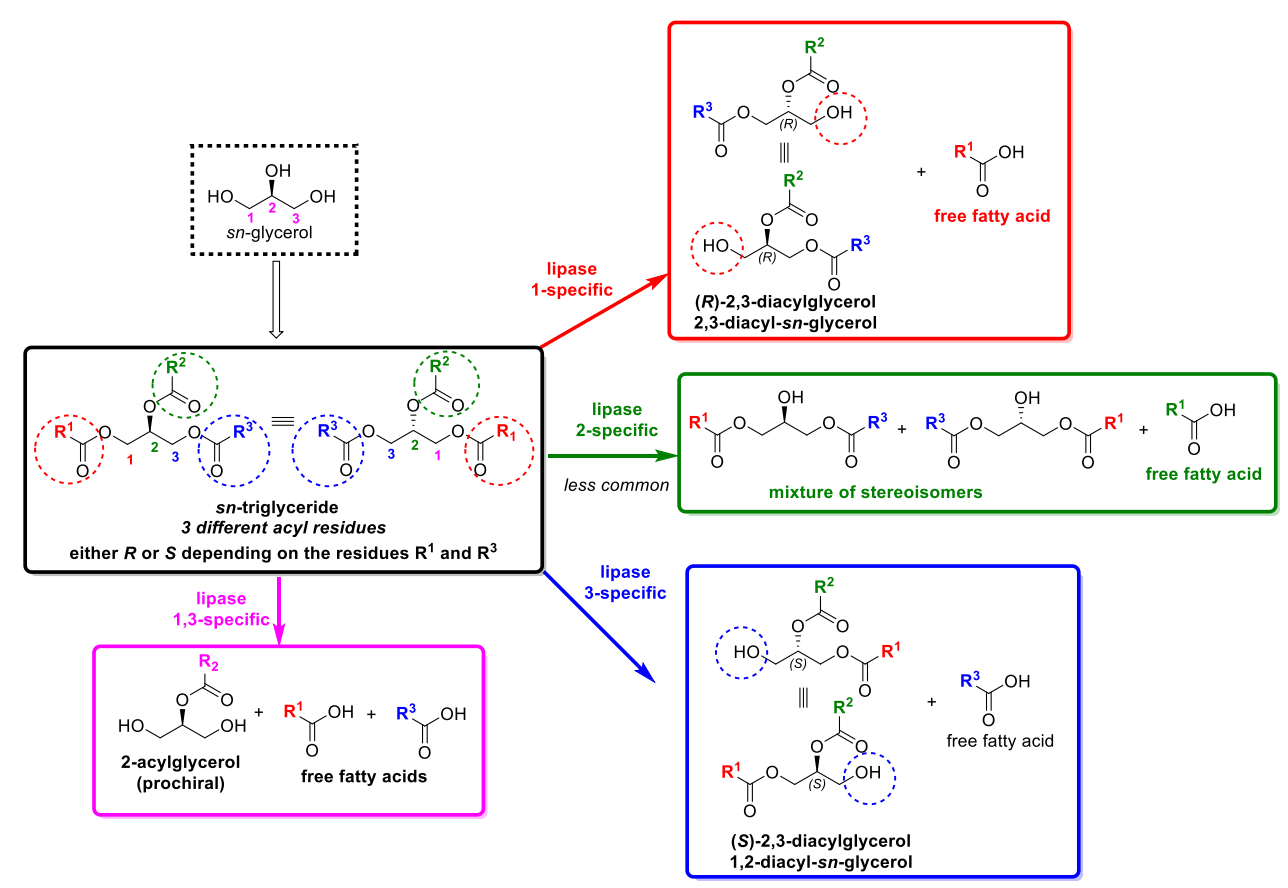

Figure 9. Diversity of reaction products in the first step of a lipase-catalyzed hydrolysis of a triglyceride possessing three different acyl residues (R1, R2 and R3), according to the lipase specificity (1-specific, 3-specific, 1,3-specific or 2-specific).

In some instances, the goal of the research is not the full hydrolysis of the triglyceride, but to release only specific fatty acids to produce enriched solutions of the remaining glycerides or the free fatty acids [153-155,196-198]. This is the case when the nourishing value of triacylglycerols is the key 
point, as this property depends not only on the fatty acid composition, but also on their positional distribution. Therefore, lipases can be very useful for the preparation of novel structured lipids, possessing improved dietary or functional properties, such as low-caloric triglycerides [199], or for the enrichment of triglycerides with $\omega-3$ poly-unsaturated fatty acids, such as eicosapentaenoic acid or docosahexaenoic acid [198,200-202].

In this case, enzyme specificity is the key for an optimal result, and the selection of the optimal enzyme will pursue the higher and faster accumulation of the target free fatty acid or the target glyceride [153-155,174,203-205].

However, a highly specific lipase becomes a serious problem when the objective is to have a full modification of this triglyceride, as the "substrate", even just the main substrate in each reaction stage (Figure 10) (triglyceride, diglyceride or monoglyceride), will be different; additionally, if it is a hydrolytic process, the $\mathrm{pH}$ may be changing during the process (Figure 1). That way, selecting an optimal lipase for the full modification using a pure triglyceride becomes very problematic. Full reaction courses using the target concentration of the substrate should be studied to select the most adequate enzyme for that reaction. In this respect, the most active on the original triglyceride under the initial reaction conditions may be fully unsuitable to modify some of the final monoglycerides under a more acidic $\mathrm{pH}$ value. As stated above, the situation is more complex if some of the intermediate products are not good substrates for the enzyme but are good inhibitors: both reaction rates and reaction yields will be decreased (Figure 6).

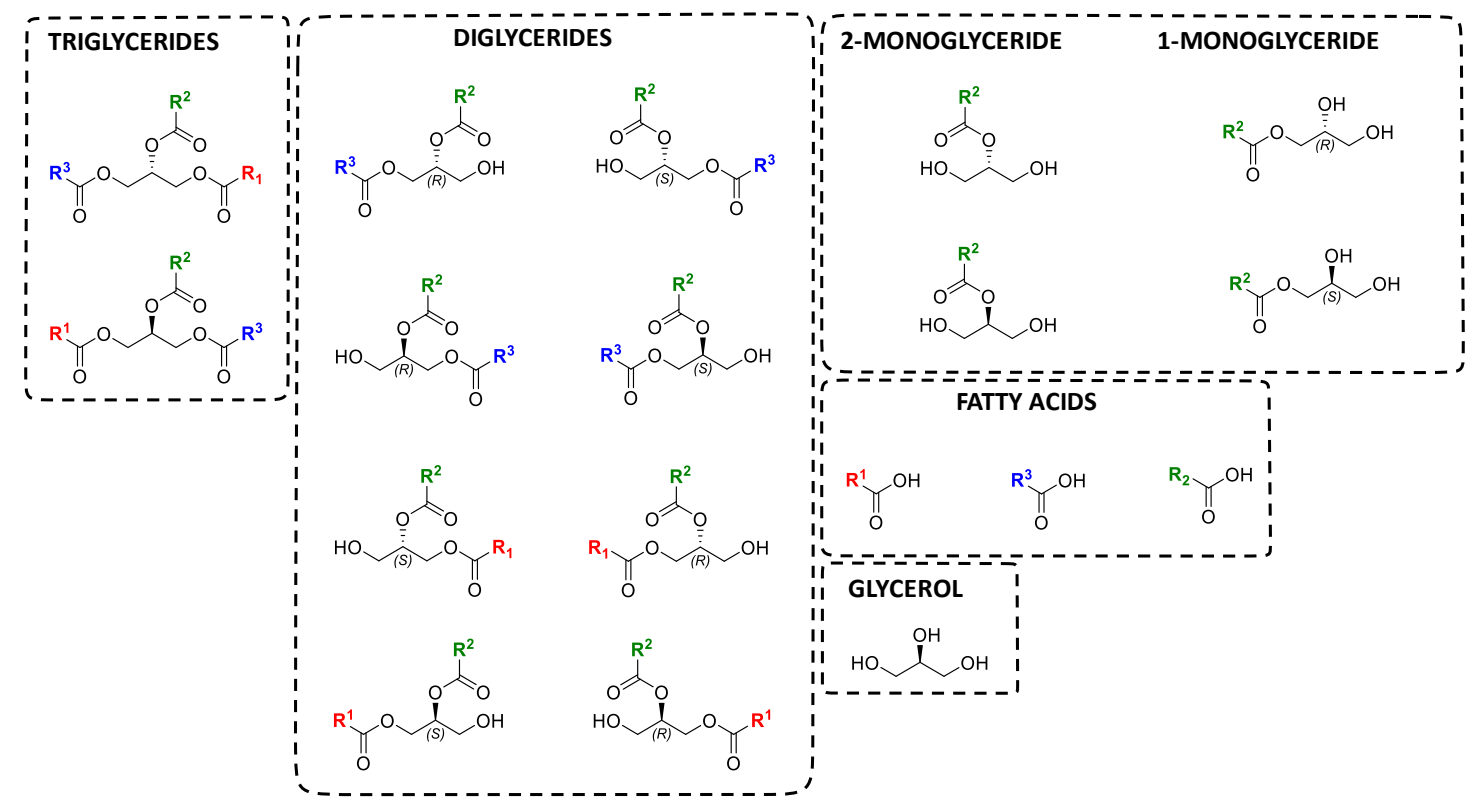

Figure 10. Different components of a reaction, including the intermediate products, when an oil is hydrolyzed.

Internal acyl migration is undoubtedly the main side reaction which can be found when the regiospecific synthesis of structural triglycerides is intended. In fact, this process induces serious complications for obtaining pure regioisomers, either diglycerides [206] or monoglycerides [207], through different acyl-transfer processes, mainly trans- or interesterifications. It is known that the acyl migration rate depends directly on the reaction temperature (the lower the temperature, the higher reaction time required) [208], the $\mathrm{pH}$ value [153,209], the water activity (probably affecting the activation energy of the reaction by modifying the charge distribution of the transition state [210-212]) and on the type of solvent used (generally, polar solvents are described to reduce acyl migrations [213]).

The mechanism of these acyl migrations has remained controversial, but recently Mao et al. [214] have published a very interesting study, applying quantum chemical models using density functional 
theory at the molecular level. With this computational technique, these authors compared two possible situations, non-catalyzed and lipase-catalyzed acyl migration. In the first case, they considered three different pathways-concerted, stepwise or stepwise including a water molecule, as shown in Figure 11-concluding that the last one, a stepwise pathway with the aid of water, shows lower activation energy for the rate-limiting step ( $31.7 \mathrm{kcal} / \mathrm{mol}$ for path (c) versus $41.8 \mathrm{kcal} / \mathrm{mol}$ for (b)), although in any case non-catalyzed migration will proceed extremely slowly. Interestingly, they observed how the lipase-catalyzed migration, depicted in Figure 12, was much faster than any of the non-catalyzed migration pathways, describing how the rate-limiting step (the last one) implicating a water molecule shows an activation energy of $18.8 \mathrm{kcal} / \mathrm{mol}$, which is very similar to the one $(17.8 \mathrm{kcal} / \mathrm{mol})$ experimentally measured [210].

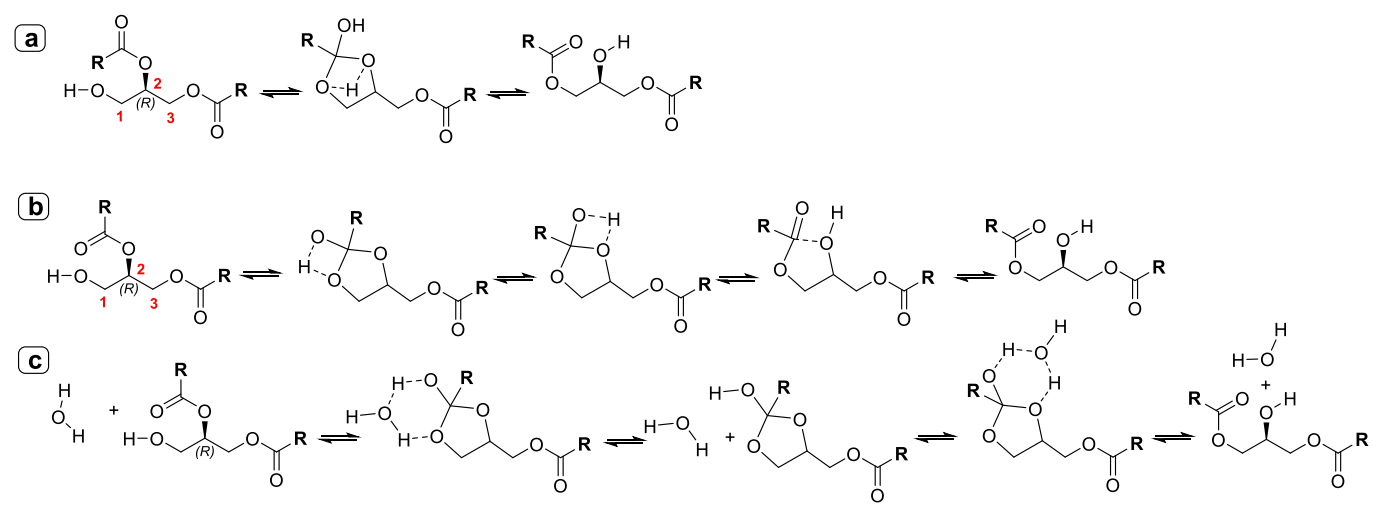

Figure 11. The possible mechanisms of acyl migration in the non-catalyzed mechanism (NCM) scheme: (a) concerted pathway; (b) stepwise pathway; (c) stepwise pathway with the aid of water (adapted from Mao et al. [214]).

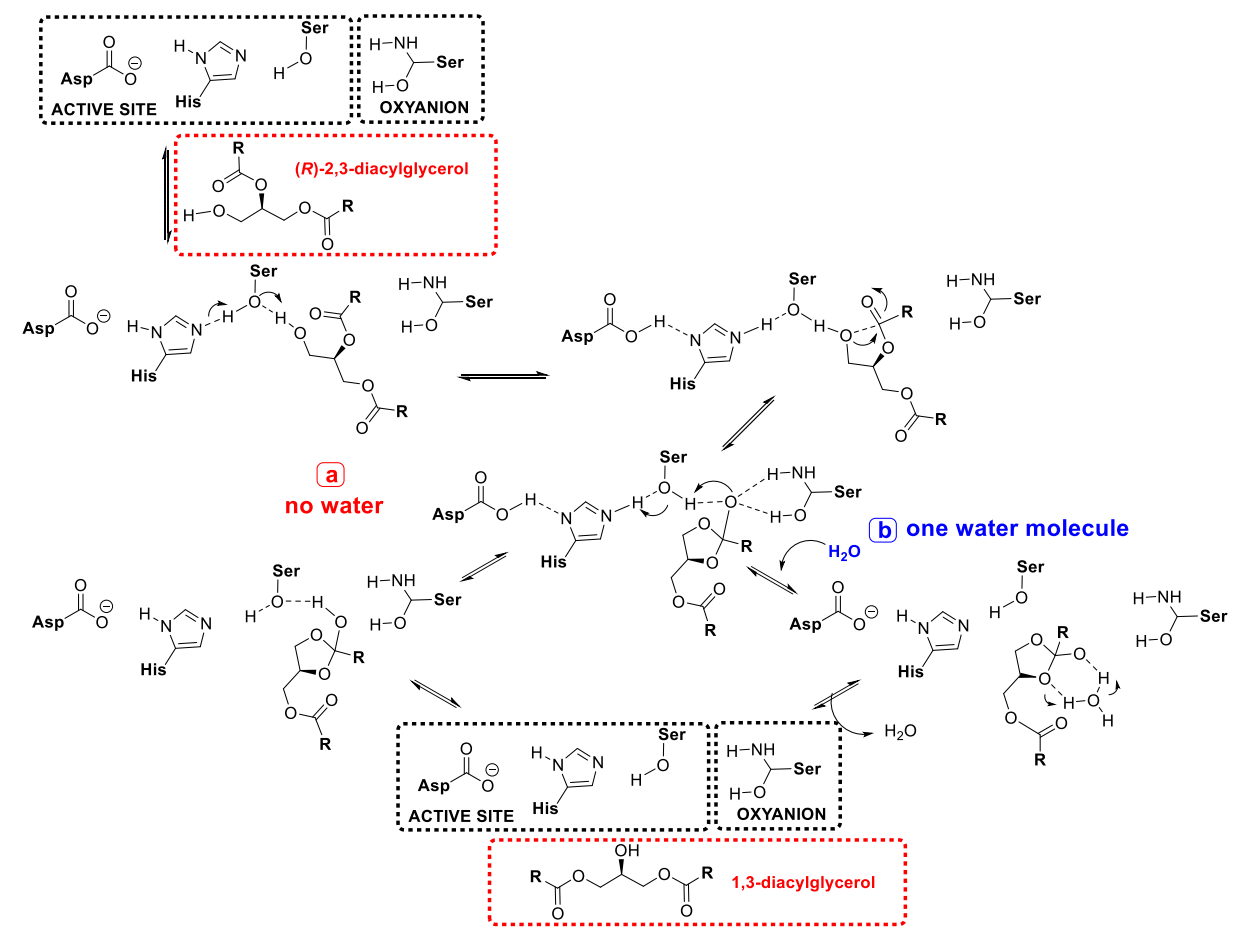

Figure 12. Postulated mechanisms of acyl migration in the lipase-catalyzed mechanism (LCM) scheme: (a) without and (b) with the aid of water (adapted from Mao et al. [214]).

Acyl migration is a problem when a regioselective reaction is intended, but if a full modification of a triglyceride is pursued, it becomes an advantage [215-219] (Figure 13). This may somehow mitigate 
the effects of enzyme specificity, as this permits that the enantio- or regioisomers presented in the reaction may be evolving during the reaction in a spontaneous way giving some isomers that may be good substrates for the enzyme, enabling that strict 1,3 regioselective lipases can fully modify the triglycerides $[215,220,221]$.

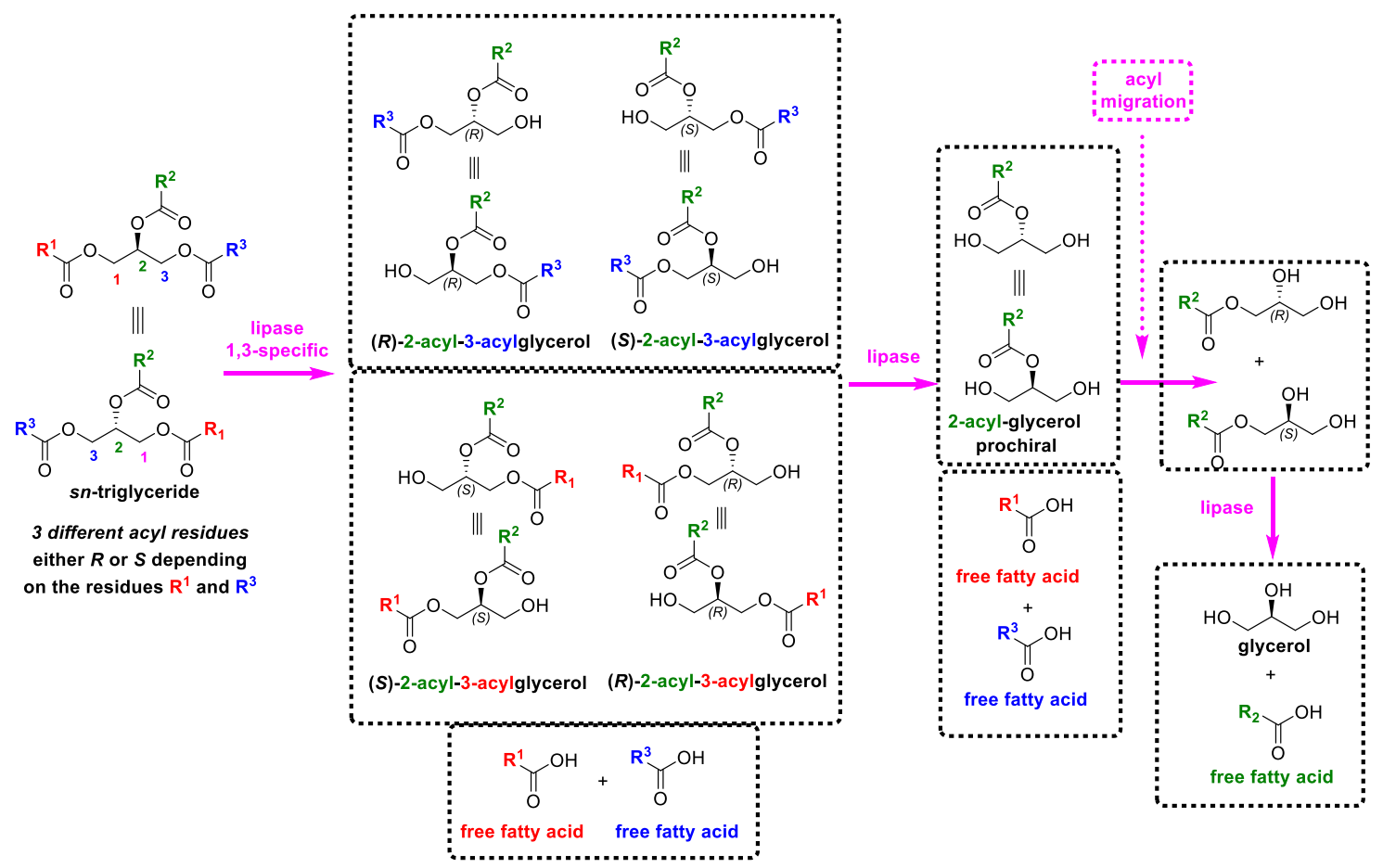

Figure 13. Full modification of triglycerides using a strict 1,3 lipase thanks to the acyl migration. The figure shows the diversity of reaction products in a 1,3-specific lipase-catalyzed hydrolysis of a model triglyceride; the first step will produce a complex mixture of regio- and stereoisomers of diglycerides, while the second hydrolytic step will furnish a prochiral 2-acylglycerol. This one, after a lipase-catalyzed acyl migration, will lead to a racemic mixture of chiral monoacylglycerol, which eventually could be hydrolyzed to glycerol.

Moreover, neither natural oils nor fats are composed of a single triglyceride, they present many different free fatty acids, in different positions and giving different enantiomers [222-225] (Figure 14). That way, being a collection of many different triglycerides, any oil or fat is in fact a very complex and heterogeneous substrate. If the situation to choose a single optimal lipase to modify just a pure triglyceride was complex, the fact that a natural oil may present dozens or hundreds of different triglycerides makes the situation very difficult [222-225]. The best lipase for the main components of the oil may be strongly inhibited by other triglycerides, or by some of the produced diglycerides or monoglycerides. Moreover, it may be that this lipase cannot recognize some of the free fatty acids attached to the glycerin, preventing it reaching full oil conversion. That way, the lipase that gives the best initial rates could not reach full oil modification or slow down the reaction in the final stages (Figures 4 and 6). Moreover, in oil hydrolysis reactions, the control of the $\mathrm{pH}$ is not possible using a titrating reagent [226-228]. The addition of a titration agent can promote the formation of soaps. That way, a decrease of the $\mathrm{pH}$ value is expected during the hydrolysis reaction (Figure 1). Again, the selection of the best lipase should consider the full reaction course and may be very hard to find a single enzyme that has the best properties in the whole process. 


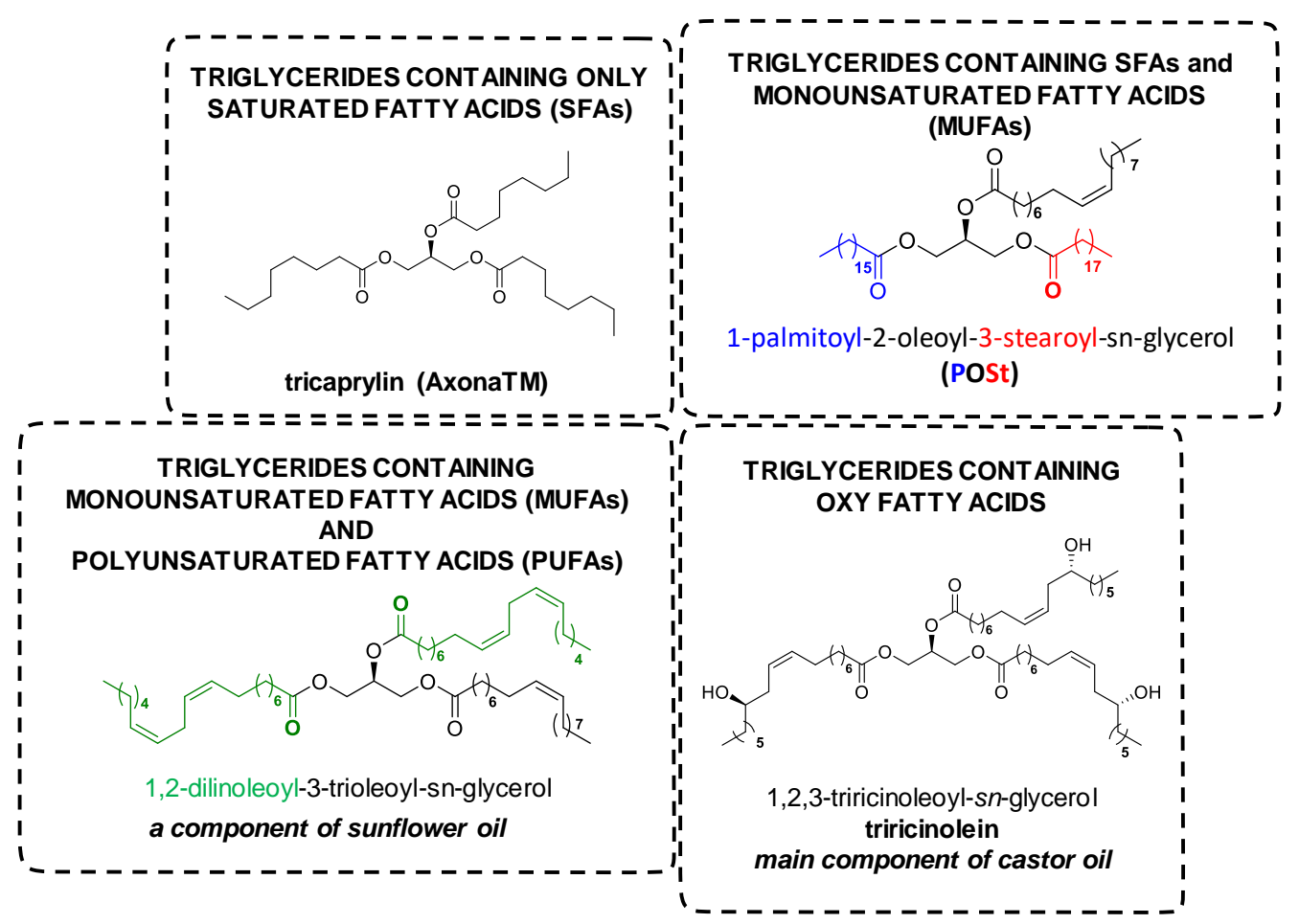

Figure 14. Some examples of the structural diversity of triglycerides.

There are two cases where the full modification of all the glycerides contained in an oil or fat is desired. These are the hydrolysis of the substrates to transform all glycerides in free fatty acids $[226,228]$ and the alcoholysis of the substrates to produce biodiesel [229-235].

\subsection{Lipase Production of Free Fatty Acids via Hydrolysis of Oils and Fats}

In oleochemistry, the main application of lipases is in the hydrolysis of vegetable oils to produce fatty acids $[226,236,237]$. Free fatty acids present a wide range of uses in food industry such as soap manufacturing or surfactants, and some biomedical applications $[226,236,237]$. The main chemical method of hydrolysis of fats and oils to produce fatty acids and glycerol involves high temperature and pressure presenting high yield. However, under these extreme conditions, oil and fatty acids polymerization and formation of byproducts occurs, resulting in dark fatty acids and colored aqueous glycerol solutions [238]. Instead, using lipases for this process results in energy saving and minimization of thermal degradation of substrates and products, where the unsaturated fatty acids can be produced without oxidation [239].

However, enzymatic hydrolysis presents the disadvantage of enzyme specificity compared to chemical hydrolysis. Conventional chemical processes produce the full hydrolysis of the triglycerides, while using the enzymatic technology the final yield is limited by the regioselectivity or the substrate specificity of the used lipase. For example, Candida rugosa lipase produced by submerged fermentation was used for the hydrolysis of sunflower oil, resulting at the highest yield 39.5\% of the original oil [240]. Fungal lipase from Aspergillus niger has been tested for castor oil hydrolysis and the best performance achieved was around $60 \%$ in $72 \mathrm{~h}$ [241].

Other problems that will decrease the full hydrolysis of oil by lipases are the production of mono and diglycerides and the inhibition caused by some of the fatty acids (Figures 2 and 6). The intermediate glycerides cannot be easily recognized by some lipases, while the accumulation of fatty acids in the reaction medium can produce product inhibition. Finally, during enzymatic oil hydrolysis, the reaction $\mathrm{pH}$ is generally uncontrolled to avoid saponification and some problems in the purification steps, being the final $\mathrm{pH}$ much more acid than the initial one. Thus, the reaction conditions will be heterogeneous and will be changing along the reaction course. Thus, it could be assumed that the full hydrolysis 
of these complex substrates, such as vegetable oils, could be better performed using a mixture of biocatalysts made up of different enzymes, with different specificities and activities [242] (Figure 6).

\subsection{Biodiesel Production Using Lipases as Biocatalysts}

\subsubsection{Transesterification}

Transesterification is the reaction between triglycerides (oils and fats) and alcohols to produce fatty acid alkyl esters and glycerol. When short chain alcohols are used, like methanol or ethanol, the resulting ester collection is called biodiesel $[173,243]$. Currently, the main synthetic approaches used for biodiesel production are alkaline-catalyzed and acid-catalyzed transesterification (with simultaneous esterification of free fatty acids) [244,245]. The technical issues associated with chemical transesterification, such as high energy requirements, difficult recovery of the catalyst and glycerol, and environment pollution, has attracted the interest towards the enzymatic process, using lipases as catalysts [246,247].

In the transesterification reaction catalyzed by lipases several factors affect the final reaction yield. First, the lipase source: fortunately there are lipases from very diverse origins, such as animal, plants and microbiological sources, and many of them have been tested in biodiesel production [246,248]. The main problem for each specific lipase is associated to the second factor in biodiesel production, which is the triglyceride source [249]. As mentioned before, oils and fats are very heterogeneous substrates (Figure 14). Therefore, lipase specificity will affect the enzyme activity over each substrate, thus, affecting the final reaction yield. For example, comparing soybean, sunflower and rice bran oils, and the three most used commercial immobilized lipases from Novozymes: Novozym 435 (an immobilized lipase B from Candida antarctica [250]); Lipozyme TL IM (an immobilized lipase from Thermomyces lanuginosus [251]) and Lipozyme RM IM (an immobilized lipase from Rhizomucor miehei $[252,253])$, the final yield changed for each lipase and each oil from $50 \%$ using Novozym 435 to 5\% using Lipozyme RM IM for sunflower oil [254].

Other aspects that change the final yield of lipase-catalyzed transesterification reactions are the alcohol source and the alcohol:oil molar ratio. As stated above, methanol and ethanol are the most used alcohols due to their low cost and the final properties of the produced ester as fuel. Nevertheless, some lipases are inhibited/inactivated by methanol or ethanol, and moreover, although the stoichiometric alcohol:oil molar ratio is 3:1, some excess of alcohol could be needed to displace the reaction towards the synthesis, as glycerin will remain in the medium as a competitor. In this case, the choice of alcohol, as well as the lipase source, can affect the achieved yield and reaction course [254-257].

The combination of different lipases in the reaction, as will be discussed later, is an interesting way to reduce the reaction time in enzymatic transesterification and increase the final yield allowing the full alcoholysis of the triglyceride (Figure 6).

\subsubsection{Hydroesterification}

Another possibility to produce biodiesel by an enzymatic route is using a strategy called hydroesterification. This process involves a two-step mechanism where, firstly, the tri-, di- and monoglycerides are hydrolyzed to produce free fatty acids and glycerol, and in the second step, the purified free fatty acids are esterified using an alcohol, such as methanol or ethanol [258-263].

The hydroesterification allows the use of any fatty raw material (e.g., vegetable and waste cooking oils, animal fat, acid waste from vegetable oil production) independently from its acidity and water content [249]. It promotes an advantage over the single step transesterification process, which inevitably generates soaps in the presence of fatty acids, inactivating the catalyst, and making it difficult to separate the biodiesel from the glycerol which is recovered at a high level of purity because of the absence of alcohol and salts in the aqueous phase.

Although many researches used immobilized lipases for hydroesterification, recently, the use of liquid lipases has gained popularity $[235,264-266]$. The use of a liquid lipase instead of an immobilized 
lipase implies the presence of water in the process, thus, related to the first hydrolytic step. Moreover, water promotes alcohol dilution in the medium, reducing its denaturing effect on the enzyme and leading to the formation of a second liquid phase in the reaction, creating a hydrophobic interface that is known to activate many lipases [235,264-266].

\section{Advantages of the Simultaneous Use of Several Lipases to Fully Modify Multifunctional Substrates: The Concept of Combilipases}

In Section 2 of this review, the difficulties in finding a single lipase that can have optimal properties in the whole reaction course of multifunctional and heterogeneous substrates [222-225], such as oils or fats, has been outlined; enzyme specificity, a feature in many instances critical to preferring biocatalysis over conventional catalysis in many processes, becomes a problem in this instance. It is possible that conversion yields may be well under the thermodynamics of the process if the enzyme is unable to modify some of the initial glycerides or intermediate products (Figures 4 and 6). Moreover, it is very likely that the reaction rate may be much lower than the expected one in the final steps of the reaction, if the activity of the enzyme is not adequate versus some of the remaining glycerides in the reaction mixture or are strong inhibitors of the enzyme (Figures 2, 4 and 6). Some authors, utilizing the lipase regioselectivity to get just a partial modification of the triglycerides, propose the enzymatic production of a biodiesel-like product, called ecodiesel, containing esters of the free fatty acids and monoglycerides [267-272].

Considering the problems for the full modification of oils, the researchers have proposed the use of a mixture of several enzymes to catalyze these reactions as a solution $[160,161]$. These lipase mixtures have been named combilipases [242]. Although these combilipases may also have advantages in the modification of monofunctional substrates (as previously discussed) (Figures 1, 2, 4 and 6), we have found very few studies using combilipases apart from oil modification. However, we have found many examples using combilipases in full hydrolysis [242] or alcoholysis [273] of fats or oils. The way combilipases have been utilized includes: mixtures of free enzymes, mixtures of individually immobilized lipases, or coimmobilized lipases. Next, some examples will be detailed.

\section{Use of Lipases from Microorganisms that Produce Several Lipases}

Some microorganisms naturally produce several lipase forms, or produce some lipase modifications (e.g., glycosylation) that can alter the final lipase properties in a heterogeneous way. It should be stressed that lipase features may be easily altered by very small modifications. In many instances, the enzymes are commercialized in the form of these lipase mixtures. Examples of lipase sources producing diverse lipases are Candida rugosa [274-276], Geotrichum candidum [277,278], Staphylococcus warneri [279], Penicillium simplissicimum [280], and Aspergillus niger [281]. Porcine pancreatic extract presents also several lipase forms [282]. These lipase extracts have been used in some instances to produce biodiesel or free fatty acids. In these cases, the mixture of the different lipases has been used $[280,283]$. In some instances, this may be done on purpose; in some other cases the situation may be just by chance, due to the lack of knowledge on the existence of different lipase forms [284,285] (in some cases, some of the lipases may be presented in traces and remain unknown to the researcher) [286]. In these cases, the study took advantage of mixing enzymes with different features, but the amount and proportion of each of them may not be easy to alter and it would be a chance if the enzymes ratio is the optimal one in the studied process. The situation may be somehow similar to the use of commercial enzymes cocktails of some enzymes in cascade reactions, like glycosidases [287-292]. The research cannot easily alter the composition of it. 
One option to control this phenomenon is to fraction all the lipase components. However, this may be too tedious and complex, although in some instances lipase fractioning may be achieved by the successive adsorption of the lipase extract on hydrophobic supports with different hydrophobicity [284,293-295]. In any case, it may be simpler to use lipases from different sources already in an isolated form than to purify and mix again the different components of a crude lipase extract, as there are no guarantees regarding the suitability of the mixture of the lipase fractions for the specific process that is under study. It is better to select lipases with the desired specificity properties than to use a natural mix of lipases crude extract. In most instances, even the researchers using these enzymes do not try to explain the results by the existence of several lipases forms.

Another possibility may be the control of the expression of one lipase and not the others, like in the case of G. candidum, which produces several lipases as a function of the free fatty acids used as lipase inducers [296].

Nevertheless, there are no systematic studies on how the changes of the lipases ratio forms alters the results in the use of these enzymes in the production of free fatty acids or biodiesel. That way, after drawing the attention to this possibility, we will not review this uncontrolled combilipase type.

\section{Use of Lipases Mixtures in Liquid Formulations}

In biodiesel production, there is a certain increase of the interest in using free enzymes as catalysts for this process $[235,265,266,297-305]$. This interest is based on the low prices of the lipases commercialized for this use and in the launching of new lipases specially commercialized for biodiesel production in liquid formulation (e.g., Eversa Transform launched by Novozymes) [306-308]. Moreover, in many instances the use of unsuitable supports raises problems that may be avoided using liquid formulations. In the synthesis of biodiesel, for example, Marty and coworkers have shown in many instances that glycerin (and water) can accumulate in the support producing an enzyme inhibition or inactivation [309-312]. Although this can be solved using very hydrophobic supports [309,313-315] or ultrasounds that can stir the biocatalyst particle from the inside and prevent the glycerin/water phase formation [316-318], some authors prefer to fully avoid the use of immobilized enzymes. In many instances, due to the non-aqueous nature of the medium, the enzymes will be used as aggregates [319-322] (that is, the problem of water/glycerin phase in the biocatalysts particle is not fully avoided, and enzyme aggregates may be hard to reproduce).

In the hydrolysis of oils, the use of inadequate immobilization systems may be also problematic. This reaction produced fatty acids, monoglycerides and diglycerides, with detergent-like and/or anion nature properties. They can promote the release of the enzyme from the supports when the employed immobilization strategy is the physical immobilization. This is the simplest enzyme immobilization strategy to produce an immobilized enzyme biocatalyst [323-325]. This may be solved using intermolecular crosslinking strategies or heterofunctional supports [81,326,327].

In aqueous media, lipases may have a tendency to form lipase-lipase aggregates [328-331], or be adsorbed on any hydrophobic molecule of the crude protein solution [295,332]; however, the presence of oil drops and all the detergent-like products should greatly reduce the risks of this enzyme aggregation (Figure 15). In any case, immobilization will be advantageous for a simpler enzyme reuse and a general improvement of the enzyme features [60-63]. Nevertheless, there are many examples of using combilipases in liquid form for both applications. 


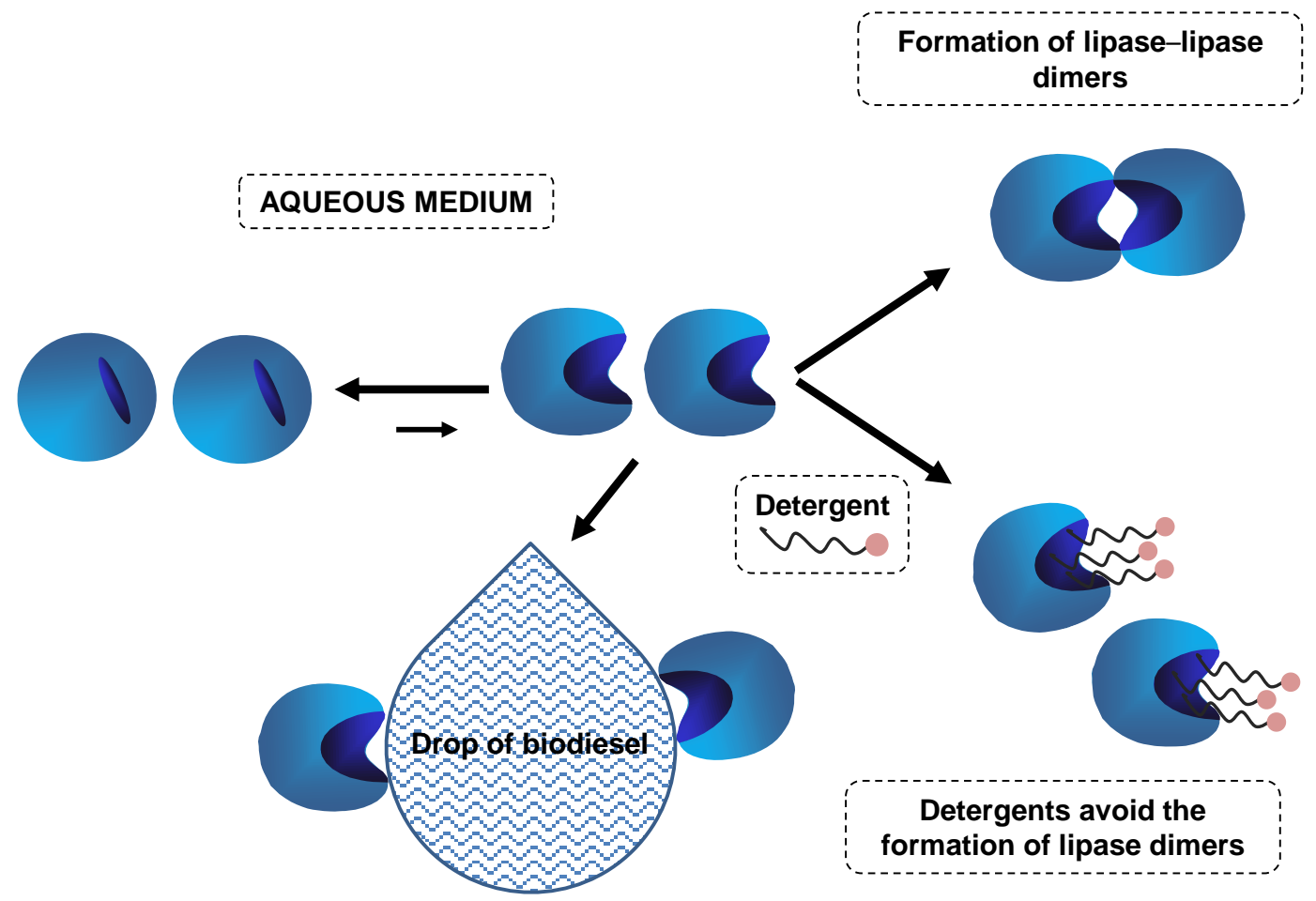

Figure 15. The tendency of lipase to give lipase-lipase dimers may be avoided by the addition of detergents or the interfacial activation on drops of biodiesel.

\subsection{Hydrolysis of Oils and Fats Using Combilipases in Liquid Form}

In a first example, lipase $\mathrm{D}$ from Rhizopus delemar, lipase $\mathrm{N}$ from Rhizopus niveus and lipase $\mathrm{G}$ from Penicillium sp. were used in the hydrolysis of soybean oil. These enzymes, not used in combination, gave free fatty production yields of $44 \%, 42 \%$ and $7.2 \%$, respectively, after $10 \mathrm{~h}$ [333]. The authors showed that the use of combilipases formed by lipases $G$ and $N$ or lipases $G$ and $D$, permitted to reach a hydrolysis yield of $95 \%-98 \%$ under similar conditions. This occurred even though lipase $\mathrm{G}$ was the least effective enzyme in the process [333], suggesting that it was able to eliminate some glyceride that could reduce the reaction rate for more efficient enzymes $\mathrm{D}$ and $\mathrm{N}$.

More recently, lipases from different $A$. niger strains (named A, B, C and D) were used in the hydrolysis of soybean oil [334]. This way, different forms of the lipase produced by the fungus could be obtained and assayed in this reaction. After optimization by a three-factor mixture design and triangular surface, it was decided that a combilipase using $31.2 \%$ of lipase B and $68.8 \%$ of lipase D exhibited the optimal properties in this reaction, indicating a synergistic effect of the combilipases. This was attributed to the different fatty acid specificities of the two lipases (Figures 4 and 6), although different $\mathrm{pH}$ activity/stability profiles could be also relevant [334] (Figure 1). Again, initial reaction rates of lipase B were significantly lower than the activity of lipase D. Curiously, the mixture of lipases $A$ and $B$ gave lower reaction rates than the individual enzymes, suggesting a mutual inhibition of some of the reaction products of each enzyme [334].

In a previous paper, lard has been hydrolyzed as a source of free fatty acids using the lipases from R. miehei and Penicillium cyclopium [335]. Using the lipases in an individual way enabled a hydrolysis reaction yield of $39.9 \%$ using the lipase from $R$. miehei, while the lipase from P. cyclopium gave a yield of only $8.5 \%$. The use of a combilipase of both enzymes permitted to reach a yield of $78.1 \%$. If this was assisted with $5 \mathrm{~min}$ ultrasound treatment before the reaction started, reaction yields became $97 \%$ [335]. This exemplified again how the use of two lipases, even if one of them was much less effective in the overall reaction than the other, may be a very interesting way to improve the reaction performance, based on the combination of enzymes specificities. 


\subsection{Use of Combilipases in Liquid Form in Biodiesel Production}

In a first report, lipases from R. miehei and P. cyclopium (expressed in Pichia pastoris) were utilized to catalyze the methanolysis of soybean oil in aqueous medium [336]. The lipase from R. miehei yielded $68.5 \%$ of biodiesel conversion, but when supplemented with lipase from P. cyclopium, the yields were above 95\%. Again, this effect was explained by the use of lipases with different specificities. In another paper, a very "complex" combilipase has been used to produce biodiesel from nonedible oils adding methanol in a stepwise way to prevent enzyme inactivation. [337]. The authors mixed lipases from Candida rugosa, Pseudomonas cepacia, Rhizopus oryzae and porcine pancreas type II, together with Novozym 435. This permitted it to reach conversion yields of $93 \%$ that were improved to $97 \%$ by adding $10 \mathrm{wt} \%$ of silica gel to eliminate water from the system. However, they did not compare the results with individual lipases or less complex combilipases. In another paper, rapeseed oil deodorizer distillates were used as raw material to produce biodiesel using lipases from C. rugosa and R. oryzae, giving $92.63 \%$ after $30 \mathrm{~h}$ and $94.36 \%$ after $9 \mathrm{~h}$ of reaction, respectively [338]. The use of a mixture of both enzymes increased the biodiesel yield to $98.16 \%$ in $6 \mathrm{~h}$ (after optimization via response surface methodology). Another study shows how an oil rich in phospholipids and free fatty acids from Chlamydomonas sp. JSC4 (a microalgae) were used to produce biodiesel [339]. A combilipase mixing lipases from Candida cylindracea and T. lanuginosus lipase gave a high yield (over 95\%). Yields were similar to those obtained using a lipase from Fusarium heterosporum expressed in Aspergillus oryzae and used as a whole-cell biocatalyst, but the reusability of this last was higher.

Phospholipids may be a problem in biodiesel production, for this reason a degumming step using a phospholipase is used in many instances. In a first example, the reactions were performed in two steps, degumming and transesterification, using crude canola oil [340]. In the first step, degumming was performed using phospholipase A2 reducing the phospholipid content 60-fold. In the second step, lipases of $R$. oryzae and C. rugosa were utilized to produce biodiesel. Using the individual enzymes, the yields were $68.56 \%$ and $70.15 \%$, respectively. Using a 1:1 mixture of these enzymes, the yield increased to $84.25 \%$ [340]. In another paper, both degumming and biodiesel production reactions were performed in just one pot, using a combilipase composed of lipase and phospholipase. The researchers utilized crude soybean oil, which also requires an additional pretreatment for gums removal if it is utilized for biodiesel production [341]. The authors proposed using combilipases mixing a lipase (Callera Trans L), two phospholipases (phospholipase A1 Lecitase Ultra and phospholipase C Purifine) and a lyso-phospholipase, achieving the degumming and transesterification in a single pot. The yield of biodiesel was higher than $95 \%$, avoiding the inhibitions caused by the phospholipids and converting part of the phospholipids into biodiesel, and the phosphorus content was lowered from $900 \mathrm{ppm}$ to $<5$ ppm [341]. In another paper, the lipase AY from C. rugosa was selected among six lipases by their high activity, and utilized in biodiesel production, but it only gave $21.1 \%$ biodiesel yield from oil containing phospholipids [342]. The combination of this lipase with some of the other lipases was assayed, and the best solution was the combination with Callera Trans L. Optimizing the methanol stepwise addition yielded more than 95\% biodiesel in $6 \mathrm{~h}$.

\subsection{Other Uses of Combilipases in Liquid Formulations}

In some instances, the objective of using combilipases is not the production of biodiesel or free fatty acids, but to produce special triglycerides. During the process, the nucleophile substrate will be changing, at the start it will be glycerin, then monoglycerides, later diglycerides, to finally get the target product, the triglyceride. That way, the production of these complex triglycerides may be carried out using combilipases.

For example, triglycerides were produced via esterification of glycerin and a concentrate of enriched conjugated linoleic acid using the lipases from Alcaligenes sp., Penicillium camembertii and R. miehei [343]. Using only the lipase from R. miehei, yields were just under $65 \%$. The lipases from Alcaligenes sp. and P. camembertii alone gave yields of only $3 \%$. However, the combined use of both enzymes permitted it to obtain a yield of $83 \%$. Moreover, the combined use of the lipase from R. miehei 
and lipase from Alcaligenes $s p$. permitted it to obtain a yield of $82 \%$ and the reactions proceeded three times faster than when using the lipase from $R$. miehei alone [343].

When the aim of the process is to stop the reaction in an intermediate state, using mixtures of lipases may be risky. However, considering the heterogeneity of oils, even in this situation the use of a mixture of lipases may be advantageous and could enable a higher yield, if the enzymes activities versus the target intermedium product are low. For example, a study was intended to produce monoglycerides via glycerolysis of beef tallow or palm oil [344]. Many commercial enzymes were assayed, but in the context of this review we will remark that a mixture of lipases from P. camembertii and Humicola lanuginosa gave a yield of approximately $70 \mathrm{wt} \%$ monoglyceride, more than either enzyme alone. However, the mixture of lipases from P. camembertii and Ps. fluorescens or R. miehei gave similar values to the ones obtained employing individually the lipases from Ps. fluorescens or R. miehei [344].

The use of mixtures of lipases to get specific structured lipids may not be a good idea, but in order to get a general mixture modification between two oils again may be beneficial by combining different specificities. In an example of this research, lipases from Rhizopus sp. and Lipozyme TL IM were utilized in individual form or as a mixture in the interesterification between Amazonian patauá oil and palm stearin [345]. This reaction is quite complex, as it involves the hydrolysis of both oils and the further esterification of the released fatty acids to the glycerides, expecting the interchange of the free fatty acids in the final triglycerides [346-349]. The lipase from Rhizopus sp. modified the sn-1,3 positions of the triacylglycerol, yielding an oil richer in saturated fatty acids in the sn-2 position. The lipase from T. lanuginosus showed no regioselectivity in this reaction, there was no alteration in the distribution of unsaturated and saturated fatty acids in the triacylglycerol, there was only a replacement of fatty acids at the same position in both oils. The use of both enzymes showed the combination of both situations, but no synergetic effects were detected [345,349].

\section{Use of Individually Immobilized Lipases}

In most industrial applications, enzymes must be immobilized to facilitate their recovery and reuse [350,351]. This was the first objective of enzyme heterogenization, as enzymes were initially quite expensive biocatalysts. The decrease in the price of enzymes (very clear in the area of lipases) makes this initial objective not so necessary at present. In fact, Novozymes has launched some new lipase products recommending its use in non-immobilized form to save the enzyme immobilization costs, as for example Eversa Transform catalyst to be used in biodiesel production [306-308]. Other authors remarked the possibilities of using free lipases in these reactions [235,265,266,297-305]. However, a proper immobilization may have more additional advantages than just facilitating enzyme recovery, and even more so in the case of lipases [60-63,352-356]. A proper immobilization may increase enzyme stability by rigidifying the enzyme structure, by partitioning deleterious compounds from the enzyme environment, or by stabilizing a more favorable enzyme conformation of the lipase. Moreover, lipase immobilization may improve enzyme activity for different reasons, e.g., by producing more active lipase forms, by avoiding enzyme distortion under harsh conditions if the immobilization has provided some enzyme structural rigidification, or by reducing enzyme inhibition [62] (Figure 16).

Immobilization may also alter lipase selectivity or specificity or produce enzyme purification [60-63,352-356] (Figures 17 and 18). That is, enzyme immobilization may be advantageous by very different reasons. Moreover, even if enzyme disposal may be economically feasible after just one reaction cycle, free lipases, as interfacially active molecules, can give rise to some problems in the purification steps, e.g., stabilizing emulsion of hydrophobic substances [357] (Figure 15). That is, even if the costs of the enzyme loss may be economically acceptable, the advantages of a proper enzyme immobilization may be too relevant to discard this powerful tool to improve the enzyme. This great potential of enzyme immobilization has promoted the continuous growth in the number of scientific publications in this apparently old-fashioned topic $[64,358]$. 


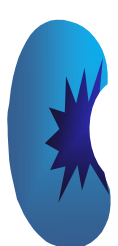

DISTORTED ENZYME

STRUCTURE

Activity $\ll$ Initial Activity
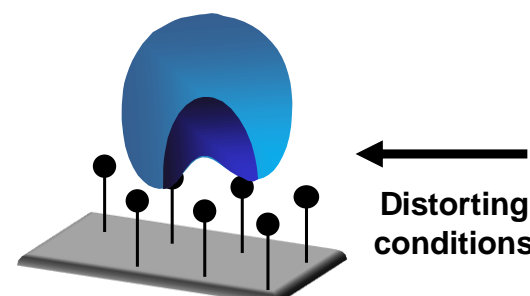
conditions

\section{LOWER ENZYME DISTORTION}

Activity $=$ Initial Activity
Inhibition

site

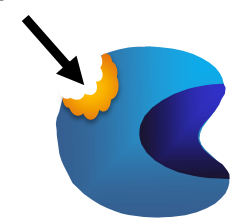

SOLUBLE FORM

INHIBITED ENZYME

Activity $\ll$ Initial Activity

Figure 16. Effect of the stabilization of the enzyme after immobilization on enzyme activity in the presence of inhibitors or distorting conditions.

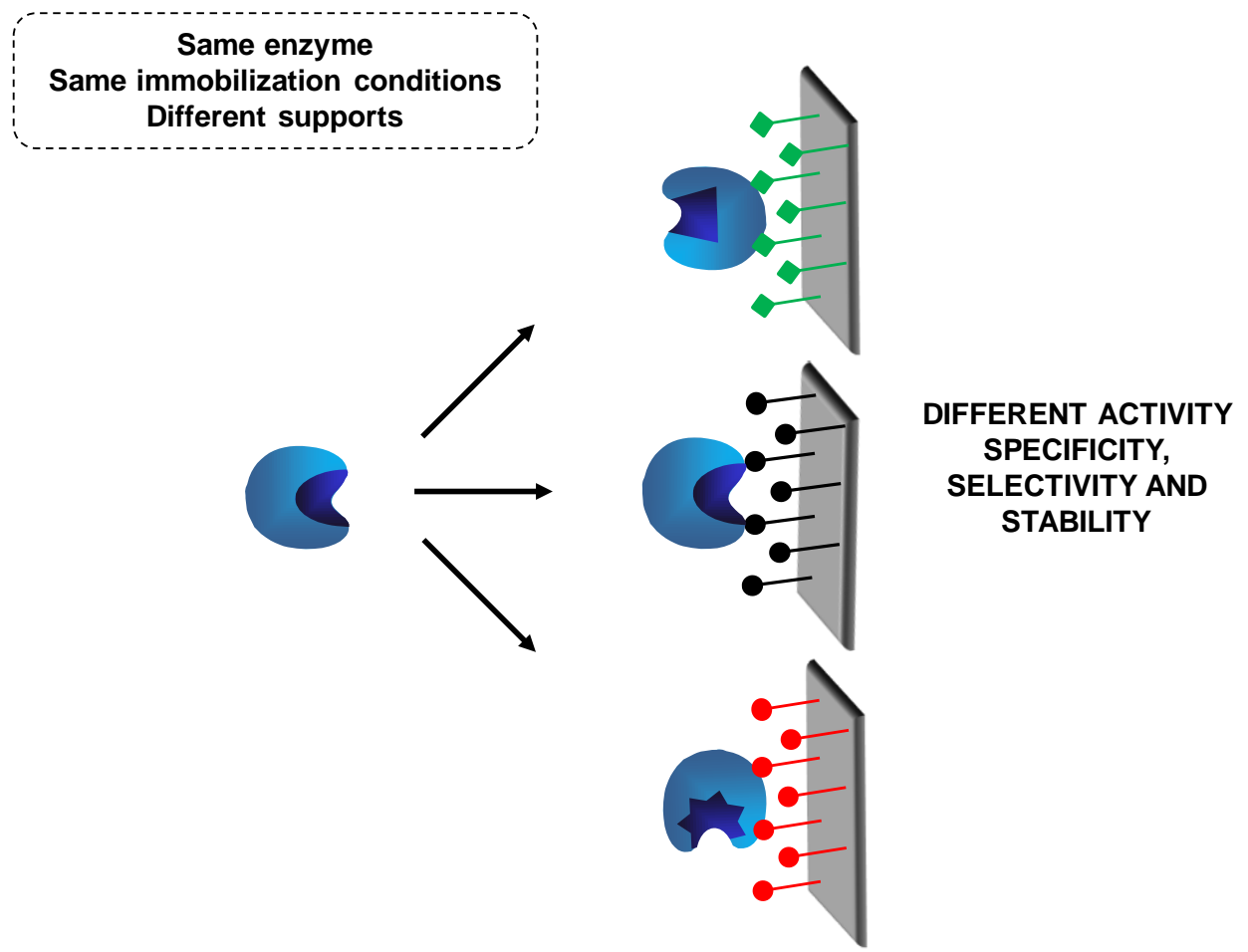

Figure 17. Effect of the immobilization support on the conformation of the immobilized enzyme. Tuning lipase activity, selectivity, specificity and stability. 


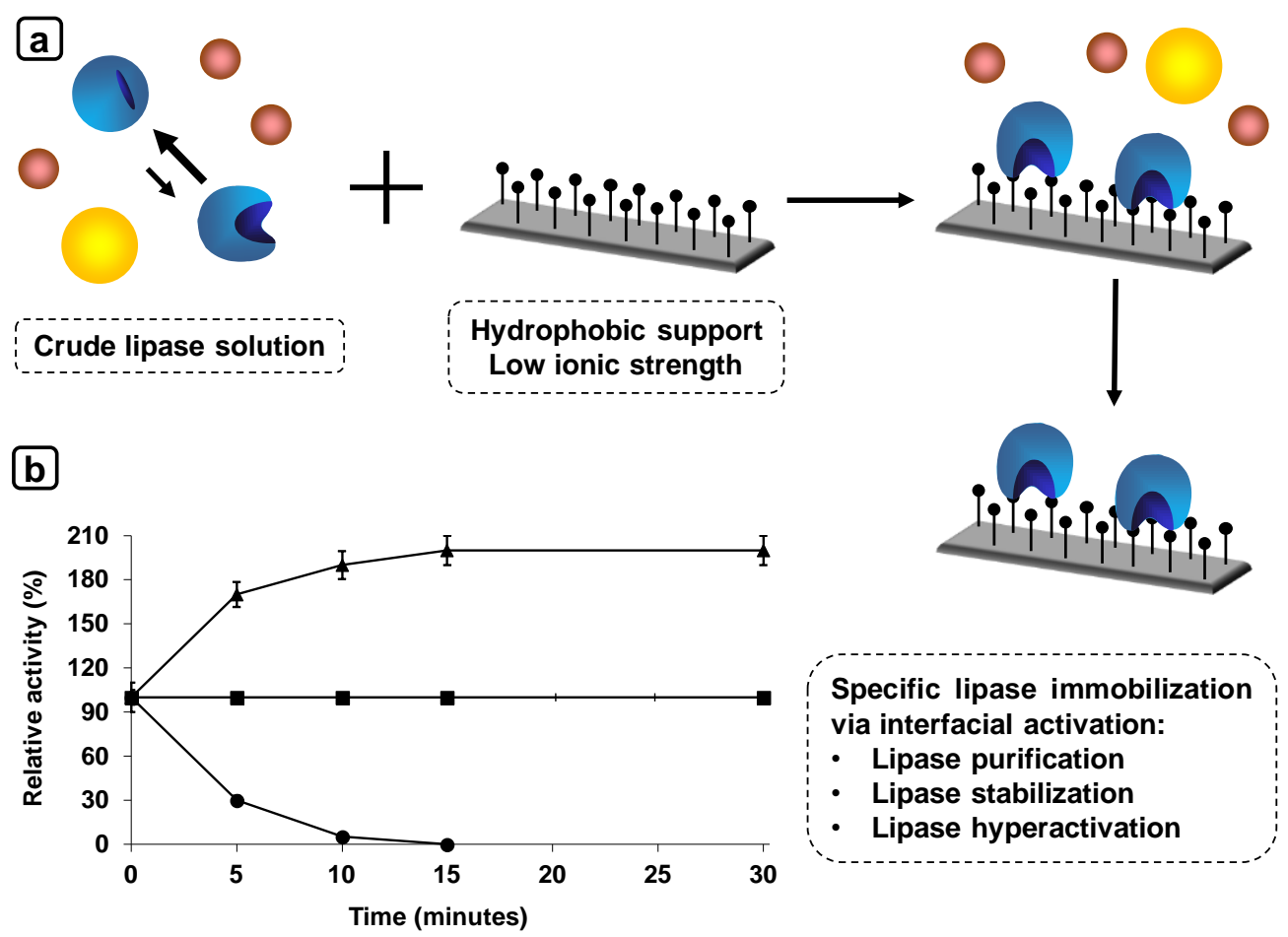

Figure 18. (a) Interfacial activation of lipases on hydrophobic supports at low ionic strength: stabilized, purified and hyperactivated enzyme form. (b) Standard immobilization course of lipases on hydrophobic supports. Solid triangles: Suspension. Solid Squares: Reference. Solid circles: Supernatant.

Using most enzymes, an intense multipoint covalent attachment is the best way to improve enzyme stability [62]. This process may not be simple, requiring a suitable active group in the support and a proper immobilization protocol (that in many instances may have several steps) [359]. In the case of lipases, all these advantages may be obtained by a very simple immobilization strategy. Using lipases, the best protocol to have an improved biocatalyst is just a simple physical adsorption of the enzyme on the support: the interfacial activation of the lipases versus support hydrophobic surfaces [360]. This protocol produces the one-step immobilization/purification/stabilization/hyperactivation of the lipases, as immobilization involves the stabilization of the open form of the lipases [81] (Figure 18). This stabilized open form of the lipase is very stable [361-363], even more so than the lipases immobilized via multipoint covalent immobilization [364,365]. The method has other additional advantages, such as its simplicity, high immobilization rate and high stability of the supports that can be stored for long times without any risks of alteration. Novozym 435, the most used commercial lipase biocatalyst, is prepared using this immobilization strategy [250].

Although lipase immobilization on hydrophobic supports may be achieved under a wide range of conditions, it has been recently shown that the immobilization medium conditions may greatly alter the properties of the immobilized lipases, at least when using some lipases [366-368]. This may be considered as an advantage, as it permits the modulation of the enzyme properties using a single immobilization support [61], or as a problem, as this means that changes in the immobilization medium composition may produce biocatalysts with different catalytic properties (activity, specificity, stability), and this may be in some instances hard to control (Figure 19).

Lipase immobilization via interfacial activation is reversible [81,325]. That way it permits the reuse of the support after enzyme inactivation, but it also raises the main problem of this lipase immobilization strategy: the lipase may be released during operation, under drastic conditions (high temperatures, organic cosolvent presence) or in the presence of detergent-like substrates or products [154,323]. This enzyme release may be avoided using heterofunctional supports [155,369-377] 
or by physical or chemical crosslinking of the immobilized enzymes [154,327,378-380] (Figure 20). That way, many examples of combilipases are based on mixtures of immobilized lipases.

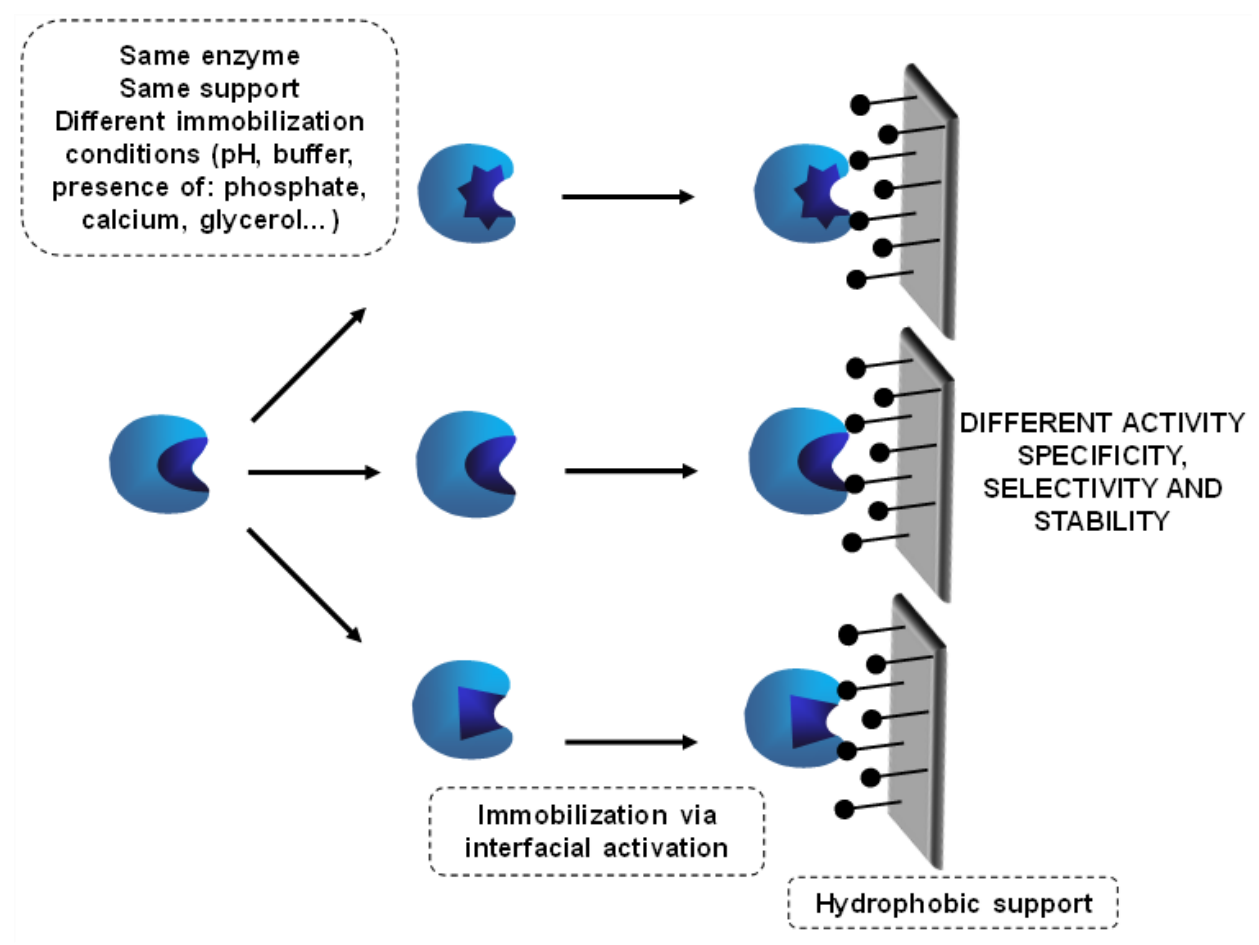

Figure 19. Effect of the immobilization conditions on hydrophobic supports on the conformation of the immobilized enzyme. Tuning enzyme activity, selectivity, specificity and stability.

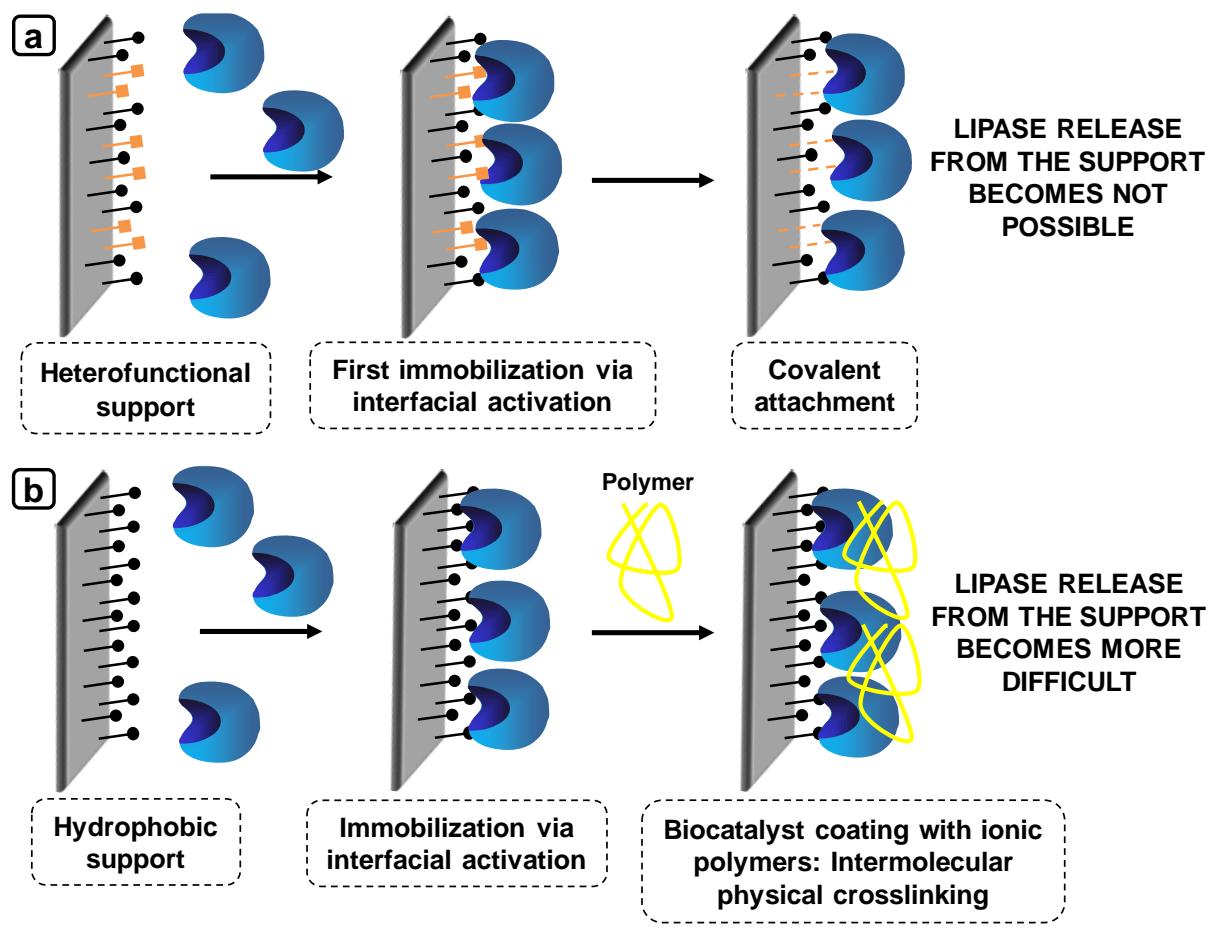

Figure 20. Preventing the risk of lipase release when immobilized on hydrophobic supports by (a) use of heterofunctional acyl-reactive groups supports or (b) physical intermolecular crosslinking with ionic polymers. 


\subsection{Use of Mixtures of Immobilized Lipases}

\subsubsection{Hydrolysis of Oils and Fats Using Individually Immobilized Combilipases}

Commercial immobilized lipases Lipozyme TL IM and Lipozyme RM IM were used in the hydrolysis of soybean oil, comparing the use of individual enzymes and combilipases [160]. Optimal results were obtained utilizing a mixture of 65\% Lipozyme TL IM and 35\% Lipozyme RM IM, with higher reaction rates and yields (95\%) than using the individual enzymes. Later on, this research group used the mixture of three commercial immobilized lipases, adding to the previous ones, the biocatalyst Novozym 435 [242]. Although Lipozyme TL IM was the most active biocatalyst and Novozym 435 was the least active one, the combination of 80\% of Lipozyme RM IM and 20\% of Novozym 435 gave better activity and yields of the use of just Lipozyme TL IM.

\subsubsection{Use of Individually Immobilized Combilipases in Biodiesel Production}

The use of immobilized lipases in biodiesel production is perhaps the first application of combilipases. S. W. Kim and co-workers were pioneers in this concept and very active group in this area. In a first paper, they showed that using immobilized lipases from R. oryzae or C. rugosa in the production of biodiesel using soybean oil, the yields were 70\% (after $18 \mathrm{~h}$ ) or 20\% (after $30 \mathrm{~h}$ ) [161]. Using of a mixture of both immobilized lipases, yields became $99 \%$ after $21 \mathrm{~h}$ of reaction. Later, they optimized the process, using a 75\% (mass) of the immobilized lipase from $R$. oryzae, reaching a biodiesel yield of $98 \%$ in only $4 \mathrm{~h}$ [381]. In a further research, they studied this process in batch or continuous way (stepwise addition of methanol was used in the batch process) [382]. The batch process gave $98.33 \%$ after $4 \mathrm{~h}$. The continuous process design required considering mass transfer problems. After optimization, a conversion yield of biodiesel of $97.98 \%$ after $3 \mathrm{~h}$ was achieved [382]. Later, they analyzed this use of these combilipases in supercritical carbon dioxide [383]. After optimization, the batch process gave a biodiesel conversion yield of $99.13 \%$ after $3 \mathrm{~h}$; that was improved to $99.99 \%$ after $2 \mathrm{~h}$ when $90 \mathrm{mmol}$ methanol was used in a stepwise reaction.

Later, other research groups also used this concept. For example, a combilipase composed of a mixture of Novozym 435 and Lipozyme TL IM, was utilized as catalyst in the production of biodiesel from methanol and stillingia oil [384]. The objective of this research was to analyze the effect of the presence of some solvents to improve the solubility of methanol and the produced glycerol. The authors used a relation of 1.96\% Novozym 435 and 2.04\% Lipozyme TL IM regarding the oil weight. Optimal results were obtained using a mixture of $60 \%$ acetonitrile and $40 \% \mathrm{t}$-butanol $(v / v)$ as a reaction medium. After optimization, a more than 95\% biodiesel yield was obtained [384]. Later, this research group utilized Novozym 435 and Lipozyme TL IM to produce biodiesel from methanol and lard, optimizing the reaction by response surface methodology [385]. The best results were obtained using a combilipases formed by 49/51 (Novozym 435/Lipozyme TL IM) total lipases (w/w). After $20 \mathrm{~h}$ of reaction, a biodiesel yield of 97.2\% was obtained [385]. Combilipases composed by Novozym 435 and Lipozyme TL IM were also utilized to produce biodiesel from methanol and waste cooking oil using tert-butanol as solvent [386]. After optimization, the biodiesel yield was up to $83.5 \%$. They later studied the possibility of using ionic liquids as reaction medium [387]. They selected 1-ethyl-3-methylimidazolium trifluoromethanesulfonate, and the combilipases produced a biodiesel yield of $99 \%$ in these conditions. The combilipase was more active in this ionic liquid medium than in solvent-free or using solvents such as tert-butanol or isooctane media [387].

In another paper, five immobilized lipases were employed to produce biodiesel using ethanol and palm oil in a solvent-free system [388]. The best results obtained using the individual enzymes were obtained using the Lipase AK from Ps. fluorescens, but they were improved using a combilipase of this immobilized enzyme and Lipase AY from C. rugosa. Using a continuous packed-bed reactor, yields over $67 \%$ of biodiesel were obtained [388]. In another paper, Lipozyme TL IM and Lipozyme RM IM were utilized in biodiesel production using ethanol and soybean oil [160]. Using the central composite design and the response surface methodology, the reaction was optimized. The best results 
were obtained using $80 \%$ of Lipozyme TL IM and 20\% Lipozyme RM IM, reaching a yield of $90 \%$ (more than doubling the results using only Lipozyme RM IM and 15\% higher than employing only Lipozyme TL IM) [160]. In another paper, different lipases were utilized as catalysts in the synthesis of biodiesel from the crude oil extracted from spent coffee grounds, and they found that the biocatalyst with better performance was Novozym 435 (conversion of $60 \%$ in $4 \mathrm{~h}$ ) [389]. After optimization (including oil purification), the conversion yields were improved to $88 \%$ in $24 \mathrm{~h}$. Mixing Novozym 435 with Lipozyme RM IM, yields were improved and reaction rates enhanced [389]. In another paper, olive and palm oils were utilized to produce biodiesel using ethanol as alcohol using Novozym 435, Lipozyme TL IM and Lipozyme RM IM [273]. Optimization showed that the best results were reached using combilipases, and that the optimal composition of the combilipases depended on the substrate. Using olive oil, the optimal combilipase was composed of $58.5 \%$ of Novozym $435,29.0 \%$ of Lipozyme TL IM and 12.5\% of Lipozyme RM IM. This permitted it to reach a 95\% biodiesel conversion in $18 \mathrm{~h}$ of reaction, while the best individually immobilized lipase (Novozym 435) gave only 50\%. The composition of the optimal combilipases was very different when the oil changed. That way, using palm oil, the optimal combilipase did not have Novozym 435 , but $52.5 \%$ of Lipozyme TL IM and $47.5 \%$ of Lipozyme RM IM. This gives an $80 \%$ biodiesel conversion in $18 \mathrm{~h}$, while the results obtained when using the best individual enzyme for this oil, Lipozyme TL IM, was a biodiesel yield of only 44\% [273]. One contribution used a combilipase composed of used and discarded immobilized lipases from C. rugosa, Ps. cepacia, R. oryzae and lipase from porcine pancreas type II, and Novozym 435 , as catalysts of the biodiesel productions from nonedible oils [337]. Stepwise addition of $6 \mathrm{mmol}$ of methanol to $1 \mathrm{mmol}$ of oil permitted to reach a $93 \%$ biodiesel yield, and adding silica gel the yields increased to $97 \%$ biodiesel. In a further research effort, lipase B from C. antarctica and lipase from R. miehei were covalently immobilized onto epoxy-functionalized silica and utilized to produce biodiesel from methanol and wasted cooking oil [390]. The combilipase formed by both immobilized lipases was used, and response surface methodology and a central composite rotatable design were utilized to optimize the process. The best combilipase was composed by a $75 \%$ of immobilized lipase B from C. antarctica and a $25 \%$ of the immobilized lipase from $R$. miehei; the best results were obtained using $10 \% \mathrm{t}$-butanol to oil (10 $\mathrm{wt} \%$ ) and silica gel (yields were $91.5 \%$ ).

The use of a plug-flow, packed-bed continuous reactor and tert-butanol as solvent was analyzed utilizing a combilipase composed of commercial immobilized lipases and two different oils [391]. The optimal combilipases varied depending on the oil. When employing wasted cooking oil, the combilipase was formed by Novozym 435 (35\%), Lipozyme TL IM (40\%) and Lipozyme RM IM (25\%). When using soybean oil, the combilipases was formed by Novozym $435(50 \%)$, Lipozyme TL IM $(22.5 \%)$ and Lipozyme RM IM $(27.5 \%)$. The presence of glass beads facilitated the flow of this viscous substrate solution in the mixture of different biocatalysts, prepared using different supports [391].

In another paper, homemade biocatalysts were prepared to produce biodiesel from ethanol and macauba pulp oil [392]. To reach this goal, lipases from Burkholderia cepacia and T. lanuginosus were covalently immobilized on desilicated and thiol-modified ZSM-5. The highest yields (just under 95\%) and reactions rates ( $48 \mathrm{~h}$ of reaction) were obtained by the use of the immobilized combilipases [392].

The use of ultrasound in the biodiesel production using combilipases has been studied. For this purpose, methanol and waste frying oil or soybean oil were used as substrates and Novozym 435, Lipozyme TL IM and Lipozyme RM IM were used as biocatalysts [393]. The best combilipase composition was designed by a statistical design of three factors. Ultrasound stirring and these optimized combilipases permitted it to get a biodiesel yield of about $90 \%$ when using soybean oil and $70 \%$ using the wasted oil after $18 \mathrm{~h}$ of reaction [393]. The same group used ultrasound stirring in the biodiesel production from methanol and soybean oil catalyzed by individual immobilized enzymes or the combilipase composed by the mixture of these immobilized enzymes, studying the effects of pulse conditions and ultrasonic amplitude [394]. The best results were obtained using an optimum combilipase formed by 10\% Lipozyme TL IM, 15\% Lipozyme RM IM and 75\% Novozym 435, time pulse of $15 \mathrm{~s}$, duty cycle of $50 \%$ and ultrasonic amplitude of 30\%. The presence of tert-butanol did not 
improve the yields under ultrasounds stirring, while it did under mechanical stirring, suggesting that ultrasonic technology was enough to eliminate the diffusional problems. Under optimal conditions, the proposed combilipase produced $75 \%$ ethyl esters while the best individual lipase gave only $55 \%$ in $5 \mathrm{~h} \mathrm{[394].}$

In another paper, oil from Isochrysis galbana was used to produce biodiesel utilizing commercial lipase from Ps. cepacia and commercial lipase B from C. antarctica [395]. The enzymes were immobilized on aminated SBA-15 mesoporous silica groups. Using wet extracted oil, the individual immobilized biocatalysts gave an $85.5 \%$ yield using the lipase B from C. antarctica and $87 \%$ using the immobilized lipase from Ps. cepacia (commercial Novozym 435 gave just under 70\%). The use of a combilipase composed of immobilized lipase B from C. antarctica and immobilized lipase from Ps. cepacia (in a relation 1:3) permitted to reach a yield of $97.2 \%$ [395].

Ethanolysis of soybean oil was intended using free lipases from T. lanuginosus and porcine pancreas, with very poor results using the individual enzymes [396]. Mixing equal activity proportions of both enzymes, the yields increased 5 or 100 folds, but yields were still quite low (around $20 \% \mathrm{wt}$ ). The lipases were immobilized using the cross-linked enzyme aggregate (CLEA) technique [70,397-399] (Figure 21) yielding biocatalysts with 119 (lipase from T. lanuginosus) and 89\% (lipase from porcine pancreas) of expressed activity. The combilipase formed by similar activities of both CLEAs permitted to reach a yield of 90.4 (wt.\%), while the individual CLEAs gave a yield of $84.7 \mathrm{wt} \%$ using porcine pancreas lipase CLEA or $75.6 \mathrm{wt} \%$ using T. lanuginosus CLEA [396].

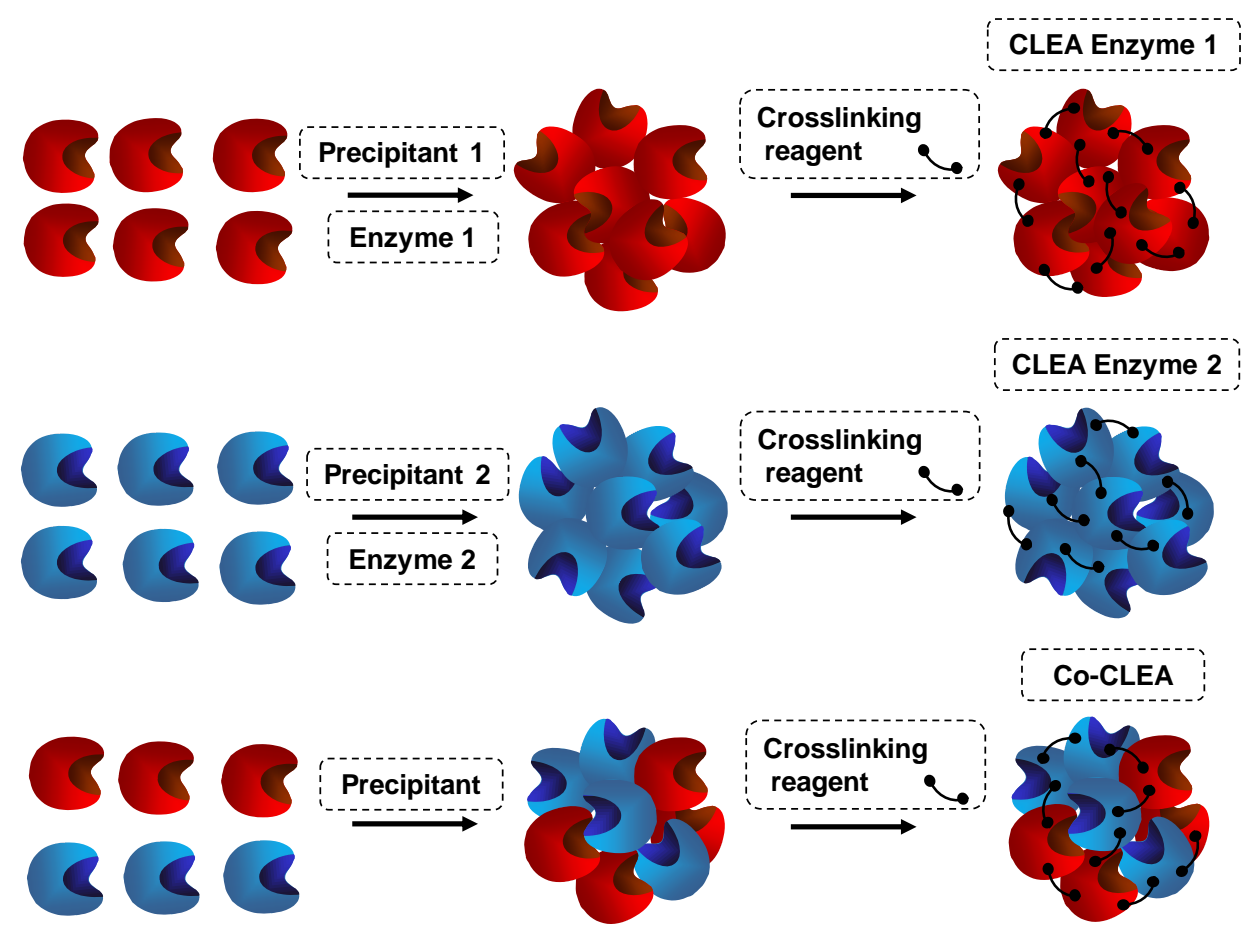

Figure 21. Individual immobilization or coimmobilization of enzymes using crosslinking enzyme aggregates technology (CLEA).

Display of enzymes on the surface of cells is an immobilization technique with growing popularity nowadays [400-403]. This technique for production of immobilized enzymes has been employed to separately express and display the lipase B from $C$. antarctica and the lipase from R. miehei on P. pastoris [404]. These biocatalysts were employed to produce biodiesel in tert-butanol and isooctane cosolvent media using statistical optimization. The use of a combilipase with the two displayed lipases (in different yeast cells) gave an ester yield higher than $90 \%$ in $12 \mathrm{~h}$, higher than the use of the individual biocatalysts [404]. 
The synergy between immobilized lipase from R. oryzae and Novozym 435 in biodiesel production was showed in another research, increasing the yield by $30 \%$ compared to the results obtained using the immobilized lipase from R. oryzae [405]. After optimization, a biodiesel yield of $98.3 \%$ in $21 \mathrm{~h}$ was achieved. The authors also showed that the combination of Novozym 435 with other lipases with a similar regioselectivity to the lipase from $R$. oryzae showed similar synergies [405]. Later, the same group used rapeseed oil deodorizer distillate as raw material to produce biodiesel. This is a complex mixture of glycerides and free fatty acids, rich in phytosterols [406,407]. This makes the situation even more complex, as now the lipase must be selected to efficiently catalyze both esterification and transesterification reaction, making the concept of combilipases even more interesting. That way, biodiesel was produced using this substrate and methanol, achieving the one-pot esterification of the free fatty acids and the transesterification of the glycerides in a solvent-free system [408]. As catalysts, Novozym 435 and immobilized lipase from Ps. cepacia G63 were employed. The use of combilipases composed by both immobilized enzymes gave better results than the individual enzymes, and it gave an ester yield over 95\% under optimal conditions. The process did not affect the phytosterols [408]. In a somehow similar situation, soybean oils with acid contents ranging from 8.5 to 90 and ethanol were used to produce biodiesel using Novozym 435, Lipozyme TL IM and Lipozyme RM IM [409]. Although Novozym 435 and Lipozyme RM IM were efficient in the decrease of oil acidity, a synergistic effect occurred when a combilipase using Novozym 435 and Lipozyme TL IM was used, doubling the ester production using an oil with an acidity value of 90 .

\subsubsection{Other Uses of Immobilized Combilipases}

As in the case of the free enzymes, interesterification is one of the reactions where immobilized combilipases have been utilized. For example, the enzymatic interesterification of coconut oil and palm stearin was performed using Novozym 435, Lipozyme TL IM and Lipozyme RM IM [410]. Some dual combilipases, such as mixtures of equivalent amounts of Novozym 435 and Lipozyme TL IM or Novozym 435 and Lipozyme RM IM, presented a significant synergistic effect as well as an enhanced degree of interesterification. The authors show that the carrier material may play an important role. Combilipases formed by immobilized lipases and non-immobilized lipase from Ps. flourescens enhanced the activity of the free enzyme. A combilipase formed by $70 \%$ free lipase AK mixed with $30 \%$ of any of the immobilized lipases more than doubled the theoretical activity. The coimmobilization of the free lipase on the support was proposed to explain this effect, and that was shown by a reaction catalyzed by free Lipase AK-and an immobilized but inactivated lipase preparation [410]. However, this experiment could be explained by some role of the support where the lipase is immobilized on the reaction (e.g., perhaps facilitating the acyl migration), not necessarily by the immobilization of the enzyme, that may be hard during the reaction in such a complex medium (Figure 15). In another paper, extra virgin olive oil, tripalmitin, arachidonic acid and docosahexaenoic acid were utilized to produce structured lipids with high palmitic acid content at the sn-2 position enriched with arachidonic acid and docosahexaenoic acid [411]. This means that interesterification and acidolysis occurred and the researchers, among other possibilities, used a combilipase formed by Novozym 435 and Lipozyme TL IM to analyze if some synergistic effect could be found. In parallel, Novozym 435 was used to catalyze the intereserification reaction in a first step and Lipozyme TL IM was utilized to catalyze the acidolysis in a second step (using a sequential design). All products presented more than $50 \mathrm{~mol}$ $\%$ palmitic acid at the sn-2 position, but the use of one-pot approach and the combilipase made the reactions faster [411].

Novozym 435 and Lipozyme RM IM were used in the enzymatic synthesis of kojic ester via esterification of kojic acid and oleic acid [412]. This is a reaction where just a single modification of each substrate is intended, phenol hydroxyl group of kojic acid is not very reactive. After optimization, the best results were found using equal amounts of both immobilized lipases (ester yields were $70 \%$ ). This is one of the few examples of the use of combibiocatalysts in the case of monofunctional 
substrates, and may be a consequence of some of the changes in the reaction conditions explained in the Section 1.2.1 [412,413].

In another example, isosorbide diester plasticizer was synthesized using immobilized lipase from Yarrowia lipolytica Lip 2, Lipozyme RM IM or Novozym 435 [414]. The most efficient enzymes, immobilized lipase from Y. lipolytica or Lipozyme RM IM, did not produce the $S$-isomer. To avoid this limitation, the researchers used a combilipase mixing one of those immobilized enzymes with Novozym 435 , greatly increasing the ester yields.

\subsection{Use of Mixtures of the Same Lipase Immobilized Following Different Protocols: A Special Combilipase}

Lipases, perhaps due to the flexibility of their active center and their mechanism of action, are among the enzymes whose properties may be more easily modulated via different strategies [415-420] as well as via immobilization [421-424] (Figure 17). It has been widely showed that changes in the immobilization protocol or the physical or chemical modification of the immobilized lipases may greatly alter the enzyme features [61]. Using the same immobilization mechanism, e.g., the interfacial activation of the lipase versus hydrophobic support surfaces [81,360], it has been shown that the change of the support features greatly affects the final enzyme specificity, activity and stability [425-427] — even immobilization of the same enzyme using the same hydrophobic support, but just changing the immobilization conditions gives very different enzyme properties [366-368] (Figure 19). In fact, it has been recently shown that the lipase from T. lanuginosus immobilized on a hydrophobic support under certain conditions was a strict 1,3 selective enzyme, being unable to hydrolyze 2-monoglycerides, while the enzyme immobilized under other conditions can hydrolyze 2-monoglycerides, and that also depended on the immobilization support [428,429].

In this context, Godoy and coworkers immobilized several lipases on Lewatit ${ }^{\circledR}$ VPOC1600 and Purolite ${ }^{\circledR}$ ECR1604 and used the biocatalysts to produce biodiesel from ethanol and palm olein [430]. Immobilizing the same lipase on these two supports, they found that the support affected the lipase performance. For example, using the lipase from T. lanuginosus, yields went from $78.2 \%$ (using Lewatit ${ }^{\circledR}$ VPOC1600) to $70.3 \%$ (using Purolite ${ }^{\circledR}$ ECR1604) [430]. This showed that the immobilization support affected the properties of the lipase as catalyst of biodiesel production, an already known fact $[165,431,432]$ (Figure 17). The mixture of the individually immobilized biocatalysts produced better results than the use of each independently immobilized enzyme catalysts. Moreover, very interestingly, the authors of this paper showed that using the mixture of both biocatalysts of the same enzyme, the yields were better than using the best biocatalysts, and increased to $86.1 \%$ [430]. That way, immobilization following different protocols should produce enzymes with different catalytic properties, and we can call these "combilipases". We have not found any other paper showing this fact.

\section{Use of Coimmobilized Lipases}

\subsection{Coimmobilization of Lipases: Advantages, Problems and Proposed Solutions}

Enzyme coimmobilization means the immobilization of different enzymes on the same particle (Figure 22). This coimmobilized enzymes are frequently used in cascade reactions, mainly because they provide a kinetic advantage, as the in situ production of the intermediate products allows expressing the activity of the intermediate enzymes from the beginning of the reaction, saving the lag time usually found in these cascade reactions [433-441] (Figures 22 and 23).

The full modification (hydrolysis or alcoholysis) of oils and fats may be considered a cascade reaction, as it involves three consecutive modifications of the triglyceride (Figures 4, 6 and 8-10). If the use of mixtures of lipases improves the reaction course, this means that some of the glycerides (substrate or intermediate products) are not good substrates for the lipase that performs the reaction best with the main substrate components (Figures 4 and 6). The fact that perhaps all the substrate modifications may be catalyzed by a single biocatalyst is not enough to discard the possibility of some advantage of lipase coimmobilization, as some the glycerides (initial substrate or intermediate 
products) may behave as inhibitors of the main enzyme, and its rapid elimination by other lipase will permit the expression of the maximum activity by the main enzyme.
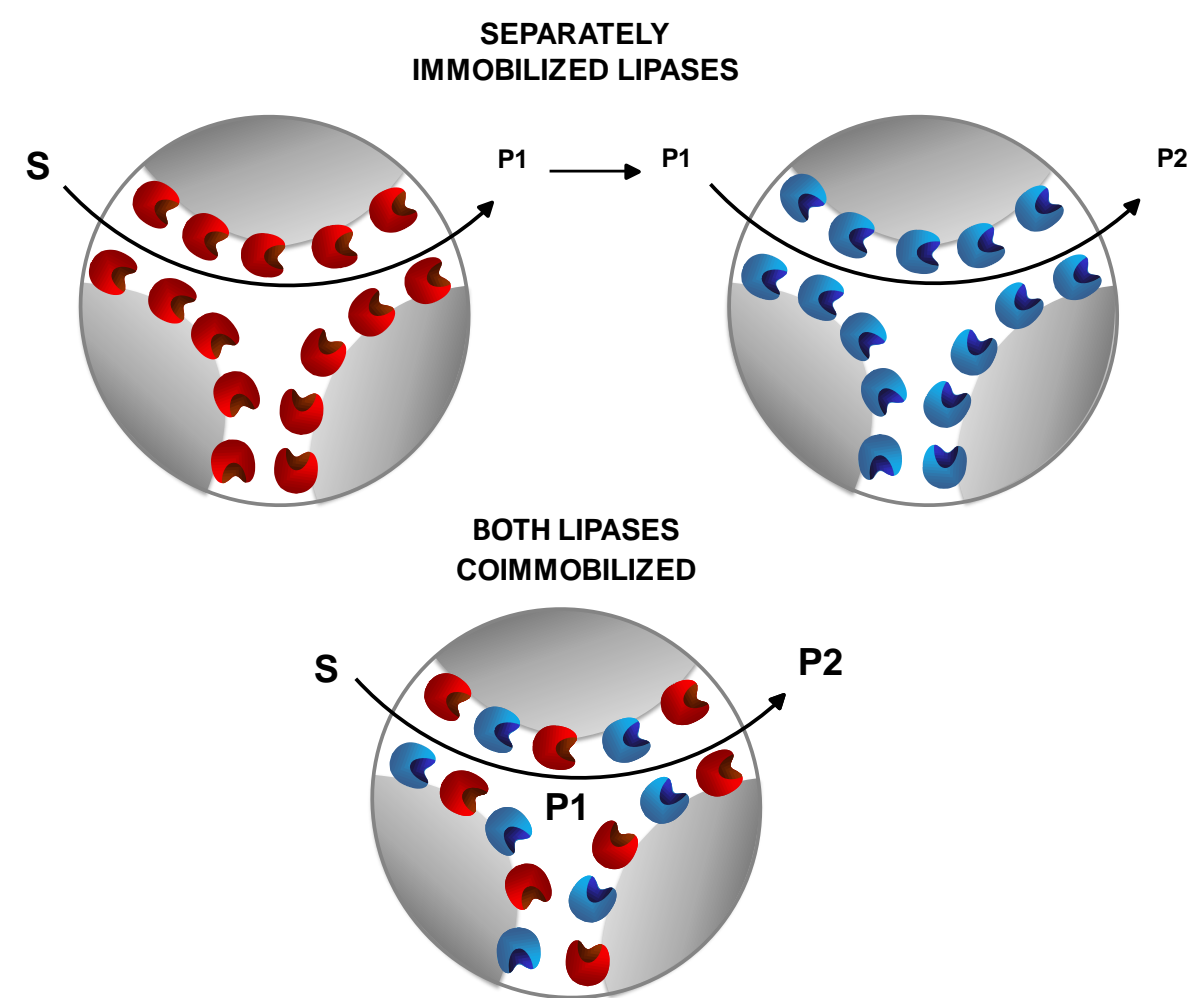

Figure 22. Schematic representation of the use of coimmobilized and independently immobilized enzymes in a cascade reaction.

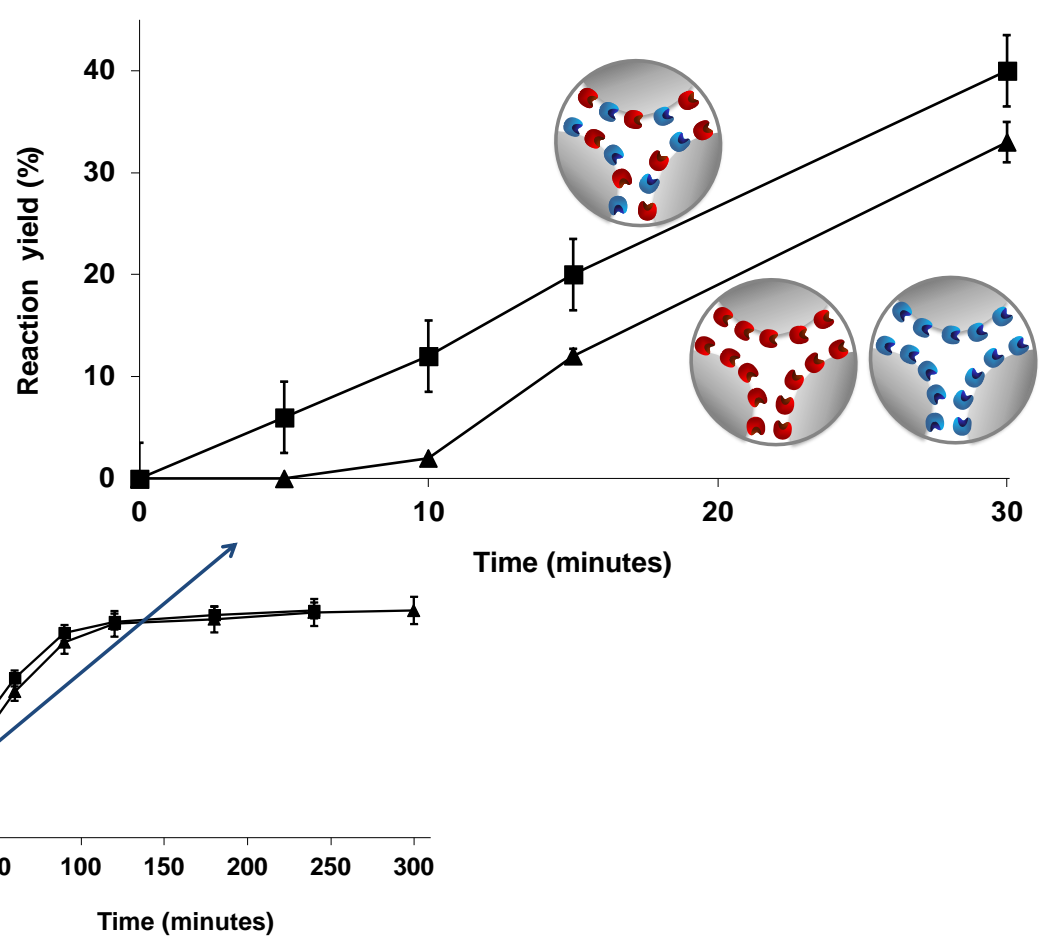

Figure 23. Effect of coimmobilization versus independently immobilized enzymes in a cascade reaction course. The effect is mainly relevant in the initial reactions rate because the lag time can disappear, but no so much in the whole reaction course. 
However, coimmobilization of enzymes, and of lipases, has some problems [60]. The first one is the necessity of immobilizing all enzymes following the same protocol. Fortunately, for lipases, interfacial activation using hydrophobic supports is an almost universal and very good immobilization protocol that may be applied to most lipases [81]. The second problem is the possibility that the different lipases may present very different stabilities. This makes discarding all immobilized enzymes necessary when just one has been inactivated [60,442] (Figure 24). Using reversible immobilization methods, such as interfacial activation, the support may be recovered, but only in a very lucky case the most stable enzyme will remain on the support when the inactivated one is released from it. However, at least this will permit the reuse of the support (Figure 25). That means that coimmobilization of several enzymes should consider not only the advantages, but also the problems of the coimmobilization [287].

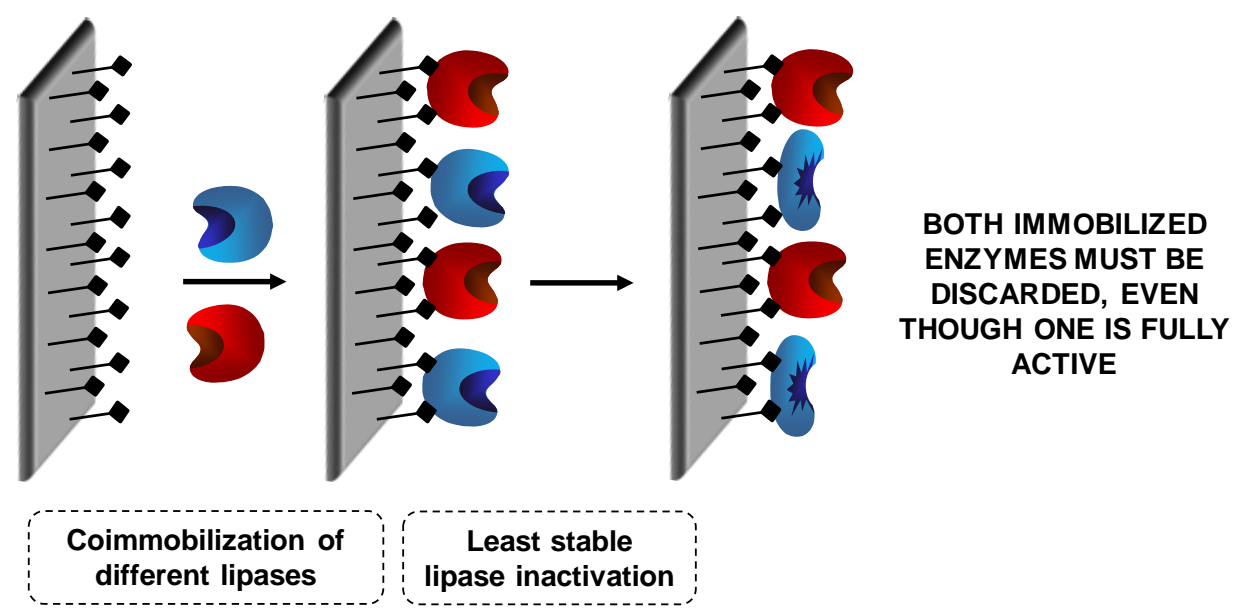

Figure 24. The problem of covalently coimmobilizing enzymes with different stabilities: both immobilized enzymes must be discarded when the least stable enzyme is inactivated.

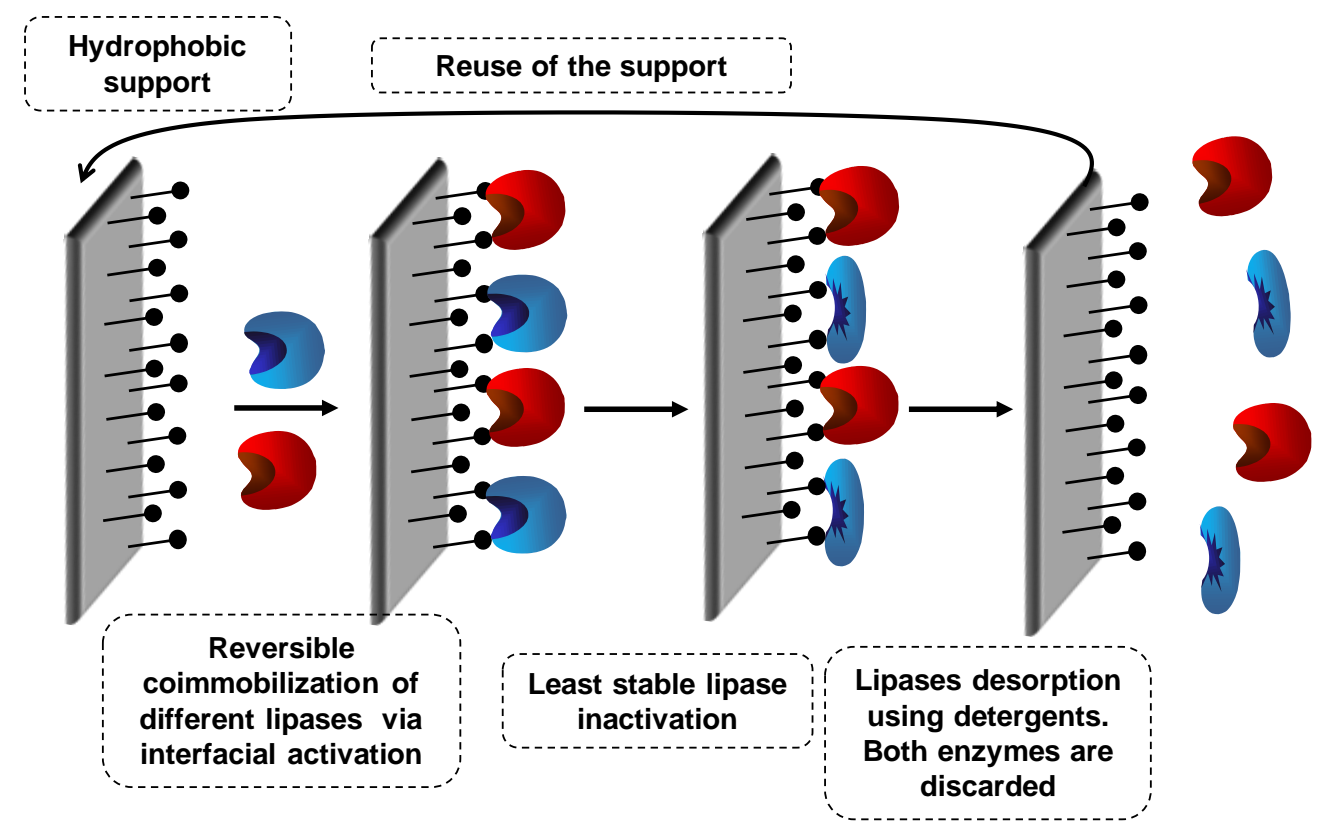

Figure 25. The problem of coimmobilizing two lipases with different stabilities via interfacial activation on hydrophobic supports: when the least stable enzyme is inactivated, both enzymes may be released from the support enabling the reuse of the support. 
Recently, some solutions have been designed to solve this latter problem, making the reuse of the most stable lipases after inactivation of the least stable ones possible. We will briefly present these strategies at the end of this section.

\subsection{Use of Coimmobilized Combilipases in Biodiesel Production}

We have found uses of coimmobilized combilipases only in biodiesel production. As in the case of the use of combilipases by mixing immobilized enzymes, S. W. Kim's group initialized and spearheaded the use of coimmobilized combilipases in the production of biodiesel. In a first paper, a continuation of a previous paper where the use of non-immobilized lipases from R. oryzae and C. rugosa for degumming by the action of phospholipase A2 had given good results in the production of biodiesel from crude canola oil, which had 100-300 ppm of phospholipids was presented using coimmobilized enzymes. To this goal, the enzymes were coimmobilized on silica gel [340]. After optimization, the ester yields reached a value of almost $90 \%$. Next, they performed a study comparing a combilipase of immobilized enzymes and coimmobilized combilipases in the transesterification of soybean oil and methanol at two different pressures [443]. At atmospheric pressure, the initial reaction rates of both combilipases decreased when the methanol concentrations increased. However, under supercritical fluid conditions, the initial reaction rate of both combilipases (individually immobilized or coimmobilized) increased until methanol concentration became double the concentration of oil. Results pointed out that the coimmobilized combilipase had higher initial reaction rate, but the negative effects of methanol on enzyme stability were also higher than using the mixture of immobilized lipases [443]. Later on, after optimizing the coimmobilization process, the coimmobilized combilipase was used in two different reactors [444]. A continuous packed-bed reactor and a batch system with stepwise methanol feeding were utilized. In the last system, around 99\% yield after $3 \mathrm{~h}$ of reaction was obtained and remained over $90 \%$ after 30 reuses. In a last paper from this group, the same lipases were coimmobilized on activated carbon modified with aminopropyltriethoxysilane and glutaraldehyde [445]. After optimization of the coimmobilization, the coimmobilized combilipase was used to produce biodiesel with very high yields using algal oil (93.8\%), waste cooking oil (95.7\%) and soybean oil (98.5\%) after only $4 \mathrm{~h}$ of reaction.

Other research groups also used coimmobilized combilipases in the production of biodiesel. For example, lipase B from C. antarctica and lipase from $R$. miehei were coimmobilized on epoxy-functionalized silica gel using different enzyme ratios [446]. The transesterification of palm oil with methanol to produce fatty acid methyl esters catalyzed by these biocatalysts was optimized by response surface methodology and a central composite rotatable design. The best ratio between both enzymes was 2.5:1 (lipase B from C. antarctica: lipase from R. miehei), giving an ester yield of 78.5\% [446]. In a continuation of the work discussed in Section 6.2, lipases from T. lanuginosus and R. miehei were coimmobilized via interfacial activation on Lewatit ${ }^{\circledR}$ VPOC1600 and Purolite ${ }^{\circledR}$ ECR1604 [430]. The biocatalysts were used in ethyl ester production using palm olein as substrate. The authors described that coimmobilization improved the results of the use of mixtures of independently immobilized lipase (see Section 6.2). The support also has a great effect; the results obtained using Lewatit ${ }^{\circledR}$ VPOC1600 were better than those using Purolite ${ }^{\circledR}$ ECR1604. The best results were obtained with coimmobilized lipases on Lewatit ${ }^{\circledR}$ VPOC 1600 , biodiesel yield increased from $81.8 \%$ to $89.5 \%$ compared to the respective mixture of individually immobilized enzymes [430].

Protein-coated microcrystals are not a much-utilized immobilization strategy [389]. This immobilization technique consists in the use of water-soluble, micron-sized crystalline particles coated with the target enzyme. The biocatalysts are prepared in a one-step rapid dehydration process [447-449]. This strategy was used to prepare a coimmobilized combilipase coated microcrystals including lipase B from C. antarctica and lipase from R. miehei, using $\mathrm{K}_{2} \mathrm{SO}_{4}$ as the core of the particles, giving similar results to the best results obtained using the commercial immobilized enzymes $(83 \%$ conversion in $48 \mathrm{~h}$ ) [389].

Finally, the display of enzymes on the surface of surface of cells [400-403] has been employed to co-express and co-display lipase B from C. antarctica and lipase from T. lanuginosus on the surface of 
P. pastoris cell as biocatalyst for biodiesel production [450]. This permitted a 95.4\% ester yield and a good operational stability.

\subsection{Preparation of Coimmobilized Combilipases to Reuse the Most Stable Enzymes}

As it has been explained in Section 7.1, enzyme coimmobilization has some drawbacks (Figures 24 and 25). These problems have not been considered in any of the above uses of combilipases. If they are not considered in the preparation of a biocatalyst, coimmobilization may afford more problems than advantages $[60,287]$. One of the points is that coimmobilization is only reasonable when that has some clear advantage over individual enzyme immobilization, e.g., in cascade reactions [60,287] (Figures 22-25). However, in some instances, the problems are ignored and several enzymes are coimmobilized, even stating that the intention is not to produce a biocatalyst to catalyze cascade reactions in one pot, but to produce the so-called "multipurpose biocatalysts" [32,451].

This is the case of the preparation of a combiCLEA containing lipase, $\alpha$-amylase, and phospholipase A2 [452]. The CLEA immobilization strategy is simple, but even using this strategy the optimal precipitant, crosslinking agent nature and concentration, feeding protein, etc., may be different for each specific enzyme [397-399] (Figure 21). Furthermore, it still has the problems of the coimmobilization and none of the gains, the recommendation should be to immobilize each enzyme in an individual way under optimal conditions $[60,287]$.

This reuse of the most stable enzyme is usually ignored in most papers, where only in many few instances the stability of the different coimmobilized enzymes is even presented. However, the problem was clearly exemplified when lipase B from C. antarctica immobilized on octyl agarose was coated with polyethylenimine (PEI) and the lactase from $A$. niger was coimmobilized on it via ion exchange [442] (Figure 26). The lipase was much more stable than the lactase, in a way that remained fully active when the lactase was almost fully inactivated. However, thanks to the different immobilization strategies employed for each enzyme, the inactivated lactase could be released to the medium after its inactivation without affecting the activity of the immobilized lipases. Just by incubation at high ionic strength to release the inactivated lactase, the immobilized lipase could be reused for many cycles involving lactase inactivation/lactase desorption/PEI recoating of immobilized lipase/new batch of lactase immobilization [442] (Figure 26). The reuse of a support may not compensate the costs of the recycling process, but in this case, by just an incubation at high ionic strength, the immobilized lipase could be reused for many cycles, and this may have a higher economical interest. The lipase coating with PEI produced an increase in lipase activity and stability [378,380], and even the treatment with glutaraldehyde to prevent the PEI release during lactase desorption produced some positive effects [379], making this coimmobilization strategy very suitable [453].

When the researchers analyzed the stabilities of some of the most used lipases, they found a great variety in lipase stabilities, and in fact, some lipases immobilized on octyl agarose via interfacial activation [360] remained fully active under conditions where other lipases were fully inactivated [454,455]. Thus, the utilization of different strategies to prepare a coimmobilized combilipase biocatalyst to reuse the most stable lipases has sense. First of all, it was shown that the use of PEI as coupling agent permitted to prepare multilayers of the same lipase $[456,457]$ or of different lipases [458] (Figures 27 and 28). A problem found when using some lipases was that the enzymes already immobilized on enzyme-PEI composites the enzyme was released when treating with PEI to immobilize a new lipase layer, requiring to treat the biocatalyst with glutaraldehyde to prevent enzyme release via covalent enzyme-polymer crosslinking [457]. Apparently, this may not look a coimmobilized combilipase when using the same lipase. However, the strategy presented finally three different immobilized lipase forms. The lipase in the bottom layer was the lipase immobilized via interfacial activation on octyl agarose, modified with PEI and glutaraldehyde, the second lipase layer (and all intermediate lipase layers) was the lipase immobilized via ion exchange, modified with glutaraldehyde and PEI, while the last layer, if desired, could be immobilized via ion exchange but without any other further modification $[457,458]$ (Figure 27). As explained above, the use of mixtures 
of the same lipase immobilized following different protocols permitted to have better results than the use of single immobilized catalysts [430], and we can call this "combilipase", as we have different lipase forms [61].

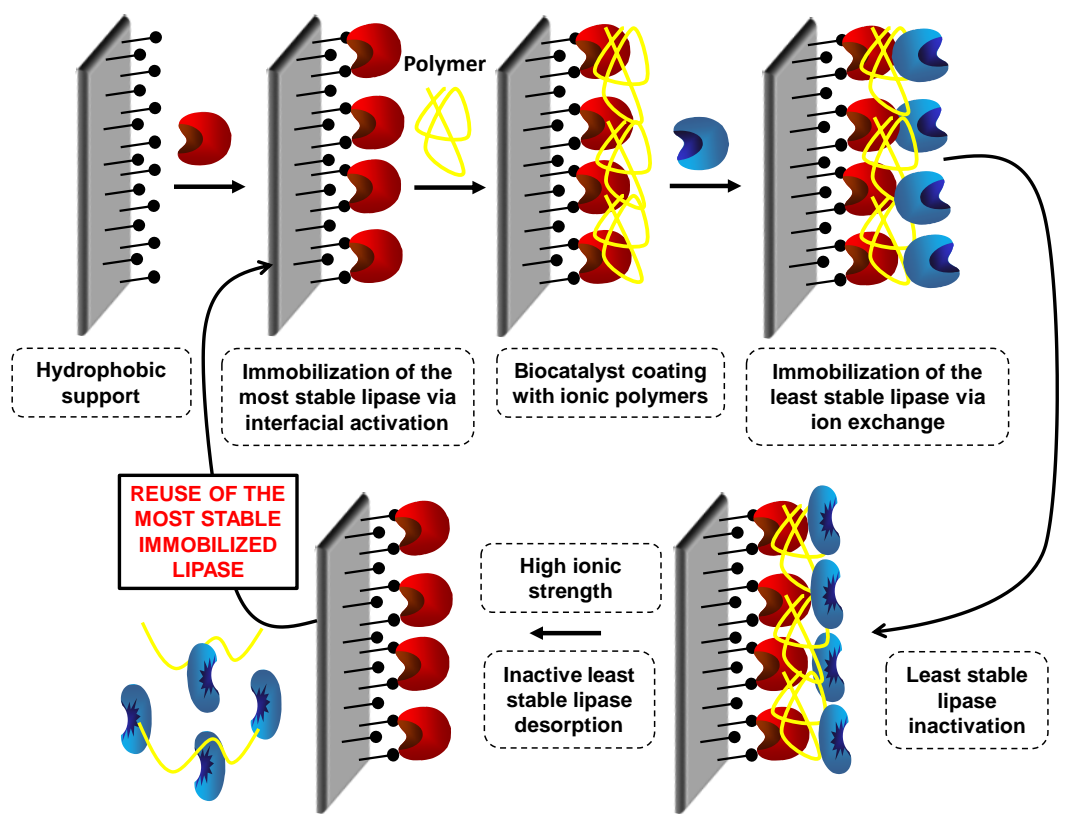

Figure 26. A strategy to coimmobilize two enzymes that permit the reuse of the most stable one combining immobilization via interfacial activation of the most stable enzyme, immobilized enzyme coating with ionic polymers and ion exchange immobilization of the least stable enzyme.

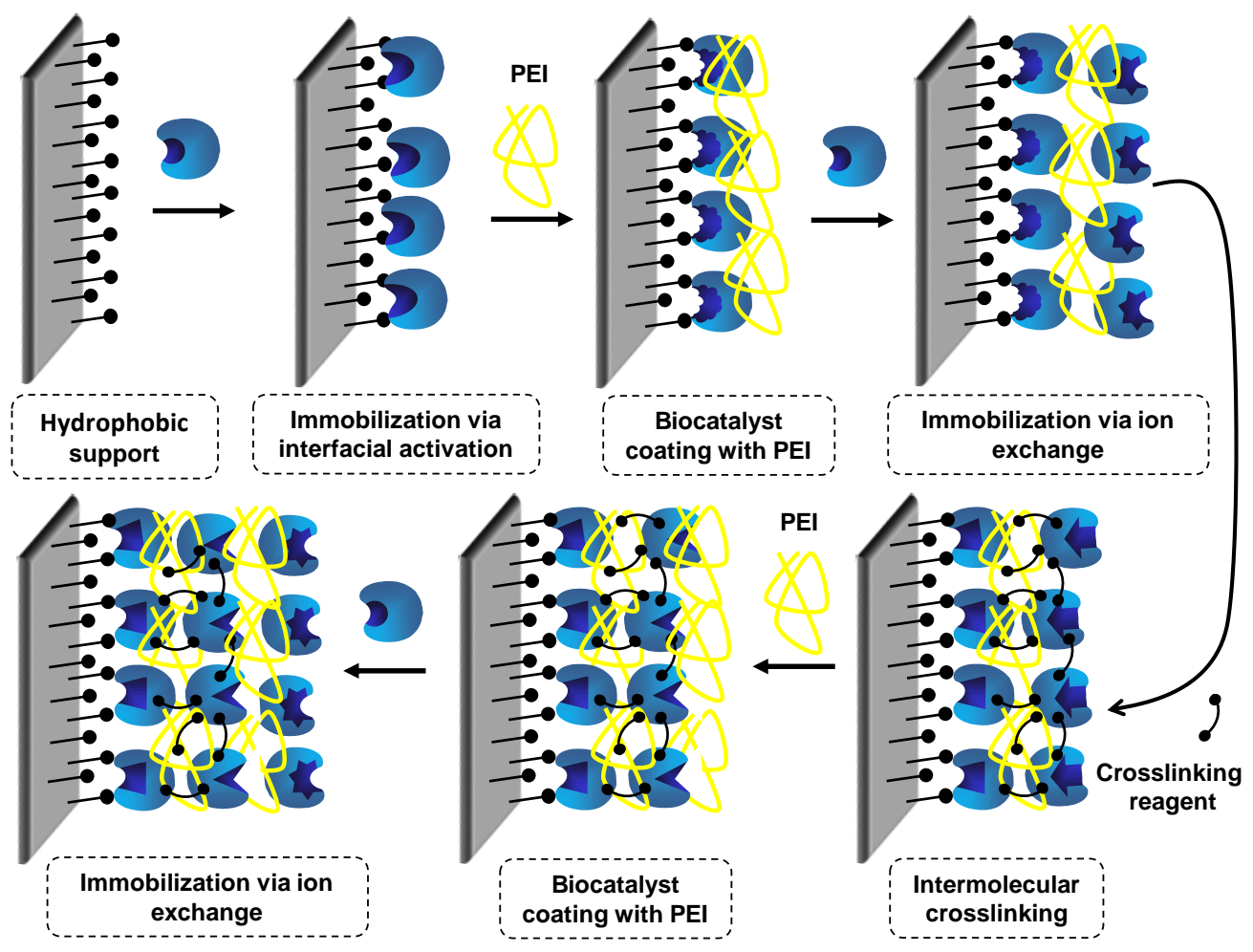

Figure 27. Preparations of a multilayer biocatalyst with the same enzyme employing PEI and glutaraldehyde as glue. The result is a combilipase bearing three lipase forms. 


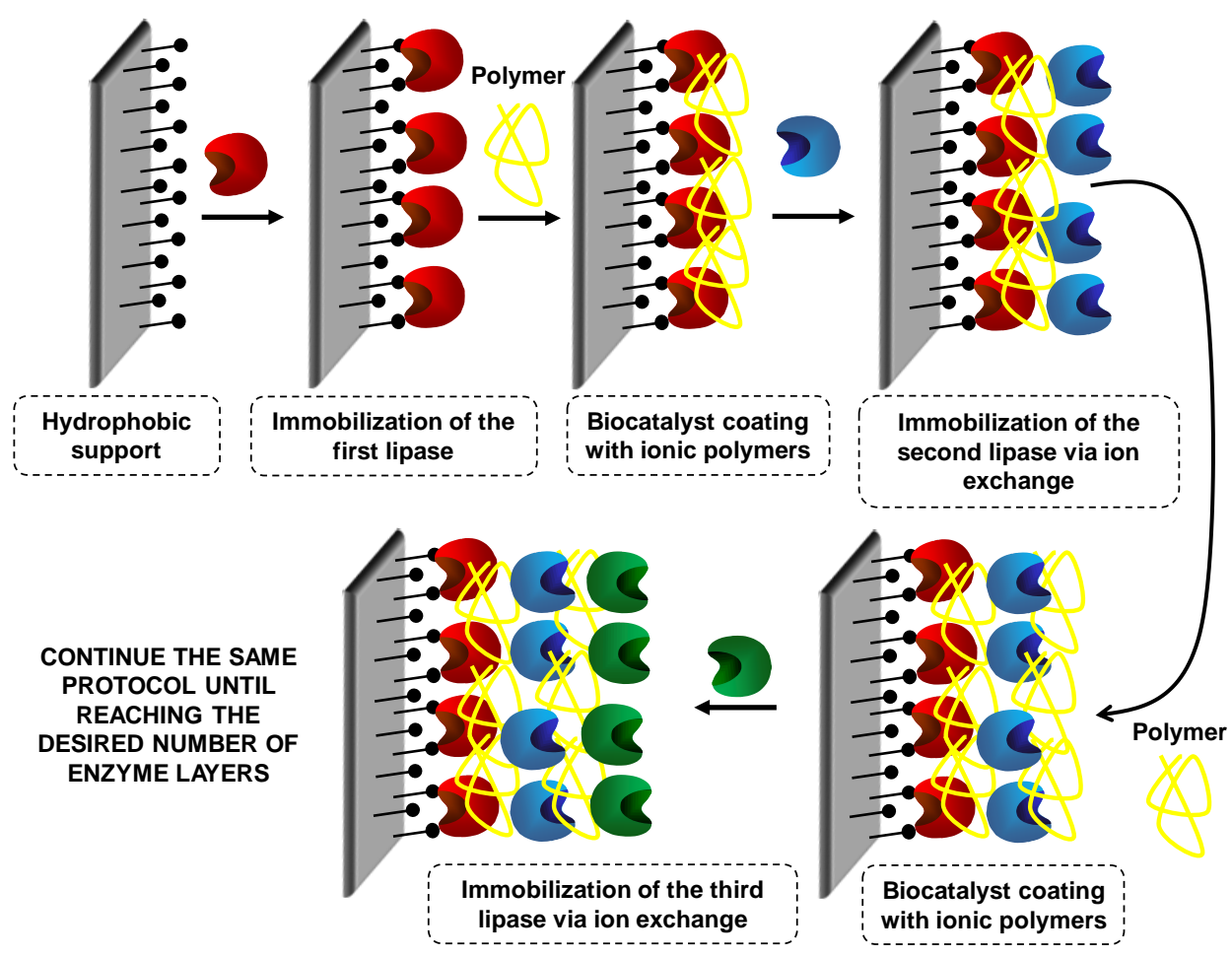

Figure 28. Coimmobilization of several enzymes with controlled spatial distribution using a multilayer strategy.

This enzyme layer by enzyme layer strategy, when immobilizing different enzymes, permitted to control the spatial distribution of the different enzymes, until five different lipases were immobilized using different spatial distribution, with very different impact on the final biocatalysts activity versus different substrates [458] (Figure 28).

Following the same strategy utilized to coimmobilize lipases and lactase [442] (Figure 26), several very stable lipases (lipases A and B from C. antarctica and lipase from T. lanuginosus) were immobilized on octyl-divinylsulfone agarose, treated with PEI and coimmobilized with several less stable enzymes (lipase from R. miehei and Lecitase Ultra) via ion exchange [459]. The most stable lipases could be reused for several cycles of stress inactivation of the least stable lipases/release of these inactivated enzymes/recoating of the immobilized stable enzymes with PEI/immobilization of a new batch of the non-stable lipases [459] (Figure 26).

Another strategy that permitted the reuse of the most stable lipase [454], this time using the advantages of the lipase immobilization via interfacial activation for all lipases [81], is based in the use of heterofunctional supports [359], using supports with hydrophobic acyl chains to get the interfacial activation of the lipase [360] and reactive groups able to give the covalent lipase immobilization [369]. The event that permits the first immobilization of the lipase on these supports is the lipase interfacial activation, and later, the formation of some enzyme-support covalent bonds may occur [369] (Figure 20). The most stable lipase is immobilized on the heterofunctional support, after getting some enzyme-support covalent bonds, the other groups in the support are destroyed, and the least stable enzymes may be immobilized just via interfacial activation $[454,455]$. This permitted the release of the least stable lipases after its inactivation by incubation in the presence of detergents [81], and enabled the reuse of the most stable lipases, that are covalently immobilized. Several lipases with similar stabilities may be immobilized using the same immobilization strategy. The main problem of this strategy is the release of all detergent molecules from the immobilized lipase biocatalysts [454].

However, these biocatalysts have not been assayed in the production of biodiesel or free fatty acids, all the utilized coimmobilized combibiocatalysts have not considered these problems of the enzyme stability of the different biocatalysts. 


\section{Conclusions}

This review shows how combilipases may have a great potential in the development of modifications of heterogeneous substrates. In fact, it looks an obvious solution to optimize this kind of processes. The improvements in free fatty acids or biodiesel production have been clearly illustrated because it is unlikely that a single lipase can modify all the different triglycerides in an oil, and less considering the partial glycerides produced during the reaction. Although we have been only able to find one case, the use of this combilipase concept may also have extension to monofunctional substrates, as the reactions conditions will change always during the reaction and this can be beneficial for some enzymes and negative for some others.

As expected, the use of immobilized enzymes offers some advantages compared to the use of the free enzymes, as recycling is simpler, the enzymes become more stable, and diverse reactor configurations may be utilized. Nevertheless, immobilization must be carefully designed, if we can really improve most enzyme features and not just facilitate enzyme recycling, immobilization advantages may benefit from their costs or derived problems. Moreover, although this has been only shown in one example, the preparation of combilipases using just one lipase but immobilized using different protocols may become an easy way to take the advantages of this idea. Our expectations are that this idea may be disseminated rapidly and many examples will be available in the future.

Another different point is the use of coimmobilized lipases. Considering just the problems derived from coimmobilization, it is necessary to consider if the gains are higher than the losses. Fortunately, lipases have been the model enzymes to design some strategies that solve the problem of enzymes bearing different stabilities. There are already strategies that permit to reuse the most stable enzymes after inactivation of the least stable enzymes. In fact, it has been showed that a combilipase may be built by immobilizing different layers of the same enzyme submitted to different modifications.

The authors of this review foresee that the use of combilipases, and combienzymes in general, will be more generalized in the near future, as the number of problems that this can solve in a reaction are many, although the use of several enzymes may complicate the design of the processes. Very likely, even some relatively simple processes will benefit from the use of mixtures of enzymes, having different responses to changes in the conditions of the medium, inhibition, specificity or selectivity. This is a reality in the case of oil and fats modification and combilipases, but we are convinced that the concept of optimal enzyme for a given process may be changed in the near future for the concept of optimal combienzyme. The formulation of these combienzymes may be in free, immobilized or coimmobilized enzymes forms, but also in combinations of different formulations.

Author Contributions: All authors search for the literature, participate in the writing of the first manuscript version and its editing. R.F.-L. and R.C.R. designed the structure and designed the concept. All authors have read and agreed to the published version of the manuscript.

Funding: This research was funded by Ministerio de Ciencia e Innovación-Spanish Government (project number CTQ2017-86170-R) and Generalitat Valenciana (PROMETEO/2018/076).

Acknowledgments: D.C. thanks to Ministerio de Ciencia e Innovacion-Spanish Government by a FPI. R. Martinez (Novozymes, Spain) is gratefully recognized by the continuous support to our research.

Conflicts of Interest: The authors declare no conflict of interest.

\section{References}

1. Chapman, J.; Ismail, A.; Dinu, C. Industrial applications of enzymes: Recent advances, techniques, and outlooks. Catalysts 2018, 8, 238. [CrossRef]

2. De Gonzalo, G.; Domínguez de María, P. Biocatalysis: An industrial perspective. In Catalysis Series; de Gonzalo, G., Domínguez de María, P., Eds.; Royal Society of Chemistry: Cambridge, UK, 2017; pp. 1-511, ISBN 978-1-78262-619-0.

3. Hughes, D.L. Biocatalysis in drug development-highlights of the recent patent literature. Org. Process Res. Dev. 2018, 22, 1063-1080. [CrossRef] 
4. Li, G.; Wang, J.; Reetz, M.T. Biocatalysts for the pharmaceutical industry created by structure-guided directed evolution of stereoselective enzymes. Bioorg. Med. Chem. 2018, 26, 1241-1251. [CrossRef] [PubMed]

5. Raveendran, S.; Parameswaran, B.; Ummalyma, S.B.; Abraham, A.; Mathew, A.K.; Madhavan, A.; Rebello, S.; Pandey, A. Applications of microbial enzymes in food industry. Food Technol. Biotechnol. 2018, 56, 16-30. [CrossRef] [PubMed]

6. Rosenthal, K.; Lütz, S. Recent developments and challenges of biocatalytic processes in the pharmaceutical industry. Curr. Opin. Green Sustain. Chem. 2018, 11, 58-64. [CrossRef]

7. Abdelraheem, E.M.M.; Busch, H.; Hanefeld, U.; Tonin, F. Biocatalysis explained: From pharmaceutical to bulk chemical production. React. Chem. Eng. 2019, 4, 1878-1894. [CrossRef]

8. Adams, J.P.; Brown, M.J.B.; Diaz-Rodriguez, A.; Lloyd, R.C.; Roiban, G.-D. Biocatalysis: A pharma perspective. Adv. Synth. Catal. 2019, 361, 2421-2432. [CrossRef]

9. Basso, A.; Serban, S. Industrial applications of immobilized enzymes-A review. Mol. Catal. 2019, 479, 110607. [CrossRef]

10. Bilal, M.; Iqbal, H.M.N. Sustainable bioconversion of food waste into high-value products by immobilized enzymes to meet bio-economy challenges and opportunities-A review. Food Res. Int. 2019, 123, 226-240. [CrossRef]

11. Bilal, M.; Iqbal, H.M.N. State-of-the-art strategies and applied perspectives of enzyme biocatalysis in food sector-Current status and future trends. Crit. Rev. Food Sci. Nutr. 2019, 1-15. [CrossRef]

12. Faber, K.; Fessner, W.-D.; Turner, N.J. Biocatalysis: Ready to master increasing complexity. Adv. Synth. Catal. 2019, 361, 2373-2376. [CrossRef]

13. Domínguez de María, P.; de Gonzalo, G.; Alcántara, A.R. Biocatalysis as useful tool in asymmetric synthesis: An assessment of recently granted patents (2014-2019). Catalysts 2019, 9, 802. [CrossRef]

14. Sheldon, R.A.; Brady, D.; Bode, M.L. The Hitchhiker's guide to biocatalysis: Recent advances in the use of enzymes in organic synthesis. Chem. Sci. 2020, 11, 2587-2605. [CrossRef] [PubMed]

15. Foley, A.M.; Maguire, A.R. The impact of recent developments in technologies which enable the increased use of biocatalysts. Eur. J. Org. Chem. 2019, 2019, 3713-3734. [CrossRef]

16. Guajardo, N.; Domínguez de María, P. Continuous biocatalysis in environmentally-friendly media: A triple synergy for future sustainable processes. ChemCatChem 2019, 11, 3128-3137. [CrossRef]

17. Prier, C.K.; Kosjek, B. Recent preparative applications of redox enzymes. Curr. Opin. Chem. Biol. 2019, 49, 105-112. [CrossRef]

18. Sheldon, R.A.; Brady, D. Broadening the scope of biocatalysis in sustainable organic synthesis. ChemSusChem 2019, 12, 2859-2881. [CrossRef]

19. Woodley, J.M. Accelerating the implementation of biocatalysis in industry. Appl. Microbiol. Biotechnol. 2019, 103, 4733-4739. [CrossRef]

20. Hoyos, P.; Pace, V.; Hernaiz, M.; Alcántara, A.R. Biocatalysis in the pharmaceutical industry. A greener future. Curr. Green Chem. 2014, 1, 155-181. [CrossRef]

21. Alcántara, A.R. Biotransformations in Drug synthesis: A Green and powerful tool for medicinal chemistry. J. Med. Chem. Drug Des. 2018, 1, 1-7.

22. Alcántara, A.R. Biocatalysis and pharmaceuticals: A smart tool for sustainable development. Catalysts 2019, 9, 792. [CrossRef]

23. Sheldon, R.A.; Woodley, J.M. Role of biocatalysis in sustainable chemistry. Chem. Rev. 2018, 118, 801-838. [CrossRef] [PubMed]

24. Sheldon, R.A. Biocatalysis and green chemistry. In Green Biocatalysis; John Wiley \& Sons, Inc.: Hoboken, NJ, USA, 2016; pp. 1-15, ISBN 9781118828083.

25. Woodley, J.M. New frontiers in biocatalysis for sustainable synthesis. Curr. Opin. Green Sustain. Chem. 2020, 21, 22-26. [CrossRef]

26. Schoemaker, H.E. Dispelling the myths - Biocatalysis in industrial synthesis. Science 2003, 299, $1694-1697$. [CrossRef] [PubMed]

27. Ferrer, M.; Beloqui, A.; Timmis, K.; Golyshin, P. Metagenomics for mining new genetic resources of microbial communities. J. Mol. Microbiol. Biotechnol. 2009, 16, 109-123. [CrossRef] [PubMed]

28. Fernández-Arrojo, L.; Guazzaroni, M.-E.; López-Cortés, N.; Beloqui, A.; Ferrer, M. Metagenomic era for biocatalyst identification. Curr. Opin. Biotechnol. 2010, 21, 725-733. [CrossRef] 
29. Ferrer, M.; Martínez-Martínez, M.; Bargiela, R.; Streit, W.R.; Golyshina, O.V.; Golyshin, P.N. Estimating the success of enzyme bioprospecting through metagenomics: Current status and future trends. Microb. Biotechnol. 2016, 9, 22-34. [CrossRef]

30. Vieites, J.M.; Guazzaroni, M.-E.; Beloqui, A.; Golyshin, P.N.; Ferrer, M. Metagenomics approaches in systems microbiology. FEMS Microbiol. Rev. 2009, 33, 236-255. [CrossRef]

31. Guazzaroni, M.E.; Beloqui, A.; Golyshin, P.N.; Ferrer, M. Metagenomics as a new technological tool to gain scientific knowledge. World J. Microbiol. Biotechnol. 2009, 25, 945-954. [CrossRef]

32. Bilal, M.; Iqbal, H.M.N. Tailoring multipurpose biocatalysts via protein engineering approaches: A review. Catal. Letters 2019, 149, 2204-2217. [CrossRef]

33. Steiner, K.; Schwab, H. Recent advances in rational approaches for enzyme engineering. Comput. Struct. Biotechnol. J. 2012, 2, e201209010. [CrossRef] [PubMed]

34. Porebski, B.T.; Buckle, A.M. Consensus protein design. Protein Eng. Des. Sel. 2016, 29, 245-251. [CrossRef] [PubMed]

35. Chen, Q.; Xiao, Y.; Zhang, W.; Mu, W. Current methods and applications in computational protein design for food industry. Crit. Rev. Food Sci. Nutr. 2019. In press. [CrossRef] [PubMed]

36. Wilding, M.; Hong, N.; Spence, M.; Buckle, A.M.; Jackson, C.J. Protein engineering: The potential of remote mutations. Biochem. Soc. Trans. 2019, 47, 701-711. [CrossRef] [PubMed]

37. Musil, M.; Konegger, H.; Hon, J.; Bednar, D.; Damborsky, J. Computational design of stable and soluble biocatalysts. ACS Catal. 2019, 9, 1033-1054. [CrossRef]

38. Bornscheuer, U.T.; Hauer, B.; Jaeger, K.E.; Schwaneberg, U. Directed evolution empowered redesign of natural proteins for the sustainable production of chemicals and pharmaceuticals. Angew. Chemie Int. Ed. 2019, 58, 36-40. [CrossRef]

39. Zeymer, C.; Hilvert, D. Directed evolution of protein catalysts. Annu. Rev. Biochem. 2018, 87, $131-157$. [CrossRef]

40. Arnold, F.H. Directed evolution: Bringing new chemistry to life. Angew. Chemie Int. Ed. 2018, 57, 4143-4148. [CrossRef]

41. Reetz, M.T. Directed Evolution of Selective Enzymes: Catalysts for Organic Chemistry and Biotechnology; Wiley-VCH Verlag GmbH \& Co. KGaA: Weinheim, Germany, 2016; ISBN 3527655484.

42. Qu, G.; Li, A.; Acevedo-Rocha, C.G.; Sun, Z.; Reetz, M.T. The crucial role of methodology development in directed evolution of selective enzymes. Angew. Chemie Int. Ed. 2019. [CrossRef]

43. Markel, U.; Essani, K.D.; Besirlioglu, V.; Schiffels, J.; Streit, W.R.; Schwaneberg, U. Advances in ultrahigh-throughput screening for directed enzyme evolution. Chem. Soc. Rev. 2020, 49, $233-262$. [CrossRef]

44. Sayous, V.; Lubrano, P.; Li, Y.; Acevedo-Rocha, C.G. Unbiased libraries in protein directed evolution. Biochim. Biophys. Acta Proteins Proteom. 2020, 1868, 140321. [CrossRef] [PubMed]

45. Arnold, F.H. Innovation by evolution: Bringing new chemistry to life (Nobel lecture). Angezw. Chemie Int. Ed. 2019, 58, 14420-14426. [CrossRef] [PubMed]

46. Baker, D. What has de novo protein design taught us about protein folding and biophysics? Protein Sci. 2019, 28, 678-683. [CrossRef]

47. Chowdhury, R.; Maranas, C.D. From directed evolution to computational enzyme engineering-A review. AIChE J. 2020, 66, e16847. [CrossRef]

48. Huang, P.-S.; Boyken, S.E.; Baker, D. The coming of age of de novo protein design. Nature 2016, 537, $320-327$. [CrossRef]

49. Korendovych, I.V.; DeGrado, W.F. De novo protein design, a retrospective. Q. Rev. Biophys. 2020, 53, e3. [CrossRef]

50. Mazurenko, S.; Prokop, Z.; Damborsky, J. Machine learning in enzyme engineering. ACS Catal. 2020, 10, 1210-1223. [CrossRef]

51. Eraslan, G.; Avsec, Ž.; Gagneur, J.; Theis, F.J. Deep learning: New computational modelling techniques for genomics. Nat. Rev. Genet. 2019, 20, 389-403. [CrossRef]

52. Han, X.; Wang, X.; Zhou, K. Develop machine learning-based regression predictive models for engineering protein solubility. Bioinformatics 2019, 35, 4640-4646. [CrossRef]

53. Li, G.; Dong, Y.; Reetz, M.T. Can machine learning revolutionize directed evolution of selective enzymes? Adv. Synth. Catal. 2019, 361, 2377-2386. [CrossRef] 
54. DeSantis, G.; Jones, J.B. Chemical modification of enzymes for enhanced functionality. Curr. Opin. Biotechnol. 1999, 10, 324-330. [CrossRef]

55. Cowan, D.A.; Fernandez-Lafuente, R. Enhancing the functional properties of thermophilic enzymes by chemical modification and immobilization. Enzyme Microb. Technol. 2011, 49, 326-346. [CrossRef] [PubMed]

56. Davis, B.G. Chemical modification of biocatalysts. Curr. Opin. Biotechnol. 2003, 14, 379-386. [CrossRef]

57. Díaz-Rodríguez, A.; Davis, B.G. Chemical modification in the creation of novel biocatalysts. Curr. Opin. Chem. Biol. 2011, 15, 211-219. [CrossRef]

58. Thompson, M.P.; Derrington, S.R.; Heath, R.S.; Porter, J.L.; Mangas-Sanchez, J.; Devine, P.N.; Truppo, M.D.; Turner, N.J. A generic platform for the immobilisation of engineered biocatalysts. Tetrahedron 2019, 75, 327-334. [CrossRef]

59. Ahmad, A.; Javed, M.R.; Ibrahim, M.; Sajid, A.; Hussain, K.; Kaleem, M.; Fatima, H.M.; Nadeem, H. Methods of enzyme immobilization on various supports. In Enzymatic Fuel Cells: Materials and Applications; Inamuddin, Ahmer, M.F., Ahamed, M.I., Asiri, A.M., Eds.; Materials Research Forum: Millersville, PA, USA, 2019; pp. 1-28.

60. Garcia-Galan, C.; Berenguer-Murcia, Á.; Fernandez-Lafuente, R.; Rodrigues, R.C. Potential of different enzyme immobilization strategies to improve enzyme performance. Adv. Synth. Catal. 2011, 353, 2885-2904. [CrossRef]

61. Rodrigues, R.C.; Ortiz, C.; Berenguer-Murcia, Á.; Torres, R.; Fernández-Lafuente, R. Modifying enzyme activity and selectivity by immobilization. Chem. Soc. Rev. 2013, 42, 6290-6307. [CrossRef]

62. Mateo, C.; Palomo, J.M.; Fernandez-Lorente, G.; Guisan, J.M.; Fernandez-Lafuente, R. Improvement of enzyme activity, stability and selectivity via immobilization techniques. Enzyme Microb. Technol. 2007, 40, 1451-1463. [CrossRef]

63. Sheldon, R.A.; van Pelt, S. Enzyme immobilization in biocatalysis: Why, what and how. Chem. Soc. Rev. 2013, 42, 6223-6235. [CrossRef]

64. Fernandez-Lafuente, R. Editorial for special issue: Enzyme immobilization and its applications. Molecules 2019, 24, 4619. [CrossRef]

65. Reis, C.L.B.; de Sousa, E.Y.A.; de Serpa, J.F.; Oliveira, R.C.; dos Santos, J.C.S. Design of immobilized enzyme biocatalysts: Drawbacks and opportunities. Quim. Nova 2019, 42, 768-783.

66. Thompson, M.P.; Peñafiel, I.; Cosgrove, S.C.; Turner, N.J. Biocatalysis using immobilized enzymes in continuous flow for the synthesis of fine chemicals. Org. Process Res. Dev. 2019, 23, 9-18. [CrossRef]

67. Grunwald, P. Immobilized biocatalysts. Catalysts 2018, 8, 386. [CrossRef]

68. Schmidt-Dannert, S.; Zhang, G.; Johnston, T.; Quin, M.B.; Schmidt-Dannert, C. Building a toolbox of protein scaffolds for future immobilization of biocatalysts. Appl. Microbiol. Biotechnol. 2018, 102, 8373-8388. [CrossRef]

69. Ren, S.; Li, C.; Jiao, X.; Jia, S.; Jiang, Y.; Bilal, M.; Cui, J. Recent progress in multienzymes co-immobilization and multienzyme system applications. Chem. Eng. J. 2019, 373, 1254-1278. [CrossRef]

70. Sheldon, R.A. CLEAs, combi-CLEASs and 'smart' magnetic CLEAs: Biocatalysis in a bio-based economy. Catalysts 2019, 9, 261. [CrossRef]

71. Priyanka, P.; Tan, Y.; Kinsella, G.K.; Henehan, G.T.; Ryan, B.J. Solvent stable microbial lipases: Current understanding and biotechnological applications. Biotechnol. Lett. 2019, 41, 203-220. [CrossRef]

72. Filho, D.G.; Silva, A.G.; Guidini, C.Z. Lipases: Sources, immobilization methods, and industrial applications. Appl. Microbiol. Biotechnol. 2019, 103, 7399-7423. [CrossRef]

73. Fernandez-Lorente, G.; Godoy, C.A.; Mendes, A.A.; Lopez-Gallego, F.; Grazu, V.; de las Rivas, B.; Palomo, J.M.; Hermoso, J.; Fernandez-Lafuente, R.; Guisan, J.M. Solid-phase chemical amination of a lipase from Bacillus thermocatenulatus to improve its stabilization via covalent immobilization on highly activated glyoxyl-agarose. Biomacromolecules 2008, 9, 2553-2561. [CrossRef]

74. de Godoy Daiha, K.; Angeli, R.; de Oliveira, S.D.; Almeida, R.V. Are lipases still important biocatalysts? A study of scientific publications and patents for technological forecasting. PLoS ONE 2015, 10, e0131624.

75. Dwivedee, B.P.; Soni, S.; Sharma, M.; Bhaumik, J.; Laha, J.K.; Banerjee, U.C. Promiscuity of lipase-catalyzed reactions for organic synthesis: A recent update. ChemistrySelect 2018, 3, 2441-2466. [CrossRef]

76. Monteiro, R.R.C.; Virgen-Ortiz, J.J.; Berenguer-Murcia, Á.; da Rocha, T.N.; dos Santos, J.C.S.; Alcántara, A.R.; Fernandez-Lafuente, R. Biotechnological relevance of the lipase A from Candida antarctica. Catal. Today 2020. In press. [CrossRef] 
77. Thangaraj, B.; Solomon, P.R. Immobilization of lipases-A review. Part II: Carrier materials. ChemBioEng Rev. 2019, 6, 167-194. [CrossRef]

78. Thangaraj, B.; Solomon, P.R. Immobilization of lipases-A review. Part I: Enzyme immobilization. ChemBioEng Rev. 2019, 6, 157-166. [CrossRef]

79. Facin, B.R.; Melchiors, M.S.; Valério, A.; Oliveira, J.V.; Oliveira, D. de Driving Immobilized lipases as biocatalysts: 10 years state of the art and future prospects. Ind. Eng. Chem. Res. 2019, 58, 5358-5378. [CrossRef]

80. del Monte-Martínez, A.; Cutiño-Avila, B.V.; González-Bacerio, J. Rational design strategy as a novel immobilization methodology applied to lipases and phospholipases. In Lipases and Phospholipases. Methods in Molecular Biology; Sandoval, G., Ed.; Humana Press: New York, NY, USA, 2018; pp. 243-283, ISBN 978-1-4939-8672-9.

81. Rodrigues, R.C.; Virgen-Ortíz, J.J.; dos Santos, J.C.S.; Berenguer-Murcia, Á.; Alcantara, A.R.; Barbosa, O.; Ortiz, C.; Fernandez-Lafuente, R. Immobilization of lipases on hydrophobic supports: Immobilization mechanism, advantages, problems, and solutions. Biotechnol. Adv. 2019, 37, 746-770. [CrossRef]

82. Matsumoto, T.; Yamada, R.; Ogino, H. Chemical treatments for modification and immobilization to improve the solvent-stability of lipase. World J. Microbiol. Biotechnol. 2019, 35, 193. [CrossRef]

83. Rodrigues, R.C.; Berenguer-Murcia, Á.; Fernandez-Lafuente, R. Coupling chemical modification and immobilization to improve the catalytic performance of enzymes. Adv. Synth. Catal. 2011, 353, $2216-2238$. [CrossRef]

84. Hernandez, K.; Fernandez-Lafuente, R. Control of protein immobilization: Coupling immobilization and site-directed mutagenesis to improve biocatalyst or biosensor performance. Enzyme Microb. Technol. 2011, 48, 107-122. [CrossRef]

85. Rueda, N.; dos Santos, J.C.S.; Ortiz, C.; Torres, R.; Barbosa, O.; Rodrigues, R.C.; Berenguer-Murcia, Á.; Fernandez-Lafuente, R. Chemical modification in the design of immobilized enzyme biocatalysts: Drawbacks and opportunities. Chem. Rec. 2016, 16, 1436-1455. [CrossRef]

86. Rodrigues, R.C.; Barbosa, O.; Ortiz, C.; Berenguer-Murcia, Á.; Torres, R.; Fernandez-Lafuente, R. Amination of enzymes to improve biocatalyst performance: Coupling genetic modification and physicochemical tools. RSC Adv. 2014, 4, 38350-38374. [CrossRef]

87. Fernandez-Lafuente, R. Stabilization of multimeric enzymes: Strategies to prevent subunit dissociation. Enzyme Microb. Technol. 2009, 45, 405-418. [CrossRef]

88. Santiago, G.; Martínez-Martínez, M.; Alonso, S.; Bargiela, R.; Coscolín, C.; Golyshin, P.N.; Guallar, V.; Ferrer, M. Rational engineering of multiple active sites in an ester hydrolase. Biochemistry 2018, 57, 2245-2255. [CrossRef] [PubMed]

89. Alonso, S.; Santiago, G.; Cea-Rama, I.; Fernandez-Lopez, L.; Coscolín, C.; Modregger, J.; Ressmann, A.K.; Martínez-Martínez, M.; Marrero, H.; Bargiela, R.; et al. Genetically engineered proteins with two active sites for enhanced biocatalysis and synergistic chemo- and biocatalysis. Nat. Catal. 2020, 3, 319-328. [CrossRef]

90. Quail, M.A.; Otto, T.D.; Gu, Y.; Harris, S.R.; Skelly, T.F.; McQuillan, J.A.; Swerdlow, H.P.; Oyola, S.O. Optimal enzymes for amplifying sequencing libraries. Nat. Methods 2012, 9, 10-11. [CrossRef]

91. Struvay, C.; Feller, G. Optimization to low temperature activity in psychrophilic enzymes. Int. J. Mol. Sci. 2012, 13, 11643-11665. [CrossRef]

92. Turner, B.L. Variation in ph optima of hydrolytic enzyme activities in tropical rain forest soils. Appl. Environ. Microbiol. 2010, 76, 6485-6493. [CrossRef]

93. de Oliveira Carvalho, J.; Orlanda, J.F.F. Heat stability and effect of $\mathrm{pH}$ on enzyme activity of polyphenol oxidase in buriti (Mauritia flexuosa Linnaeus f.) fruit extract. Food Chem. 2017, 233, 159-163. [CrossRef]

94. Herlet, J.; Kornberger, P.; Roessler, B.; Glanz, J.; Schwarz, W.H.; Liebl, W.; Zverlov, V. V A new method to evaluate temperature vs. $\mathrm{pH}$ activity profiles for biotechnological relevant enzymes. Biotechnol. Biofuels 2017, 10, 234. [CrossRef]

95. Krogdahl, Å.; Sundby, A.; Holm, H. Characteristics of digestive processes in Atlantic salmon (Salmo salar). Enzyme pH optima, chyme pH, and enzyme activities. Aquaculture 2015, 449, 27-36. [CrossRef]

96. Prieto, M.A.; Vazquez, J.A.; Murado, M.A. A new and general model to describe, characterize, quantify and classify the interactive effects of temperature and $\mathrm{pH}$ on the activity of enzymes. Analyst 2015, 140, 3587-3602. [CrossRef] [PubMed] 
97. Luo, H.; Zhu, L.; Chang, Y.; Liu, X.; Liu, Z.; Sun, H.; Li, X.; Yu, H.; Shen, Z. Microenvironmental pH changes in immobilized cephalosporin $C$ acylase during a proton-producing reaction and regulation by a two-stage catalytic process. Bioresour. Technol. 2017, 223, 157-165. [CrossRef] [PubMed]

98. Volpato, G.; Rodrigues, R.; Fernandez-Lafuente, R. Use of enzymes in the production of semi-synthetic penicillins and cephalosporins: Drawbacks and perspectives. Curr. Med. Chem. 2010, 17, 3855-3873. [CrossRef] [PubMed]

99. Boniello, C.; Mayr, T.; Klimant, I.; Koenig, B.; Riethorst, W.; Nidetzky, B. Intraparticle concentration gradients for substrate and acidic product in immobilized cephalosporin $C$ amidase and their dependencies on carrier characteristics and reaction parameters. Biotechnol. Bioeng. 2010, 106, 528-540. [CrossRef] [PubMed]

100. Fernández-Lafuente, R.; Rosell, C.M.; Piatkowska, B.; Guisán, J.M. Synthesis of antibiotics (cephaloglycin) catalyzed by penicillin $\mathrm{G}$ acylase: Evaluation and optimization of different synthetic approaches. Enzyme Microb. Technol. 1996, 19, 9-14. [CrossRef]

101. de Camargo, A.C.; Regitano-d'Arce, M.A.B.; Biasoto, A.C.T.; Shahidi, F. Enzyme-assisted extraction of phenolics from winemaking by-products: Antioxidant potential and inhibition of alpha-glucosidase and lipase activities. Food Chem. 2016, 212, 395-402. [CrossRef]

102. Bezerra, R.M.F.; Pinto, P.A.; Fraga, I.; Dias, A.A. Enzyme inhibition studies by integrated Michaelis-Menten equation considering simultaneous presence of two inhibitors when one of them is a reaction product. Comput. Methods Programs Biomed. 2016, 125, 2-7. [CrossRef]

103. Cleland, W.W. The kinetics of enzyme-catalyzed reactions with two or more substrates or products: II. Inhibition: Nomenclature and theory. Biochim. Biophys. Acta Spec. Sect. Enzymol. Subj. 1963, 67, 173-187.

104. Andrades, D.; Graebin, N.G.; Kadowaki, M.K.; Ayub, M.A.Z.; Fernandez-Lafuente, R.; Rodrigues, R.C. Immobilization and stabilization of different $\beta$-glucosidases using the glutaraldehyde chemistry: Optimal protocol depends on the enzyme. Int. J. Biol. Macromol. 2019, 129, 672-678. [CrossRef]

105. de Andrades, D.; Graebin, N.G.; Ayub, M.A.Z.; Fernandez-Lafuente, R.; Rodrigues, R.C. Physico-chemical properties, kinetic parameters, and glucose inhibition of several beta-glucosidases for industrial applications. Process Biochem. 2019, 78, 82-90. [CrossRef]

106. Avinash, V.S.; Panigrahi, P.; Suresh, C.G.; Pundle, A.V.; Ramasamy, S. Structural modelling of substrate binding and inhibition in penicillin $\mathrm{V}$ acylase from Pectobacterium atrosepticum. Biochem. Biophys. Res. Commun. 2013, 437, 538-543. [CrossRef] [PubMed]

107. Pessela, B.C.C.; Mateo, C.; Fuentes, M.; Vian, A.; García, J.L.; Carrascosa, A.V.; Guisán, J.M.; Fernández-Lafuente, R. The immobilization of a thermophilic $\beta$-galactosidase on Sepabeads supports decreases product inhibition: Complete hydrolysis of lactose in dairy products. Enzyme Microb. Technol. 2003, 33, 199-205. [CrossRef]

108. Cleland, W.W. The kinetics of enzyme-catalyzed reactions with two or more substrates or products: III. Prediction of initial velocity and inhibition patterns by inspection. Biochim. Biophys. Acta Spec. Sect. Enzymol. Subj. 1963, 67, 188-196.

109. Mateo, C.; Monti, R.; Pessela, B.C.C.; Fuentes, M.; Torres, R.; Manuel Guisán, J.; Fernández-Lafuente, R. Immobilization of lactase from Kluyveromyces lactis greatly reduces the inhibition promoted by glucose. Full hydrolysis of lactose in milk. Biotechnol. Prog. 2004, 20, 1259-1262. [CrossRef] [PubMed]

110. Crameri, A.; Raillard, S.-A.; Bermudez, E.; Stemmer, W.P.C. DNA shuffling of a family of genes from diverse species accelerates directed evolution. Nature 1998, 391, 288-291. [CrossRef] [PubMed]

111. Romero, P.A.; Arnold, F.H. Exploring protein fitness landscapes by directed evolution. Nat. Rev. Mol. Cell Biol. 2009, 10, 866-876. [CrossRef]

112. Cherry, J.R.; Fidantsef, A.L. Directed evolution of industrial enzymes: An update. Curr. Opin. Biotechnol. 2003, 14, 438-443. [CrossRef]

113. Pereira, S.A.P.; Dyson, P.J.; Saraiva, M.L.M.F.S. Miniaturized technologies for high-throughput drug screening enzymatic assays and diagnostics-A review. TrAC Trends Anal. Chem. 2020, 126, 115862. [CrossRef]

114. Shan, X.; Liu, L.; Zeng, W.; Chen, J.; Zhou, J. High throughput screening platform for a FAD-dependent L-sorbose sehydrogenase. Front. Bioeng. Biotechnol. 2020, 8, 194. [CrossRef] [PubMed]

115. Fan, F.; Wood, K. Bioluminescent assays for high-throughput screening. Assay Drug Dev. Technol. 2007, 5, 127-136. [CrossRef] 
116. Inglese, J.; Auld, D.; Jadhav, A.; Johnson, R.; Simeonov, A.; Yasgar, A.; Zheng, W.; Austin, C. Quantitative high-throughput screening: A titration-based approach that efficiently identifies biological activities in large chemical libraries. Proc. Natl. Acad. Sci. USA. 2006, 103, 11473-11478. [CrossRef] [PubMed]

117. Drueckhammer, D.G.; Hennen, W.J.; Pederson, R.L.; Iii, C.F.B.; Gautheron, C.M.; Krach, T.; Wong, C.H. Enzyme catalysis in synthetic carbohydrate chemistry. Synthesis 1991, 1991, 499-525. [CrossRef]

118. do Nascimento, M.A.; Gotardo, L.E.; Bastos, E.M.; Almeida, F.C.L.; Leão, R.A.C.; de Souza, R.O.M.A.; Wojcieszak, R.; Itabaiana, I. Regioselective acylation of levoglucosan catalyzed by Candida antarctica (CaLB) lipase immobilized on epoxy resin. Sustainability 2019, 11, 6044. [CrossRef]

119. Riva, S.; Chopineau, J.; Kieboom, A.P.G.; Klibanov, A.M. Protease-catalyzed regioselective esterification of sugars and related compounds in anhydrous dimethylformamide. J. Am. Chem. Soc. 1988, 110, 584-589. [CrossRef]

120. Therisod, M.; Klibanov, A.M. Regioselective acylation of secondary hydroxyl groups in sugars catalyzed by lipases in organic solvents. J. Am. Chem. Soc. 1987, 109, 3977-3981. [CrossRef]

121. Ren, B.; Zhang, L.; Zhang, M. Progress on selective acylation of carbohydrate hydroxyl groups. As. J. Org. Chem. 2019, 8, 1813-1823. [CrossRef]

122. De Ruysscher, D.; Pang, L.; De Graef, S.; Nautiyal, M.; De Borggraeve, W.M.; Rozenski, J.; Strelkov, S.V.; Weeks, S.D.; Van Aerschot, A. Acylated sulfonamide adenosines as potent inhibitors of the adenylate-forming enzyme superfamily. Eur. J. Med. Chem. 2019, 174, 252-264. [CrossRef]

123. Liu, M.; Kong, J.-Q. The enzymatic biosynthesis of acylated steroidal glycosides and their cytotoxic activity. Acta Pharm. Sin. B 2018, 8, 981-994. [CrossRef]

124. Yang, J.; Liu, Y.; Liang, X.; Yang, Y.; Li, Q. Enantio-, regio-, and chemoselective lipase-catalyzed polymer synthesis. Macromol. Biosci. 2018, 18, 1800131. [CrossRef]

125. Du, L.; Jiang, Z.; Xu, L.; Zhou, N.; Shen, J.; Dong, Z.; Shen, L.; Wang, H.; Luo, X. Microfluidic reactor for lipase-catalyzed regioselective synthesis of neohesperidin ester derivatives and their antimicrobial activity research. Carbohydr. Res. 2018, 455, 32-38. [CrossRef]

126. Li, X.; Xu, H.; Zhao, G.; Wu, H.; Yu, Y.; Lai, F.; Xiao, X. Highly efficient synthesis of arbutin esters catalyzed by whole cells of Candida parapsilosis. RSC Adv. 2018, 8, 10081-10088. [CrossRef]

127. Inprakhon, P.; Wongthongdee, N.; Amornsakchai, T.; Pongtharankul, T.; Sunintaboon, P.; Wiemann, L.O.; Durand, A.; Sieber, V. Lipase-catalyzed synthesis of sucrose monoester: Increased productivity by combining enzyme pretreatment and non-aqueous biphasic medium. J. Biotechnol. 2017, 259, 182-190. [CrossRef] [PubMed]

128. Wang, Y.F.; Lalonde, J.J.; Momongan, M.; Bergbreiter, D.E.; Wong, C.H. Lipase-catalyzed irreversible transesterifications using enol esters as acylating reagents: Preparative enantio- and regioselective syntheses of alcohols, glycerol derivatives, sugars and organometallics. J. Am. Chem. Soc. 1988, 110, 7200-7205. [CrossRef]

129. Matsumura, S.; Maeda, S.; Yoshikawa, S. Molecular design of biodegradable poly(carboxylic acid). Polym. Mater. Sci. Eng. Proc. ACS Div. Polym. Mater. Sci. Eng. 1989, 60, 885.

130. Corey, E.J. The mechanism of the decarboxylation of $\alpha, \beta$ - and $\beta, \gamma$-unsaturated malonic acid derivatives and the course of decarboxylative condensation reactions in pyridine. J. Am. Chem. Soc. 1952, 74, 5897-5905. [CrossRef]

131. Albers, T.; Biagini, S.C.G.; Hibbs, D.E.; Hursthouse, M.B.; Malik, K.M.A.; North, M.; Uriarte, E.; Zagotto, G. Desymmetrisation of meso-anhydrides utilising (S)-proline derivatives. Synthesis 1996, 1996, 393-398. [CrossRef]

132. Galston, A.W.; Sawhney, R.K. Polyamines in plant physiology. Plant Physiol. 1990, 94, 406-410. [CrossRef]

133. Jänne, J.; Alhonen, L.; Leinonen, P. Polyamines: From molecular biology to clinical applications. Ann. Med. 1991, 23, 241-259. [CrossRef]

134. Park, S.; Kazlauskas, R.J. Improved preparation and use of room-temperature ionic liquids in lipase-catalyzed enantio- and regioselective acylations. J. Org. Chem. 2001, 66, 8395-8401. [CrossRef]

135. Kennedy, J.F.; Kumar, H.; Panesar, P.S.; Marwaha, S.S.; Goyal, R.; Parmar, A.; Kaur, S. Enzyme-catalyzed regioselective synthesis of sugar esters and related compounds. J. Chem. Technol. Biotechnol. 2006, 81, 866-876. [CrossRef]

136. Nakamura, K.; Yamanaka, R.; Matsuda, T.; Harada, T. Recent developments in asymmetric reduction of ketones with biocatalysts. Tetrahedron. Asymmetry 2003, 14, 2659-2681. [CrossRef] 
137. Pellissier, H. Asymmetric domino reactions. Part B: Reactions based on the use of chiral catalysts and biocatalysts. Tetrahedron 2006, 62, 2143-2173. [CrossRef]

138. Matsuda, T.; Yamanaka, R.; Nakamura, K. Recent progress in biocatalysis for asymmetric oxidation and reduction. Tetrahedron Asymmetry 2009, 20, 513-557. [CrossRef]

139. Niwa, T.; Murayama, N.; Imagawa, Y.; Yamazaki, H. Regioselective hydroxylation of steroid hormones by human cytochromes P450. Drug Metab. Rev. 2015, 47, 89-110. [CrossRef] [PubMed]

140. Schnepel, C.; Sewald, N. Enzymatic Halogenation: A Timely strategy for regioselective C-H activation. Chem. A Eur. J. 2017, 23, 12064-12086. [CrossRef]

141. Chen, Z.; Zhao, J.; Jiang, S.; Wei, D. Recent research advancements on regioselective nitrilase: Fundamental and applicative aspects. Appl. Microbiol. Biotechnol. 2019, 103, 6393-6405. [CrossRef]

142. Filice, M.; Molina, M.; Benaiges, M.D.; Abian, O.; Valero, F.; Palomo, J.M. Solid-surface activated recombinant Rhizopous oryzae lipase expressed in Pichia pastoris and chemically modified variants as efficient catalysts in the synthesis of hydroxy monodeprotected glycals. Catal. Sci. Technol. 2017, 7, 1766-1775. [CrossRef]

143. Brabcová, J.; Blažek, J.; Krečmerová, M.; Vondrášek, J.; Palomo, J.; Zarevúcka, M. Regioselective palmitoylation of 9-(2,3-dihydroxy- propyl)adenine catalyzed by a glycopolymer-enzyme conjugate. Molecules 2016, 21, 648. [CrossRef]

144. Vavříková, E.; Gavezzotti, P.; Purchartová, K.; Fuksová, K.; Biedermann, D.; Kuzma, M.; Riva, S.; Křen, V. Regioselective alcoholysis of silychristin acetates catalyzed by lipases. Int. J. Mol. Sci. 2015, 16, 11983-11995. [CrossRef]

145. da Silva, M.R.; Montenegro, T.G.C.; de Mattos, M.C.; de Oliveira, M.d.C.F.; de Lemos, T.L.G.; de Gonzalo, G.; Lavandera, I.; Gotor-Fernández, V.; Gotor, V. Regioselective preparation of thiamphenicol esters through lipase-catalyzed processes. J. Braz. Chem. Soc. 2014, 25, 987-994.

146. Cabrera, Z.; Palomo, J.M.; Fernandez-Lorente, G.; Fernandez-Lafuente, R.; Guisan, J.M. Partial and enantioselective hydrolysis of diethyl phenylmalonate by immobilized preparations of lipase from Thermomyces lanuginose. Enzyme Microb. Technol. 2007, 40, 1280-1285. [CrossRef]

147. Cabrera, Z.; Lopez-Gallego, F.; Fernandez-Lorente, G.; Palomo, J.M.; Montes, T.; Grazu, V.; Guisán, J.M.; Fernández-Lafuente, R. Asymmetric hydrolysis of dimethyl phenylmalonate by immobilized penicillin G acylase from E. coli. Enzyme Microb. Technol. 2007, 40, 997-1000. [CrossRef]

148. Jiang, Y.; Wang, C.; Ma, N.; Chen, J.; Liu, C.; Wang, F.; Xu, J.; Cong, Z. Regioselective aromatic O-demethylation with an artificial P450BM3 peroxygenase system. Catal. Sci. Technol. 2020, 10, 1219-1223. [CrossRef]

149. Guarneri, A.; Westphal, A.H.; Leertouwer, J.; Lunsonga, J.; Franssen, M.C.R.; Opperman, D.J.; Hollmann, F.; van Berkel, W.J.H.; Paul, C.E. Flavoenzyme-mediated regioselective aromatic hydroxylation with coenzyme biomimetics. Chem CatChem 2020, 12, 1368-1375. [CrossRef]

150. Hu, D.; Zong, X.-C.; Xue, F.; Li, C.; Hu, B.-C.; Wu, M.-C. Manipulating regioselectivity of an epoxide hydrolase for single enzymatic synthesis of (R)-1,2-diols from racemic epoxides. Chem. Commun. 2020, 56, 2799-2802. [CrossRef]

151. Wan, N.; Zhou, X.; Ma, R.; Tian, J.; Wang, H.; Cui, B.; Han, W.; Chen, Y. Synthesis of chiral 5-aryl-2-oxazolidinones via halohydrin dehalogenase-catalyzed enantio- and regioselective ring-opening of styrene oxides. Adv. Synth. Catal. 2020, 362, 1201-1207. [CrossRef]

152. Pereira, P.R.M.; de Araújo, J.O.; Silva, J.R.A.; Alves, C.N.; Lameira, J.; Lima, A.H. Exploring chloride selectivity and halogenase regioselectivity of the sall enzyme through quantum mechanical/molecular mechanical modeling. J. Chem. Inf. Model. 2020, 60, 738-746. [CrossRef] [PubMed]

153. Hernandez, K.; Garcia-Verdugo, E.; Porcar, R.; Fernandez-Lafuente, R. Hydrolysis of triacetin catalyzed by immobilized lipases: Effect of the immobilization protocol and experimental conditions on diacetin yield. Enzyme Microb. Technol. 2011, 48, 510-517. [CrossRef]

154. Hirata, D.B.; Albuquerque, T.L.; Rueda, N.; Virgen-Ortíz, J.J.; Tacias-Pascacio, V.G.; Fernandez-Lafuente, R. Evaluation of different immobilized lipases in transesterification reactions using tributyrin: Advantages of the heterofunctional octyl agarose beads. J. Mol. Catal. B Enzym. 2016, 133, 117-123. [CrossRef]

155. Hirata, D.B.; Albuquerque, T.L.; Rueda, N.; Sánchez-Montero, J.M.; Garcia-Verdugo, E.; Porcar, R.; Fernandez-Lafuente, R. Advantages of heterofunctional octyl supports: Production of 1,2-dibutyrin by specific and selective hydrolysis of tributyrin catalyzed by immobilized lipases. ChemistrySelect 2016, 1, 3259-3270. [CrossRef] 
156. Wang, J.; Liu, X.; Wang, X.-D.; Dong, T.; Zhao, X.-Y.; Zhu, D.; Mei, Y.-Y.; Wu, G.-H. Selective synthesis of human milk fat-style structured triglycerides from microalgal oil in a microfluidic reactor packed with immobilized lipase. Bioresour. Technol. 2016, 220, 132-141. [CrossRef] [PubMed]

157. Eichmann, T.O.; Kumari, M.; Haas, J.T.; Farese, R.V.; Zimmermann, R.; Lass, A.; Zechner, R. Studies on the substrate and stereo/regioselectivity of adipose triglyceride lipase, hormone-sensitive lipase, and diacylglycerol-O-acyltransferases. J. Biol. Chem. 2012, 287, 41446-41457. [CrossRef] [PubMed]

158. Rogalska, E.; Cudrey, C.; Ferrato, F.; Verger, R. Stereoselective hydrolysis of triglycerides by animal and microbial lipases. Chirality 1993, 5, 24-30. [CrossRef] [PubMed]

159. Rogalska, E.; Ransac, S.; Verger, R. Stereoselectivity of lipases. II. Stereoselective hydrolysis of triglycerides by gastric and pancreatic lipases. J. Biol. Chem. 1990, 265, 20271-20276.

160. Rodrigues, R.C.; Ayub, M.A.Z. Effects of the combined use of Thermomyces lanuginosus and lipases for the transesterification and hydrolysis of soybean oil. Process Biochem. 2011, 46, 682-688. [CrossRef]

161. Lee, D.H.; Kim, J.M.; Shin, H.Y.; Kang, S.W.; Kim, S.W. Biodiesel production using a mixture of immobilized Rhizopus oryzae and Candida rugosa lipases. Biotechnol. Bioprocess Eng. 2006, 11, 522-525. [CrossRef]

162. Tan, J.-N.; Dou, Y. Deep eutectic solvents for biocatalytic transformations: Focused lipase-catalyzed organic reactions. Appl. Microbiol. Biotechnol. 2020, 104, 1481-1496. [CrossRef]

163. Bharathi, D.; Rajalakshmi, G. Microbial lipases: An overview of screening, production and purification. Biocatal. Agric. Biotechnol. 2019, 22, 101368. [CrossRef]

164. Hasan, F.; Shah, A.A.; Hameed, A. Industrial applications of microbial lipases. Enzyme Microb. Technol. 2006, 39, 235-251. [CrossRef]

165. Ching-Velasquez, J.; Fernández-Lafuente, R.; Rodrigues, R.C.; Plata, V.; Rosales-Quintero, A.; Torrestiana-Sánchez, B.; Tacias-Pascacio, V.G. Production and characterization of biodiesel from oil of fish waste by enzymatic catalysis. Renew. Energy 2020, 153, 1346-1354. [CrossRef]

166. Mendoza-Ortiz, P.A.; Gama, R.S.; Gómez, O.C.; Luiz, J.H.H.; Fernandez-Lafuente, R.; Cren, E.C.; Mendes, A.A. Sustainable enzymatic synthesis of a solketal ester-Process optimization and evaluation of its antimicrobial activity. Catalysts 2020, 10, 218. [CrossRef]

167. Zieniuk, B.; Fabiszewska, A.; Białecka-Florjańczyk, E. Screening of solvents for favoring hydrolytic activity of Candida antarctica lipase B. Bioprocess Biosyst. Eng. 2020, 43, 605-613. [CrossRef] [PubMed]

168. Zou, X.; Nadege, K.; Ninette, I.; Wen, Y.; Wu, S.; Jiang, X.; Zhang, H.; Jin, Q.; Wang, X. Preparation of docosahexaenoic acid-rich diacylglycerol-rich oil by lipase-catalyzed glycerolysis of microbial oil from Schizochytrium sp. in a solvent-free system. J. Am. Oil Chem. Soc. 2020, 97, 263-270. [CrossRef]

169. Bayout, I.; Bouzemi, N.; Guo, N.; Mao, X.; Serra, S.; Riva, S.; Secundo, F. Natural flavor ester synthesis catalyzed by lipases. Flavour Fragr. J. 2020, 35, 209-218. [CrossRef]

170. Fernandes, K.V.; Cavalcanti, E.D.C.; Cipolatti, E.P.; Aguieiras, E.C.G.; Pinto, M.C.C.; Tavares, F.A.; da Silva, P.R.; Fernandez-Lafuente, R.; Arana-Peña, S.; Pinto, J.C.; et al. Enzymatic synthesis of biolubricants from by-product of soybean oil processing catalyzed by different biocatalysts of Candida rugosa lipase. Catal. Today 2020. In press. [CrossRef]

171. Monteiro, R.R.C.; Neto, D.M.A.; Fechine, P.B.A.; Lopes, A.A.S.; Gonçalves, L.R.B.; dos Santos, J.C.S.; de Souza, M.C.M.; Fernandez-Lafuente, R. Ethyl butyrate synthesis catalyzed by lipases A and B from Candida antarctica immobilized onto magnetic nanoparticles. Improvement of biocatalysts' performance under ultrasonic irradiation. Int. J. Mol. Sci. 2019, 20, 5807. [CrossRef]

172. Barsé, L.Q.; Graebin, N.G.; Cipolatti, E.P.; Robert, J.M.; Pinto, M.C.C.; Pinto, J.C.C.S.; Freire, D.M.G.; Rodrigues, R.C. Production and optimization of isopropyl palmitate via biocatalytic route using home-made enzymatic catalysts. J. Chem. Technol. Biotechnol. 2019, 94, 389-397. [CrossRef]

173. Fukuda, H.; Kondo, A.; Noda, H. Biodiesel fuel production by transesterification of oils. J. Biosci. Bioeng. 2001, 92, 405-416. [CrossRef]

174. Xu, X. Production of specific-structured triacylglycerols by lipase-catalyzed reactions: A review. Eur. J. Lipid Sci. Technol. 2000, 102, 287-303. [CrossRef]

175. Malcata, F.X.; Reyes, H.R.; Garcia, H.S.; Hill, C.G.; Amundson, C.H. Kinetics and mechanisms of reactions catalysed by immobilized lipases. Enzyme Microb. Technol. 1992, 14, 426-446. [CrossRef]

176. Bornscheuer, U.T.; Bessler, C.; Srinivas, R.; Hari Krishna, S. Optimizing lipases and related enzymes for efficient application. Trends Biotechnol. 2002, 20, 433-437. [CrossRef] 
177. Abed, S.M.; Elbandy, M.; Abdel-Samie, M.A.; Ali, A.H.; Korma, S.A.; Noman, A.; Wei, W.; Jin, Q. Screening of lipases for production of novel structured lipids from single cell oils. Process Biochem. 2020, 91, 181-188. [CrossRef]

178. Hult, K.; Berglund, P. Enzyme promiscuity: Mechanism and applications. Trends Biotechnol. 2007, 25, $231-238$. [CrossRef] [PubMed]

179. Kapoor, M.; Gupta, M.N. Lipase promiscuity and its biochemical applications. Process Biochem. 2012, 47, 555-569. [CrossRef]

180. Brzozowski, A.M.; Derewenda, U.; Derewenda, Z.S.; Dodson, G.G.; Lawson, D.M.; Turkenburg, J.P.; Bjorkling, F.; Huge-Jensen, B.; Patkar, S.A.; Thim, L. A model for interfacial activation in lipases from the structure of a fungal lipase-inhibitor complex. Nature 1991, 351, 491-494. [CrossRef] [PubMed]

181. Verger, R. 'Interfacial activation' of lipases: Facts and artifacts. Trends Biotechnol. 1997, 15, 32-38. [CrossRef]

182. Khan, F.I.; Lan, D.; Durrani, R.; Huan, W.; Zhao, Z.; Wang, Y. The lid domain in lipases: Structural and functional determinant of enzymatic properties. Front. Bioeng. Biotechnol. 2017, 5, 16. [CrossRef]

183. Kumar, A.; Dhar, K.; Kanwar, S.S.; Arora, P.K. Lipase catalysis in organic solvents: Advantages and applications. Biol. Proced. Online 2016, 18, 2. [CrossRef]

184. Borrelli, G.M.; Trono, D. Recombinant lipases and phospholipases and their use as biocatalysts for industrial applications. Int. J. Mol. Sci. 2015, 16, 20774-20840. [CrossRef]

185. Misra, N.N.; Pankaj, S.K.; Segat, A.; Ishikawa, K. Cold plasma interactions with enzymes in foods and model systems. Trends Food Sci. Technol. 2016, 55, 39-47. [CrossRef]

186. Khan, N.R.; Rathod, V.K. Enzyme catalyzed synthesis of cosmetic esters and its intensification: A review. Process Biochem. 2015, 50, 1793-1806. [CrossRef]

187. Carvalho, A.; Fonseca, T.; Mattos, M.; Oliveira, M.; Lemos, T.; Molinari, F.; Romano, D.; Serra, I. Recent advances in lipase-mediated preparation of pharmaceuticals and their intermediates. Int. J. Mol. Sci. 2015, 16, 29682-29716. [CrossRef] [PubMed]

188. Kim, B.H.; Akoh, C.C. Recent research trends on the enzymatic synthesis of structured lipids. J. Food Sci. 2015, 80, C1713-C1724. [CrossRef] [PubMed]

189. Sarmah, N.; Revathi, D.; Sheelu, G.; Yamuna Rani, K.; Sridhar, S.; Mehtab, V.; Sumana, C. Recent advances on sources and industrial applications of lipases. Biotechnol. Prog. 2018, 34, 5-28. [CrossRef]

190. Neta, N.S.; Teixeira, J.A.; Rodrigues, L.R. Sugar ester surfactants: Enzymatic synthesis and applications in food industry. Crit. Rev. Food Sci. Nutr. 2015, 55, 595-610. [CrossRef]

191. Lopresto, C.G.; Naccarato, S.; Albo, L.; De Paola, M.G.; Chakraborty, S.; Curcio, S.; Calabrò, V. Enzymatic transesterification of waste vegetable oil to produce biodiesel. Ecotoxicol. Environ. Saf. 2015, 121, 229-235. [CrossRef]

192. Craven, R.J.; Lencki, R.W. Symmetry, chirality and crystalline tendency: The polymorphism of triacylglycerols. Food Funct. 2012, 3, 228-233. [CrossRef]

193. Hsu, F.-F.; Turk, J. Structural characterization of triacylglycerols as lithiated adducts by electrospray ionization mass spectrometry using low-energy collisionally activated dissociation on a triple stage quadrupole instrument. J. Am. Soc. Mass Spectrom. 1999, 10, 587-599. [CrossRef]

194. Mu, H.; Porsgaard, T. The metabolism of structured triacylglycerols. Prog. Lipid Res. 2005, 44, 430-448. [CrossRef]

195. Cheng, C.; Gross, M.L.; Pittenauer, E. Complete structural elucidation of triacylglycerols by tandem sector mass spectrometry. Anal. Chem. 1998, 70, 4417-4426. [CrossRef]

196. Zarai, Z.; Eddehech, A.; Rigano, F.; Oteri, M.; Micalizzi, G.; Dugo, P.; Mondello, L.; Cacciola, F. Characterization of monoacylglycerols and diacylglycerols rich in polyunsaturated fatty acids produced by hydrolysis of Musteleus mustelus liver oil catalyzed by an immobilized bacterial lipase. J. Chromatogr. A 2020, 1613, 460692. [CrossRef] [PubMed]

197. Monte Blanco, S.F.M.; Santos, J.S.; Feltes, M.M.C.; Dors, G.; Licodiedoff, S.; Lerin, L.A.; de Oliveira, D.; Ninow, J.L.; Furigo, A. Optimization of diacylglycerol production by glycerolysis of fish oil catalyzed by Lipozyme TL IM with Tween 65. Bioprocess Biosyst. Eng. 2015, 38, 2379-2388. [CrossRef] [PubMed]

198. Xia, Q.; Akanbi, T.O.; Li, R.; Wang, B.; Yang, W.; Barrow, C.J. Lipase-catalysed synthesis of palm oil-omega-3 structured lipids. Food Funct. 2019, 10, 3142-3149. [CrossRef] [PubMed] 
199. Mota, D.A.; Rajan, D.; Heinzl, G.C.; Osório, N.M.; Gominho, J.; Krause, L.C.; Soares, C.M.F.; Nampoothiri, K.M.; Sukumaran, R.K.; Ferreira-Dias, S. Production of low-calorie structured lipids from spent coffee grounds or olive pomace crude oils catalyzed by immobilized lipase in magnetic nanoparticles. Bioresour. Technol. 2020, 307, 123223. [CrossRef]

200. Moharana, T.R.; Rao, N.M. Substrate structure and computation guided engineering of a lipase for omega-3 fatty acid selectivity. PLoS ONE 2020, 15, e0231177. [CrossRef]

201. Chen, M.; Gao, X.; Yang, W.; Sun, C.; Yang, J.; Zhang, H.; Song, Y. Discovery and characterization of a stable lipase with preference toward long-chain fatty acids. Biotechnol. Lett. 2020, 42, 171-180. [CrossRef]

202. Cao, X.; Liao, L.; Feng, F. Purification and characterization of an extracellular lipase from Trichosporon sp. and its application in enrichment of omega-3 polyunsaturated fatty acids. LWT 2020, 118, 108692. [CrossRef]

203. Saario, S.M.; Laitinen, J.T. Monoglyceride lipase as an enzyme hydrolyzing 2-arachidonoylglycerol. Chem. Biodivers. 2007, 4, 1903-1913. [CrossRef]

204. Bornscheuer, U.T. Lipase-catalyzed syntheses of monoacylglycerols. Enzyme Microb. Technol. 1995, 17, 578-586. [CrossRef]

205. Yuan, D.; Wu, Z.; Wang, Y. Evolution of the diacylglycerol lipases. Prog. Lipid Res. 2016, 64, 85-97. [CrossRef]

206. Lee, W.J.; Zhang, Z.; Lai, O.M.; Tan, C.P.; Wang, Y. Diacylglycerol in food industry: Synthesis methods, functionalities, health benefits, potential risks and drawbacks. Trends Food Sci. Technol. 2020, 97, 114-125. [CrossRef]

207. Wang, X.; Cheng, Y.; Jin, Q.; Wei, W.; Wang, X. Biocatalytic synthesis and characterization of sn- $1 / 3$ and sn-2 monoacylglycerols. Biotechnol. Lett. 2019, 41, 789-799. [CrossRef] [PubMed]

208. Yang, T.; Fruekilde, M.-B.; Xu, X. Suppression of acyl migration in enzymatic production of structured lipids through temperature programming. Food Chem. 2005, 92, 101-107. [CrossRef]

209. Filice, M.; Bavaro, T.; Fernandez-Lafuente, R.; Pregnolato, M.; Guisan, J.M.; Palomo, J.M.; Terreni, M. Chemo-biocatalytic regioselective one-pot synthesis of different deprotected monosaccharides. Catal. Today 2009, 140, 11-18. [CrossRef]

210. Li, W.; Du, W.; Li, Q.; Sun, T.; Liu, D. Study on acyl migration kinetics of partial glycerides: Dependence on temperature and water activity. J. Mol. Catal. B Enzym. 2010, 63, 17-22. [CrossRef]

211. Cao, X.; Mangas-Sánchez, J.; Feng, F.; Adlercreutz, P. Acyl migration in enzymatic interesterification of triacylglycerols: Effects of lipases from Thermomyces lanuginosus and Rhizopus oryzae, support material, and water activity. Eur. J. Lipid Sci. Technol. 2016, 118, 1579-1587. [CrossRef]

212. Peng, B.; Chen, F.; Liu, X.; Hu, J.-N.; Zheng, L.-F.; Li, J.; Deng, Z.-Y. Trace water activity could improve the formation of 1,3-oleic-2-medium chain-rich triacylglycerols by promoting acyl migration in the lipase RM IM catalyzed interesterification. Food Chem. 2020, 313, 126130. [CrossRef]

213. Li, W.; Du, W.; Li, Q.; Li, R.; Liu, D. Dependence on the properties of organic solvent: Study on acyl migration kinetics of partial glycerides. Bioresour. Technol. 2010, 101, 5737-5742. [CrossRef]

214. Mao, J.; Hu, Z.; Hu, J.; Zhu, X.; Xiong, H. A density functional theory (DFT) study of the acyl migration occurring during lipase-catalyzed transesterifications. Int. J. Mol. Sci. 2019, 20, 3438. [CrossRef]

215. Oda, M.; Kaieda, M.; Hama, S.; Yamaji, H.; Kondo, A.; Izumoto, E.; Fukuda, H. Facilitatory effect of immobilized lipase-producing Rhizopus oryzae cells on acyl migration in biodiesel-fuel production. Biochem. Eng. J. 2005, 23, 45-51. [CrossRef]

216. Xu, X.; Balchen, S.; Høy, C.-E.; Adler-Nissen, J. Pilot batch production of specific-structured lipids by lipase-catalyzed interesterification: Preliminary study on incorporation and acyl migration. J. Am. Oil Chem. Soc. 1998, 75, 301-308. [CrossRef]

217. Briand, D.; Dubreucq, E.; Galzy, P. Functioning and regioselectivity of the lipase of Candida parapsilosis (Ashford) langeron and talice in aqueous medium: New interpretation of regioselectivity taking acyl migration into account. Eur. J. Biochem. 1995, 228, 169-175. [CrossRef] [PubMed]

218. Liu, K.K.-C.; Nozaki, K.; Wong, C.-H. Problems of acyl migration in lipase-catalyzed enantioselective transformation of meso-1,3-diol systems. Biocatal. Biotransformation 1990, 3, 169-177.

219. Kim, B.H.; Akoh, C.C. Modeling of lipase-catalyzed acidolysis of sesame oil and caprylic acid by response surface methodology: Optimization of reaction conditions by considering both acyl incorporation and migration. J. Agric. Food Chem. 2005, 53, 8033-8037. [CrossRef] 
220. Kaieda, M.; Samukawa, T.; Matsumoto, T.; Ban, K.; Kondo, A.; Shimada, Y.; Noda, H.; Nomoto, F.; Ohtsuka, K.; Izumoto, E.; et al. Biodiesel fuel production from plant oil catalyzed by Rhizopus oryzae lipase in a water-containing system without an organic solvent. J. Biosci. Bioeng. 1999, 88, 627-631. [CrossRef]

221. Li, W.; Li, R.; Li, Q.; Du, W.; Liu, D. Acyl migration and kinetics study of 1(3)-positional specific lipase of Rhizopus oryzae-catalyzed methanolysis of triglyceride for biodiesel production. Process Biochem. 2010, 45, 1888-1893. [CrossRef]

222. Walia, S.; Mukhia, S.; Bhatt, V.; Kumar, R.; Kumar, R. Variability in chemical composition and antimicrobial activity of Tagetes minuta L. essential oil collected from different locations of Himalaya. Ind. Crops Prod. 2020, 150, 112449. [CrossRef]

223. da Silva, C.M.; Zanqui, A.B.; Visentainer, J.V.; Cardozo-Filho, L.; Bittencourt, P.R.S.; Morais, D.R.; Santos, J.M.; Eberlin, M.N.; Matsushita, M. Quality and composition of three palm oils isolated by clean and sustainable process. J. Clean. Prod. 2020, 259, 120905. [CrossRef]

224. Atabani, A.E.; Silitonga, A.S.; Ong, H.C.; Mahlia, T.M.I.; Masjuki, H.H.; Badruddin, I.A.; Fayaz, H. Non-edible vegetable oils: A critical evaluation of oil extraction, fatty acid compositions, biodiesel production, characteristics, engine performance and emissions production. Renew. Sustain. Energy Rev. 2013, 18, $211-245$. [CrossRef]

225. Hussain, A.I.; Anwar, F.; Hussain Sherazi, S.T.; Przybylski, R. Chemical composition, antioxidant and antimicrobial activities of basil (Ocimum basilicum) essential oils depends on seasonal variations. Food Chem. 2008, 108, 986-995. [CrossRef]

226. Goswami, D.; Basu, J.K.; De, S. Lipase applications in oil hydrolysis with a case study on castor oil: A review. Crit. Rev. Biotechnol. 2013, 33, 81-96. [CrossRef] [PubMed]

227. Shahinuzzaman, M.; Yaakob, Z.; Moniruzzaman, M. Medicinal and cosmetics soap production from Jatropha oil. J. Cosmet. Dermatol. 2016, 15, 185-193. [CrossRef] [PubMed]

228. Murty, V.R.; Bhat, J.; Muniswaran, P.K.A. Hydrolysis of oils by using immobilized lipase enzyme: A review. Biotechnol. Bioprocess Eng. 2002, 7, 57-66. [CrossRef]

229. Tan, T.; Lu, J.; Nie, K.; Deng, L.; Wang, F. Biodiesel production with immobilized lipase: A review. Biotechnol. Adv. 2010, 28, 628-634. [CrossRef] [PubMed]

230. Bajaj, A.; Lohan, P.; Jha, P.N.; Mehrotra, R. Biodiesel production through lipase catalyzed transesterification: An overview. J. Mol. Catal. B Enzym. 2010, 62, 9-14. [CrossRef]

231. Zhao, X.; Qi, F.; Yuan, C.; Du, W.; Liu, D. Lipase-catalyzed process for biodiesel production: Enzyme immobilization, process simulation and optimization. Renew. Sustain. Energy Rev. 2015, 44, 182-197. [CrossRef]

232. Aguieiras, E.C.G.; Cavalcanti-Oliveira, E.D.; Freire, D.M.G. Current status and new developments of biodiesel production using fungal lipases. Fuel 2015, 159, 52-67. [CrossRef]

233. Hama, S.; Noda, H.; Kondo, A. How lipase technology contributes to evolution of biodiesel production using multiple feedstocks. Curr. Opin. Biotechnol. 2018, 50, 57-64. [CrossRef]

234. Zhong, L.; Feng, Y.; Wang, G.; Wang, Z.; Bilal, M.; Lv, H.; Jia, S.; Cui, J. Production and use of immobilized lipases in/on nanomaterials: A review from the waste to biodiesel production. Int. J. Biol. Macromol. 2020, 152, 207-222. [CrossRef]

235. Wancura, J.H.C.; Tres, M.V.; Jahn, S.L.; Oliveira, J.V. Lipases in liquid formulation for biodiesel production: Current status and challenges. Biotechnol. Appl. Biochem. 2019. In press. [CrossRef]

236. Cammarota, M.C.; Freire, D.M.G. A review on hydrolytic enzymes in the treatment of wastewater with high oil and grease content. Bioresour. Technol. 2006, 97, 2195-2210. [CrossRef] [PubMed]

237. Rajendran, A.; Palanisamy, A.; Thangavelu, V. Lipase applications in food industry. Indian J. Biotechnol. 2007, $6,141-158$.

238. Satyarthi, J.K.; Srinivas, D.; Ratnasamy, P. Hydrolysis of vegetable oils and fats to fatty acids over solid acid catalysts. Appl. Catal. A Gen. 2011, 391, 427-435. [CrossRef]

239. Abdelmoez, W.; Mustafa, A. Oleochemical industry future through biotechnology. J. Oleo Sci. 2014, 63, 545-554. [CrossRef] [PubMed]

240. Abdelmoez, W.; Mostafa, N.A.; Mustafa, A. Utilization of oleochemical industry residues as substrates for lipase production for enzymatic sunflower oil hydrolysis. J. Clean. Prod. 2013, 59, 290-297. [CrossRef] 
241. Edwinoliver, N.G.; Thirunavukarasu, K.; Purushothaman, S.; Rose, C.; Gowthaman, M.K.; Kamini, N.R. Corn steep liquor as a nutrition adjunct for the production of Aspergillus niger lipase and hydrolysis of oils thereof. J. Agric. Food Chem. 2009, 57, 10658-10663. [CrossRef] [PubMed]

242. Alves, J.S.; Vieira, N.S.; Cunha, A.S.; Silva, A.M.; Záchia Ayub, M.A.; Fernandez-Lafuente, R.; Rodrigues, R.C. Combi-lipase for heterogeneous substrates: A new approach for hydrolysis of soybean oil using mixtures of biocatalysts. RSC Adv. 2014, 4, 6863-6868. [CrossRef]

243. Shimada, Y.; Watanabe, Y.; Sugihara, A.; Tominaga, Y. Enzymatic alcoholysis for biodiesel fuel production and application of the reaction to oil processing. J. Mol. Catal. B Enzym. 2002, 17, 133-142. [CrossRef]

244. Rodionova, M.V.; Poudyal, R.S.; Tiwari, I.; Voloshin, R.A.; Zharmukhamedov, S.K.; Nam, H.G.; Zayadan, B.K.; Bruce, B.D.; Hou, H.J.M.; Allakhverdiev, S.I. Biofuel production: Challenges and opportunities. Int. J. Hydrogen Energy 2017, 42, 8450-8461. [CrossRef]

245. Živković, S.B.; Veljković, M.V.; Banković-Ilić, I.B.; Krstić, I.M.; Konstantinović, S.S.; Ilić, S.B.; Avramović, J.M.; Stamenković, O.S.; Veljković, V.B. Technological, technical, economic, environmental, social, human health risk, toxicological and policy considerations of biodiesel production and use. Renew. Sustain. Energy Rev. 2017, 79, 222-247. [CrossRef]

246. Amini, Z.; Ilham, Z.; Ong, H.C.; Mazaheri, H.; Chen, W.-H. State of the art and prospective of lipase-catalyzed transesterification reaction for biodiesel production. Energy Convers. Manag. 2017, 141, 339-353. [CrossRef]

247. Poppe, J.K.; Fernandez-Lafuente, R.; Rodrigues, R.C.; Ayub, M.A.Z. Enzymatic reactors for biodiesel synthesis: Present status and future prospects. Biotechnol. Adv. 2015, 33, 511-525. [CrossRef] [PubMed]

248. Guldhe, A.; Singh, B.; Mutanda, T.; Permaul, K.; Bux, F. Advances in synthesis of biodiesel via enzyme catalysis: Novel and sustainable approaches. Renew. Sustain. Energy Rev. 2015, 41, 1447-1464. [CrossRef]

249. Ribeiro, B.D.; de Castro, A.M.; Coelho, M.A.Z.; Freire, D.M.G. Production and use of lipases in bioenergy: A review from the feedstocks to biodiesel production. Enzyme Res. 2011, 2011, 615803. [CrossRef] [PubMed]

250. Ortiz, C.; Ferreira, M.L.; Barbosa, O.; Dos Santos, J.C.S.; Rodrigues, R.C.; Berenguer-Murcia, Á.; Briand, L.E.; Fernandez-Lafuente, R. Novozym 435: The "perfect" lipase immobilized biocatalyst? Catal. Sci. Technol. 2019, 9, 2380-2420. [CrossRef]

251. Fernandez-Lafuente, R. Lipase from Thermomyces lanuginosus: Uses and prospects as an industrial biocatalyst. J. Mol. Catal. B Enzym. 2010, 62, 197-212. [CrossRef]

252. Rodrigues, R.C.; Fernandez-Lafuente, R. Lipase from Rhizomucor miehei as an industrial biocatalyst in chemical process. J. Mol. Catal. B Enzym. 2010, 64, 1-22. [CrossRef]

253. Rodrigues, R.C.; Fernandez-Lafuente, R. Lipase from Rhizomucor miehei as a biocatalyst in fats and oils modification. J. Mol. Catal. B Enzym. 2010, 66, 15-32. [CrossRef]

254. Rodrigues, R.C.; Volpato, G.; Wada, K.; Ayub, M.A.Z. Enzymatic Synthesis of biodiesel from transesterification reactions of vegetable oils and short chain alcohols. J. Am. Oil Chem. Soc. 2008, 85, 925-930. [CrossRef]

255. Ranganathan, S.V.; Narasimhan, S.L.; Muthukumar, K. An overview of enzymatic production of biodiesel. Bioresour. Technol. 2008, 99, 3975-3981. [CrossRef]

256. Szczęsna Antczak, M.; Kubiak, A.; Antczak, T.; Bielecki, S. Enzymatic biodiesel synthesis-Key factors affecting efficiency of the process. Renew. Energy 2009, 34, 1185-1194. [CrossRef]

257. Salis, A.; Pinna, M.; Monduzzi, M.; Solinas, V. Biodiesel production from triolein and short chain alcohols through biocatalysis. J. Biotechnol. 2005, 119, 291-299. [CrossRef] [PubMed]

258. Aguieiras, E.C.G.; Cavalcanti-Oliveira, E.D.; de Castro, A.M.; Langone, M.A.P.; Freire, D.M.G. Biodiesel production from Acrocomia aculeata acid oil by (enzyme/enzyme) hydroesterification process: Use of vegetable lipase and fermented solid as low-cost biocatalysts. Fuel 2014, 135, 315-321. [CrossRef]

259. de Sousa, J.S.; Cavalcanti-Oliveira, E.d.; Aranda, D.A.G.; Freire, D.M.G. Application of lipase from the physic nut (Jatropha curcas L.) to a new hybrid (enzyme/chemical) hydroesterification process for biodiesel production. J. Mol. Catal. B Enzym. 2010, 65, 133-137. [CrossRef]

260. Soares, D.; Pinto, A.F.; Gonçalves, A.G.; Mitchell, D.A.; Krieger, N. Biodiesel production from soybean soapstock acid oil by hydrolysis in subcritical water followed by lipase-catalyzed esterification using a fermented solid in a packed-bed reactor. Biochem. Eng. J. 2013, 81, 15-23. [CrossRef]

261. Bressani, A.P.P.; Garcia, K.C.A.; Hirata, D.B.; Mendes, A.A. Production of alkyl esters from macaw palm oil by a sequential hydrolysis/esterification process using heterogeneous biocatalysts: Optimization by response surface methodology. Bioprocess Biosyst. Eng. 2015, 38, 287-297. [CrossRef] 
262. Vescovi, V.; Rojas, M.J.; Baraldo, A.; Botta, D.C.; Santana, F.A.M.; Costa, J.P.; Machado, M.S.; Honda, V.K.; de Lima Camargo Giordano, R.; Tardioli, P.W. Lipase-catalyzed production of biodiesel by hydrolysis of waste cooking oil followed by esterification of free fatty acids. J. Am. Oil Chem. Soc. 2016, 93, 1615-1624. [CrossRef]

263. Zenevicz, M.C.P.; Jacques, A.; de Oliveira, D.; Furigo, A.; Valério, A.; Oliveira, J.V. A two-step enzymatic strategy to produce ethyl esters using frying oil as substrate. Ind. Crops Prod. 2017, 108, 52-55. [CrossRef]

264. Wancura, J.H.C.; Rosset, D.V.; Ugalde, G.A.; Oliveira, J.V.; Mazutti, M.A.; Tres, M.V.; Jahn, S.L. Feeding strategies of methanol and lipase on Eversa ${ }^{\circledR}$ Transform-mediated hydroesterification for FAME production. Can. J. Chem. Eng. 2019, 97, 1332-1339. [CrossRef]

265. Rosset, D.V.; Wancura, J.H.C.; Ugalde, G.A.; Oliveira, J.V.; Tres, M.V.; Kuhn, R.C.; Jahn, S.L. Enzyme-catalyzed production of FAME by hydroesterification of soybean oil using the novel soluble lipase ns 40116 . Appl. Biochem. Biotechnol. 2019, 188, 914-926. [CrossRef]

266. Wancura, J.H.C.; Rosset, D.V.; Mazutti, M.A.; Ugalde, G.A.; de Oliveira, J.V.; Tres, M.V.; Jahn, S.L. Improving the soluble lipase-catalyzed biodiesel production through a two-step hydroesterification reaction system. Appl. Microbiol. Biotechnol. 2019, 103, 7805-7817. [CrossRef] [PubMed]

267. Luque, R.; Clark, J.H. Biodiesel-like biofuels from simultaneous transesterification/esterification of waste oils with a biomass-derived solid acid catalyst. ChemCatChem 2011, 3, 594-597. [CrossRef]

268. Calero, J.; Luna, D.; Sancho, E.D.; Luna, C.; Bautista, F.M.; Romero, A.A.; Posadillo, A.; Berbel, J.; Verdugo-Escamilla, C. An overview on glycerol-free processes for the production of renewable liquid biofuels, applicable in diesel engines. Renew. Sustain. Energy Rev. 2015, 42, 1437-1452. [CrossRef]

269. Calero, J.; Verdugo, C.; Luna, D.; Sancho, E.D.; Luna, C.; Posadillo, A.; Bautista, F.M.; Romero, A.A. Selective ethanolysis of sunflower oil with Lipozyme RM IM, an immobilized Rhizomucor miehei lipase, to obtain a biodiesel-like biofuel, which avoids glycerol production through the monoglyceride formation. N. Biotechnol. 2014, 31, 596-601. [CrossRef]

270. Luna, C.; Verdugo, C.; Sancho, E.; Luna, D.; Calero, J.; Posadillo, A.; Bautista, F.; Romero, A. Biocatalytic behaviour of immobilized Rhizopus oryzae lipase in the 1,3-selective ethanolysis of sunflower oil to obtain a biofuel similar to biodiesel. Molecules 2014, 19, 11419-11439. [CrossRef]

271. Luna, C.; Verdugo, C.; Sancho, E.D.; Luna, D.; Calero, J.; Posadillo, A.; Bautista, F.M.; Romero, A.A. Production of a biodiesel-like biofuel without glycerol generation, by using Novozym 435, an immobilized Candida antarctica lipase. Bioresour. Bioprocess. 2014, 1, 11. [CrossRef]

272. Verdugo, C.; Luna, D.; Posadillo, A.; Sancho, E.D.; Rodríguez, S.; Bautista, F.; Luque, R.; Marinas, J.M.; Romero, A.A. Production of a new second generation biodiesel with a low cost lipase derived from Thermomyces lanuginosus: Optimization by response surface methodology. Catal. Today 2011, 167, 107-112. [CrossRef]

273. Poppe, J.K.; Matte, C.R.; do Peralba, M.C.R.; Fernandez-Lafuente, R.; Rodrigues, R.C.; Ayub, M.A.Z. Optimization of ethyl ester production from olive and palm oils using mixtures of immobilized lipases. Appl. Catal. A Gen. 2015, 490, 50-56. [CrossRef]

274. Brocca, S.; Schmidt-Dannert, C.; Schmid, R.D.; Lotti, M.; Alberghina, L. Design, total synthesis, and functional overexpression of the Candida rugosa lipl gene coding for a major industrial lipase. Protein Sci. 1998, 7 , 1415-1422. [CrossRef]

275. Brocca, S.; Secundo, F.; Ossola, M.; Alberghina, L.; Carrea, G.; Lotti, M. Sequence of the lid affects activity and specificity of Candida rugosa lipase isoenzymes. Protein Sci. 2003, 12, 2312-2319. [CrossRef]

276. Piamtongkam, R.; Duquesne, S.; Bordes, F.; Barbe, S.; André, I.; Marty, A.; Chulalaksananukul, W. Enantioselectivity of Candida rugosa lipases (Lip1, Lip3, and Lip4) towards 2-bromo phenylacetic acid octyl esters controlled by a single amino acid. Biotechnol. Bioeng. 2011, 108, 1749-1756. [CrossRef] [PubMed]

277. Bertolini, M.C.; Laramée, L.; Thomas, D.Y.; Cygler, M.; Schrag, J.D.; Vernet, T. Polymorphism in the lipase genes of Geotrichum candidum strains. Eur. J. Biochem. 1994, 219, 119-125. [CrossRef] [PubMed]

278. Bertolini, M.C.; Schrag, J.D.; Cygler, M.; Ziomek, E.; Thomas, D.Y.; Vernet, T. Expression and characterization of Geotrichum candidum lipase I gene: Comparison of specificity profile with lipase II. Eur. J. Biochem. 1995, 228, 863-869. [CrossRef] [PubMed]

279. van Kampen, M.D.; Rosenstein, R.; Götz, F.; Egmond, M.R. Cloning, purification and characterisation of Staphylococcus warneri lipase 2. Biochim. Biophys. Acta Protein Struct. Mol. Enzymol. 2001, 1544, $229-241$. [CrossRef] 
280. Cunha, A.G.; Fernández-Lorente, G.; Gutarra, M.L.E.; Bevilaqua, J.V.; Almeida, R.V.; Paiva, L.M.C.; Fernández-Lafuente, R.; Guisán, J.M.; Freire, D.M.G. Separation and immobilization of lipase from Penicillium simplicissimum by selective adsorption on hydrophobic supports. Appl. Biochem. Biotechnol. 2009, 156, 133-145. [CrossRef]

281. Chen, H.-P.; Hsiao, K.-F.; Wu, S.-H.; Wang, K.-T. Regioselectivity enhancement by partial purification of lipase from Aspergillus niger. Biotechnol. Lett. 1995, 17, 305-308. [CrossRef]

282. Mendes, A.A.; Oliveira, P.C.; de Castro, H.F. Properties and biotechnological applications of porcine pancreatic lipase. J. Mol. Catal. B Enzym. 2012, 78, 119-134. [CrossRef]

283. Ferreira, M.M.; de Oliveira, G.F.; Basso, R.C.; Mendes, A.A.; Hirata, D.B. Optimization of free fatty acid production by enzymatic hydrolysis of vegetable oils using a non-commercial lipase from Geotrichum candidum. Bioprocess Biosyst. Eng. 2019, 42, 1647-1659. [CrossRef]

284. Segura, R.L.; Palomo, J.M.; Mateo, C.; Cortes, A.; Terreni, M.; Fernández-Lafuente, R.; Guisan, J.M. Different properties of the lipases contained in porcine pancreatic lipase extracts as enantioselective biocatalysts. Biotechnol. Prog. 2004, 20, 825-829. [CrossRef]

285. Palomo, J.M.; Fernández-Lorente, G.; Mateo, C.; Fuentes, M.; Guisan, J.M.; Fernández-Lafuente, R. Enzymatic production of $(3 \mathrm{~S}, 4 \mathrm{R})-(-)-4-\left(4^{\prime}\right.$-fluorophenyl)-6-oxo-piperidin-3-carboxylic acid using a commercial preparation from Candida antarctica A: The role of a contaminant esterase. Tetrahedron: Asymmetry 2002, 13, 2653-2659. [CrossRef]

286. Segura, R.L.; Betancor, L.; Palomo, J.M.; Hidalgo, A.; Fernández-Lorente, G.; Terreni, M.; Mateo, C.; Cortés, A.; Fernández-Lafuente, R.; Guisán, J.M. Purification and identification of different lipases contained in PPL commercial extracts: A minor contaminant is the main responsible of most esterasic activity. Enzyme Microb. Technol. 2006, 39, 817-823. [CrossRef]

287. Arana-Peña, S.; Carballares, D.; Morellon-Sterling, S.; Berenguer-Murcia, A.; Alcantara, A.R.; Rodrigues, R.C.; Fernandez-Lafuente, R. Enzyme co-immobilization: Always the biocatalyst designers' choice ... or not? Biotechnol. Adv.. Accepted.

288. Buaban, B.; Inoue, H.; Yano, S.; Tanapongpipat, S.; Ruanglek, V.; Champreda, V.; Pichyangkura, R.; Rengpipat, S.; Eurwilaichitr, L. Bioethanol production from ball milled bagasse using an on-site produced fungal enzyme cocktail and xylose-fermenting Pichia stipitis. J. Biosci. Bioeng. 2010, 110, 18-25. [CrossRef]

289. Passos, C.P.; Yilmaz, S.; Silva, C.M.; Coimbra, M.A. Enhancement of grape seed oil extraction using a cell wall degrading enzyme cocktail. Food Chem. 2009, 115, 48-53. [CrossRef]

290. Sørensen, H.R.; Pedersen, S.; Jørgensen, C.T.; Meyer, A.S. Enzymatic hydrolysis of wheat arabinoxylan by a recombinant "minimal" enzyme cocktail containing $\beta$-xylosidase and novel endo- $1,4-\beta$-xylanase and $\alpha$-l-arabinofuranosidase activities. Biotechnol. Prog. 2007, 23, 100-107. [CrossRef] [PubMed]

291. Verma, D.; Kanagaraj, A.; Jin, S.; Singh, N.D.; Kolattukudy, P.E.; Daniell, H. Chloroplast-derived enzyme cocktails hydrolyse lignocellulosic biomass and release fermentable sugars. Plant Biotechnol. J. 2010, 8, 332-350. [CrossRef]

292. Yamada, R.; Taniguchi, N.; Tanaka, T.; Ogino, C.; Fukuda, H.; Kondo, A. Cocktail $\delta$-integration: A novel method to construct cellulolytic enzyme expression ratio-optimized yeast strains. Microb. Cell Fact. 2010, 9, 32. [CrossRef]

293. Brabcová, J.; Demianová, Z.; Vondrášek, J.; Jágr, M.; Zarevúcka, M.; Palomo, J.M. Highly selective purification of three lipases from Geotrichum candidum 4013 and their characterization and biotechnological applications. J. Mol. Catal. B Enzym. 2013, 98, 62-72. [CrossRef]

294. Fernández-Lorente, G.; Ortiz, C.; Segura, R.L.; Fernández-Lafuente, R.; Guisán, J.M.; Palomo, J.M. Purification of different lipases from Aspergillus niger by using a highly selective adsorption on hydrophobic supports. Biotechnol. Bioeng. 2005, 92, 773-779. [CrossRef]

295. Volpato, G.; Filice, M.; Ayub, M.A.Z.; Guisan, J.M.; Palomo, J.M. Single-step purification of different lipases from Staphylococcus warneri. J. Chromatogr. A 2010, 1217, 473-478. [CrossRef]

296. Hirata, D.; Fernández-Lafuente, R.; Basso1, R.; Mendes, A.; Tavano, O.; Badino, A.; Oliveira, L.; Esperança, M.; Moreira, N.; Castro, P. High lipase production from Geotrichum candidum in reduced time using cottonseed oil: Optimization, easy purification and specificity characterization. J. Chem. Eng. Res. Updat. 2017, 3, 60-69. [CrossRef] 
297. Guldhe, A.; Singh, P.; Ansari, F.A.; Singh, B.; Bux, F. Biodiesel synthesis from microalgal lipids using tungstated zirconia as a heterogeneous acid catalyst and its comparison with homogeneous acid and enzyme catalysts. Fuel 2017, 187, 180-188. [CrossRef]

298. Ren, H.; Du, W.; Lv, L.; Liu, D. Study on free lipase-catalyzed ethanolysis for biodiesel preparation in an oil/water biphasic system. J. Am. Oil Chem. Soc. 2011, 88, 1551-1555. [CrossRef]

299. Zhao, X.; El-Zahab, B.; Brosnahan, R.; Perry, J.; Wang, P. An organic soluble lipase for water-free synthesis of biodiesel. Appl. Biochem. Biotechnol. 2007, 143, 236-243. [CrossRef]

300. Firdaus, M.Y.; Brask, J.; Nielsen, P.M.; Guo, Z.; Fedosov, S. Kinetic model of biodiesel production catalyzed by free liquid lipase from Thermomyces lanuginosus. J. Mol. Catal. B Enzym. 2016, 133, 55-64. [CrossRef]

301. Cesarini, S.; Diaz, P.; Nielsen, P.M. Exploring a new, soluble lipase for FAMEs production in water-containing systems using crude soybean oil as a feedstock. Process Biochem. 2013, 48, 484-487. [CrossRef]

302. Chen, X.; Du, W.; Liu, D. Effect of several factors on soluble lipase-mediated biodiesel preparation in the biphasic aqueous-oil systems. World J. Microbiol. Biotechnol. 2008, 24, 2097-2102. [CrossRef]

303. Wancura, J.H.C.; Rosset, D.V.; Brondani, M.; Mazutti, M.A.; Oliveira, J.V.; Tres, M.V.; Jahn, S.L. Soluble lipase-catalyzed synthesis of methyl esters using a blend of edible and nonedible raw materials. Bioprocess Biosyst. Eng. 2018, 41, 1185-1193. [CrossRef]

304. Cesarini, S.; Pastor, F.I.J.; Diaz, P. Improvement of P. aeruginosa 42A2 lipase preparations for FAMEs production, both in immobilized and soluble form. J. Mol. Catal. B Enzym. 2014, 99, 1-7. [CrossRef]

305. Lam, M.K.; Lee, K.T.; Mohamed, A.R. Homogeneous, heterogeneous and enzymatic catalysis for transesterification of high free fatty acid oil (waste cooking oil) to biodiesel: A review. Biotechnol. Adv. 2010, 28, 500-518. [CrossRef]

306. Remonatto, D.; Santin, C.M.T.; de Oliveira, D.; Di Luccio, M.; de Oliveira, J.V. FAME Production from waste oils through commercial soluble lipase Eversa ${ }^{\circledR}$ catalysis. Ind. Biotechnol. 2016, 12, 254-262. [CrossRef]

307. Adewale, P.; Vithanage, L.N.; Christopher, L. Optimization of enzyme-catalyzed biodiesel production from crude tall oil using Taguchi method. Energy Convers. Manag. 2017, 154, 81-91. [CrossRef]

308. Andrade, T.A.; Errico, M.; Christensen, K.V. Evaluation of reaction mechanisms and kinetic parameters for the transesterification of castor oil by liquid enzymes. Ind. Eng. Chem. Res. 2017, 56, 9478-9488. [CrossRef]

309. Séverac, E.; Galy, O.; Turon, F.; Pantel, C.A.; Condoret, J.-S.; Monsan, P.; Marty, A. Selection of CalB immobilization method to be used in continuous oil transesterification: Analysis of the economical impact. Enzyme Microb. Technol. 2011, 48, 61-70. [CrossRef] [PubMed]

310. Dossat, V.; Combes, D.; Marty, A. Continuous enzymatic transesterification of high oleic sunflower oil in a packed bed reactor: Influence of the glycerol production. Enzyme Microb. Technol. 1999, 25, 194-200. [CrossRef]

311. Marty, A.; Dossat, V.; Condoret, J.-S. Continuous operation of lipase-catalyzed reactions in nonaqueous solvents: Influence of the production of hydrophilic compounds. Biotechnol. Bioeng. 1997, 56, 232-237. [CrossRef]

312. Castillo, E.; Dossat, V.; Marty, A.; Condoret, J.S.; Combes, D. The role of silica gel in lipase-catalyzed esterification reactions of high-polar substrates. J. Am. Oil Chem. Soc. 1997, 74, 77-85. [CrossRef]

313. Martins, A.B.; Friedrich, J.L.R.; Cavalheiro, J.C.; Garcia-Galan, C.; Barbosa, O.; Ayub, M.A.Z.; Fernandez-Lafuente, R.; Rodrigues, R.C. Improved production of butyl butyrate with lipase from Thermomyces lanuginosus immobilized on styrene-divinylbenzene beads. Bioresour. Technol. 2013, 134, 417-422. [CrossRef]

314. Graebin, N.G.; Martins, A.B.; Lorenzoni, A.S.G.; Garcia-Galan, C.; Fernandez-Lafuente, R.; Ayub, M.A.Z.; Rodrigues, R.C. Immobilization of lipase B from Candida antarctica on porous styrene-divinylbenzene beads improves butyl acetate synthesis. Biotechnol. Prog. 2012, 28, 406-412. [CrossRef]

315. Poppe, J.K.; Garcia-Galan, C.; Matte, C.R.; Fernandez-Lafuente, R.; Rodrigues, R.C.; Ayub, M.A.Z. Optimization of synthesis of fatty acid methyl esters catalyzed by lipase B from Candida antarctica immobilized on hydrophobic supports. J. Mol. Catal. B Enzym. 2013, 94, 51-56. [CrossRef]

316. Martins, A.B.; Schein, M.F.; Friedrich, J.L.R.; Fernandez-Lafuente, R.; Ayub, M.A.Z.; Rodrigues, R.C. Ultrasound-assisted butyl acetate synthesis catalyzed by Novozym 435: Enhanced activity and operational stability. Ultrason. Sonochem. 2013, 20, 1155-1160. [CrossRef] [PubMed]

317. Paludo, N.; Alves, J.S.; Altmann, C.; Ayub, M.A.Z.; Fernandez-Lafuente, R.; Rodrigues, R.C. The combined use of ultrasound and molecular sieves improves the synthesis of ethyl butyrate catalyzed by immobilized Thermomyces lanuginosus lipase. Ultrason. Sonochem. 2015, 22, 89-94. [CrossRef] [PubMed] 
318. Fallavena, L.P.; Antunes, F.H.F.; Alves, J.S.; Paludo, N.; Ayub, M.A.Z.; Fernandez-Lafuente, R.; Rodrigues, R.C. Ultrasound technology and molecular sieves improve the thermodynamically controlled esterification of butyric acid mediated by immobilized lipase from Rhizomucor miehei. RSC Adv. 2014, 4, 8675-8681. [CrossRef]

319. Akita, H.; Umezawa, I.; Sakurai, I.; Oishi, T. Structural characteristics of lipid-lipase aggregates for enantioselective hydrolysis in organic solvents. Chem. Pharm. Bull. 1993, 41, 12-15. [CrossRef]

320. Shimizu, N.; Akita, H.; Kawamata, T. Enantioselective reaction of (.+-.)-1-Hydroxy-5-methyl-3-vinylcyclohex-2-ene and its acyl derivatives using lipid-lipase aggregates in organic solvent. Chem. Pharm. Bull. 1996, 44, 665-669. [CrossRef]

321. Dordick, J.S. Enzymatic catalysis in monophasic organic solvents. Enzyme Microb. Technol. 1989, 11, $194-211$. [CrossRef]

322. Klibanov, A.M. Enzymatic catalysis in anhydrous organic solvents. Trends Biochem. Sci. 1989, 14, 141-144. [CrossRef]

323. Virgen-Ortíz, J.J.; Tacias-Pascacio, V.G.; Hirata, D.B.; Torrestiana-Sanchez, B.; Rosales-Quintero, A.; Fernandez-Lafuente, R. Relevance of substrates and products on the desorption of lipases physically adsorbed on hydrophobic supports. Enzyme Microb. Technol. 2017, 96, 30-35. [CrossRef]

324. Virgen-Ortíz, J.J.; Peirce, S.; Tacias-Pascacio, V.G.; Cortes-Corberan, V.; Marzocchella, A.; Russo, M.E.; Fernandez-Lafuente, R. Reuse of anion exchangers as supports for enzyme immobilization: Reinforcement of the enzyme-support multiinteraction after enzyme inactivation. Process Biochem. 2016, 51, 1391-1396. [CrossRef]

325. Virgen-Ortíz, J.J.; Pedrero, S.G.; Fernandez-Lopez, L.; Lopez-Carrobles, N.; Gorines, B.C.; Otero, C.; Fernandez-Lafuente, R. Desorption of lipases immobilized on octyl-agarose beads and coated with ionic polymers after thermal inactivation. Stronger adsorption of polymers/unfolded protein composites. Molecules 2017, 22, 91. [CrossRef]

326. Virgen-Ortíz, J.J.; dos Santos, J.C.S.; Berenguer-Murcia, Á.; Barbosa, O.; Rodrigues, R.C.; Fernandez-Lafuente, R. Polyethylenimine: A very useful ionic polymer in the design of immobilized enzyme biocatalysts. J. Mater. Chem. B 2017, 5, 7461-7490. [CrossRef] [PubMed]

327. Tacias-Pascacio, V.G.; Ortiz, C.; Rueda, N.; Berenguer-Murcia, Á.; Acosta, N.; Aranaz, I.; Civera, C.; Fernandez-Lafuente, R.; Alcántara, A.R. Dextran aldehyde in biocatalysis: More than a mere immobilization system. Catalysts 2019, 9, 622. [CrossRef]

328. Palomo, J.M.; Fuentes, M.; Fernández-Lorente, G.; Mateo, C.; Guisan, J.M.; Fernández-Lafuente, R. General trend of lipase to self-assemble giving bimolecular aggregates greatly modifies the enzyme functionality. Biomacromolecules 2003, 4, 1-6. [CrossRef] [PubMed]

329. Fernández-Lorente, G.; Palomo, J.M.; Fuentes, M.; Mateo, C.; Guisán, J.M.; Fernández-Lafuente, R. Self-assembly of Pseudomonas fluorescens lipase into bimolecular aggregates dramatically affects functional properties. Biotechnol. Bioeng. 2003, 82, 232-237. [CrossRef]

330. Palomo, J.M.; Ortiz, C.; Fuentes, M.; Fernandez-Lorente, G.; Guisan, J.M.; Fernandez-Lafuente, R. Use of immobilized lipases for lipase purification via specific lipase-lipase interactions. J. Chromatogr. A 2004, 1038, 267-273. [CrossRef]

331. Palomo, J.M.; Ortiz, C.; Fernández-Lorente, G.; Fuentes, M.; Guisán, J.M.; Fernández-Lafuente, R. Lipase-lipase interactions as a new tool to immobilize and modulate the lipase properties. Enzyme Microb. Technol. 2005, 36, 447-454. [CrossRef]

332. Palomo, J.M.; Peñas, M.M.; Fernández-Lorente, G.; Mateo, C.; Pisabarro, A.G.; Fernández-Lafuente, R.; Ramírez, L.; Guisán, J.M. Solid-phase handling of hydrophobins: Immobilized hydrophobins as a new tool to study lipases. Biomacromolecules 2003, 4, 204-210. [CrossRef]

333. Park, Y.K.; Pastore, G.M.; de Almeida, M.M. Hydrolysis of soybean oil by a combined lipase system. J. Am. Oil Chem. Soc. 1988, 65, 252-254. [CrossRef]

334. Qiao, H.; Zhang, F.; Guan, W.; Zuo, J.; Feng, D. Optimisation of combi-lipases from Aspergillus niger for the synergistic and efficient hydrolysis of soybean oil. Anim. Sci. J. 2017, 88, 772-780. [CrossRef]

335. Huang, J.; Zhao, Q.; Bu, W.; Zhang, C.; Yang, Z.; Zhang, X.; Zhang, K. Ultrasound-assisted hydrolysis of lard for free fatty acids catalyzed by combined two lipases in aqueous medium. Bioengineered 2020, 11, 241-250. [CrossRef] 
336. Guan, F.; Peng, P.; Wang, G.; Yin, T.; Peng, Q.; Huang, J.; Guan, G.; Li, Y. Combination of two lipases more efficiently catalyzes methanolysis of soybean oil for biodiesel production in aqueous medium. Process Biochem. 2010, 45, 1677-1682. [CrossRef]

337. Karmee, S.K. Preparation of biodiesel from nonedible oils using a mixture of used lipases. Energy Sources, Part A Recover. Util. Environ. Eff. 2016, 38, 2727-2733. [CrossRef]

338. Zeng, L.; He, Y.; Jiao, L.; Li, K.; Yan, Y. Preparation of biodiesel with liquid synergetic lipases from rapeseed oil deodorizer distillate. Appl. Biochem. Biotechnol. 2017, 183, 778-791. [CrossRef] [PubMed]

339. Amoah, J.; Ho, S.H.; Hama, S.; Yoshida, A.; Nakanishi, A.; Hasunuma, T.; Ogino, C.; Kondo, A. Conversion of Chlamydomonas sp. JSC4 lipids to biodiesel using Fusarium heterosporum lipase-expressing Aspergillus oryzae whole-cell as biocatalyst. Algal Res. 2017, 28, 16-23. [CrossRef]

340. Jang, M.G.; Kim, D.K.; Park, S.C.; Lee, J.S.; Kim, S.W. Biodiesel production from crude canola oil by two-step enzymatic processes. Renew. Energy 2012, 42, 99-104. [CrossRef]

341. Cesarini, S.; Haller, R.; Diaz, P.; Nielsen, P. Combining phospholipases and a liquid lipase for one-step biodiesel production using crude oils. Biotechnol. Biofuels 2014, 7, 29. [CrossRef]

342. Amoah, J.; Ho, S.-H.; Hama, S.; Yoshida, A.; Nakanishi, A.; Hasunuma, T.; Ogino, C.; Kondo, A. Lipase cocktail for efficient conversion of oils containing phospholipids to biodiesel. Bioresour. Technol. 2016, 211, 224-230. [CrossRef]

343. Hirose, T.; Yamauchi-Sato, Y.; Arai, Y.; Negishi, S. Synthesis of triacylglycerol containing conjugated linoleic acid by esterification using two blended lipases. J. Am. Oil Chem. Soc. 2006, 83, 35-38. [CrossRef]

344. McNeill, G.P.; Yamane, T. Further improvements in the yield of monoglycerides during enzymatic glycerolysis of fats and oils. J. Am. Oil Chem. Soc. 1991, 68, 6-10. [CrossRef]

345. Speranza, P.; Ribeiro, A.P.B.; Macedo, G.A. Lipase catalyzed interesterification of Amazonian patauá oil and palm stearin for preparation of specific-structured oils. J. Food Sci. Technol. 2015, 52, 8268-8275. [CrossRef]

346. Macrae, A.R. Lipase-catalyzed interesterification of oils and fats. J. Am. Oil Chem. Soc. 1983, 60, $291-294$. [CrossRef]

347. Soumanou, M.M.; Pérignon, M.; Villeneuve, P. Lipase-catalyzed interesterification reactions for human milk fat substitutes production: A review. Eur. J. Lipid Sci. Technol. 2013, 115, 270-285. [CrossRef]

348. Utama, Q.D.; Sitanggang, A.B.; Adawiyah, D.R.; Hariyadi, P. Lipase-catalyzed interesterification for the synthesis of medium-long-medium (MLM) structured lipids. Food Technol. Biotechnol. 2019, 57, 305-318. [CrossRef]

349. Speranza, P.; Ribeiro, A.P.B.; Macedo, G.A. Application of lipases to regiospecific interesterification of exotic oils from an Amazonian area. J. Biotechnol. 2016, 218, 13-20. [CrossRef]

350. Di Cosimo, R.; Mc Auliffe, J.; Poulose, A.J.; Bohlmann, G. Industrial use of immobilized enzymes. Chem. Soc. Rev. 2013, 42, 6437-6474. [CrossRef]

351. Liese, A.; Hilterhaus, L. Evaluation of immobilized enzymes for industrial applications. Chem. Soc. Rev. 2013, 42, 6236-6249. [CrossRef]

352. Iyer, P.V.; Ananthanarayan, L. Enzyme stability and stabilization-aqueous and non-aqueous environment. Process Biochem. 2008, 43, 1019-1032. [CrossRef]

353. Mohamad, N.R.; Marzuki, N.H.C.; Buang, N.A.; Huyop, F.; Wahab, R.A. An overview of technologies for immobilization of enzymes and surface analysis techniques for immobilized enzymes. Biotechnol. Biotechnol. Equip. 2015, 29, 205-220. [CrossRef]

354. Barbosa, O.; Ortiz, C.; Berenguer-Murcia, Á.; Torres, R.; Rodrigues, R.C.; Fernandez-Lafuente, R. Strategies for the one-step immobilization-purification of enzymes as industrial biocatalysts. Biotechnol. Adv. 2015, 33, 435-456. [CrossRef]

355. Santos, J.C.S.D.; Barbosa, O.; Ortiz, C.; Berenguer-Murcia, A.; Rodrigues, R.C.; Fernandez-Lafuente, R. Importance of the support properties for immobilization or purification of enzymes. ChemCatChem 2015, 7, 2413-2432. [CrossRef]

356. Guzik, U.; Hupert-Kocurek, K.; Wojcieszyńska, D. Immobilization as a strategy for improving enzyme properties- Application to oxidoreductases. Molecules 2014, 19, 8995-9018. [CrossRef] [PubMed]

357. Fan, M.; Li, Q.; Zhao, X.; Du, W.; Liu, C.-M.; Liu, D.-H. Recovery of free lipase in the aqueous phase of enzymatic production of biodiesel by foam separation. Guocheng Gongcheng Xuebao/Chin. J. Process Eng. 2010, 10, 1187-1192. 
358. Gonçalves, M.C.P.; Kieckbusch, T.G.; Perna, R.F.; Fujimoto, J.T.; Morales, S.A.V.; Romanelli, J.P. Trends on enzyme immobilization researches based on bibliometric analysis. Process Biochem. 2019, 76, 95-110. [CrossRef]

359. Barbosa, O.; Torres, R.; Ortiz, C.; Berenguer-Murcia, A.; Rodrigues, R.C.; Fernandez-Lafuente, R. Heterofunctional supports in enzyme immobilization: From traditional immobilization protocols to opportunities in tuning enzyme properties. Biomacromolecules 2013, 14, 2433-2462. [CrossRef]

360. Manoel, E.A.; dos Santos, J.C.S.; Freire, D.M.G.; Rueda, N.; Fernandez-Lafuente, R. Immobilization of lipases on hydrophobic supports involves the open form of the enzyme. Enzyme Microb. Technol. 2015, 71, 53-57. [CrossRef]

361. Kim, K.K.; Song, H.K.; Shin, D.H.; Hwang, K.Y.; Suh, S.W. The crystal structure of a triacylglycerol lipase from Pseudomonas cepacia reveals a highly open conformation in the absence of a bound inhibitor. Structure 1997, 5, 173-185. [CrossRef]

362. Jaeger, K.-E.; Ransac, S.; Koch, H.B.; Ferrato, F.; Dijkstra, B.W. Topological characterization and modeling of the 3D structure of lipase from Pseudomonas aeruginosa. FEBS Lett. 1993, 332, 143-149. [CrossRef]

363. Cygler, M.; Schrag, J.D. Structure and conformational flexibility of Candida rugosa lipase 11NRC. Biochim. Biophys. Acta Mol. Cell Biol. Lipids 1999, 1441, 205-214. [CrossRef]

364. Dos Santos, J.C.S.; Rueda, N.; Torres, R.; Barbosa, O.; Gonçalves, L.R.B.; Fernandez-Lafuente, R. Evaluation of divinylsulfone activated agarose to immobilize lipases and to tune their catalytic properties. Process Biochem. 2015, 50, 918-927. [CrossRef]

365. Dos Santos, J.C.S.; Rueda, N.; Sanchez, A.; Villalonga, R.; Gonçalves, L.R.B.; Fernandez-Lafuente, R. Versatility of divinylsulfone supports permits the tuning of CALB properties during its immobilization. RSC Adv. 2015, 5, 35801-35810. [CrossRef]

366. Arana-Peña, S.; Rios, N.S.; Carballares, D.; Mendez-Sanchez, C.; Lokha, Y.; Gonçalves, L.R.B.; Fernandez-Lafuente, R. Effects of enzyme loading and immobilization conditions on the catalytic features of lipase from Pseudomonas fluorescens immobilized on octyl-agarose beads. Front. Bioeng. Biotechnol. 2020, 8, 36. [CrossRef] [PubMed]

367. Lokha, Y.; Arana-Peña, S.; Rios, N.S.; Mendez-Sanchez, C.; Gonçalves, L.R.B.; Lopez-Gallego, F.; Fernandez-Lafuente, R. Modulating the properties of the lipase from Thermomyces lanuginosus immobilized on octyl agarose beads by altering the immobilization conditions. Enzyme Microb. Technol. 2020, 133, 109461. [CrossRef] [PubMed]

368. Arana-Peña, S.; Rios, N.S.; Carballares, D.; Gonçalves, L.R.B.; Fernandez-Lafuente, R. Immobilization of lipases via interfacial activation on hydrophobic supports: Production of biocatalysts libraries by altering the immobilization conditions. Catal. Today 2020. In press. [CrossRef]

369. Rueda, N.; dos Santos, J.C.S.; Torres, R.; Ortiz, C.; Barbosa, O.; Fernandez-Lafuente, R. Improved performance of lipases immobilized on heterofunctional octyl-glyoxyl agarose beads. RSC Adv. 2015, 5, 11212-11222. [CrossRef]

370. Albuquerque, T.L.D.; Rueda, N.; Dos Santos, J.C.S.; Barbosa, O.; Ortiz, C.; Binay, B.; Özdemir, E.; Gonçalves, L.R.B.; Fernandez-Lafuente, R. Easy stabilization of interfacially activated lipases using heterofunctional divinyl sulfone activated-octyl agarose beads. Modulation of the immobilized enzymes by altering their nanoenvironment. Process Biochem. 2016, 51, 865-874. [CrossRef]

371. Suescun, A.; Rueda, N.; dos Santos, J.C.S.; Castillo, J.J.; Ortiz, C.; Torres, R.; Barbosa, O.; Fernandez-Lafuente, R. Immobilization of lipases on glyoxyl-octyl supports: Improved stability and reactivation strategies. Process Biochem. 2015, 50, 1211-1217. [CrossRef]

372. Rueda, N.; Dos Santos, C.S.; Rodriguez, M.D.; Albuquerque, T.L.; Barbosa, O.; Torres, R.; Ortiz, C.; Fernandez-Lafuente, R. Reversible immobilization of lipases on octyl-glutamic agarose beads: A mixed adsorption that reinforces enzyme immobilization. J. Mol. Catal. B Enzym. 2016, 128, 10-18. [CrossRef]

373. Rueda, N.; dos Santos, J.C.S.; Ortiz, C.; Barbosa, O.; Fernandez-Lafuente, R.; Torres, R. Chemical amination of lipases improves their immobilization on octyl-glyoxyl agarose beads. Catal. Today 2016, 259, 107-118. [CrossRef]

374. Rueda, N.; Albuquerque, T.; Bartolome-Cabrero, R.; Fernandez-Lopez, L.; Torres, R.; Ortiz, C.; dos Santos, J.; Barbosa, O.; Fernandez-Lafuente, R. Reversible immobilization of lipases on heterofunctional octyl-amino agarose beads prevents enzyme desorption. Molecules 2016, 21, 646. [CrossRef] 
375. Fernandez-Lopez, L.; Rueda, N.; Bartolome-Cabrero, R.; Rodriguez, M.D.; Albuquerque, T.L.; Dos Santos, J.C.S.; Barbosa, O.; Fernandez-Lafuente, R. Improved immobilization and stabilization of lipase from Rhizomucor miehei on octyl-glyoxyl agarose beads by using $\mathrm{CaCl}_{2}$. Process Biochem. 2016, 51, 48-52. [CrossRef]

376. Rueda, N.; Dos Santos, J.C.S.; Torres, R.; Barbosa, O.; Ortiz, C.; Fernandez-Lafuente, R. Reactivation of lipases by the unfolding and refolding of covalently immobilized biocatalysts. RSC Adv. 2015, 5, 55588-55594. [CrossRef]

377. Rios, N.S.; Mendez-Sanchez, C.; Arana-Peña, S.; Rueda, N.; Ortiz, C.; Gonçalves, L.R.B.; Fernandez-Lafuente, R. Immobilization of lipase from Pseudomonas fluorescens on glyoxyl-octyl-agarose beads: Improved stability and reusability. Biochim. Biophys. Acta Proteins Proteom. 2019, 1867, 741-747. [CrossRef] [PubMed]

378. Fernandez-Lopez, L.; Pedrero, S.G.; Lopez-Carrobles, N.; Virgen-Ortíz, J.J.; Gorines, B.C.; Otero, C.; Fernandez-Lafuente, R. Physical crosslinking of lipase from Rhizomucor miehei immobilized on octyl agarose via coating with ionic polymers. Process Biochem. 2017, 54, 81-88. [CrossRef]

379. Zaak, H.; Fernandez-Lopez, L.; Otero, C.; Sassi, M.; Fernandez-Lafuente, R. Improved stability of immobilized lipases via modification with polyethylenimine and glutaraldehyde. Enzyme Microb. Technol. 2017, 106, 67-74. [CrossRef]

380. Fernandez-Lopez, L.; Virgen-OrtÍz, J.J.; Pedrero, S.G.; Lopez-Carrobles, N.; Gorines, B.C.; Otero, C.; Fernandez-Lafuente, R. Optimization of the coating of octyl-CALB with ionic polymers to improve stability and decrease enzyme leakage. Biocatal. Biotransform. 2018, 36, 47-56. [CrossRef]

381. Lee, J.H.; Lee, D.H.; Lim, J.S.; Um, B.H.; Park, C.; Kang, S.W.; Kim, S.W. Optimization of the process for biodiesel production using a mixture of immobilized Rhizopus oryzae and Candida rugosa lipases. J. Microbiol. Biotechnol. 2008, 18, 1927-1931.

382. Lee, J.H.; Kim, S.B.; Park, C.; Tae, B.; Han, S.O.; Kim, S.W. Development of batch and continuous processes on biodiesel production in a packed-bed reactor by a mixture of immobilized Candida rugosa and Rhizopus oryzae lipases. Appl. Biochem. Biotechnol. 2010, 161, 365-371. [CrossRef]

383. Lee, J.H.; Kim, S.B.; Kang, S.W.; Song, Y.S.; Park, C.; Han, S.O.; Kim, S.W. Biodiesel production by a mixture of Candida rugosa and Rhizopus oryzae lipases using a supercritical carbon dioxide process. Bioresour. Technol. 2011, 102, 2105-2108. [CrossRef]

384. Li, Q.; Zheng, J.; Yan, Y. Biodiesel preparation catalyzed by compound-lipase in co-solvent. Fuel Process. Technol. 2010, 91, 1229-1234. [CrossRef]

385. Huang, Y.; Zheng, H.; Yan, Y. Optimization of lipase-catalyzed transesterification of lard for biodiesel production using response surface methodology. Appl. Biochem. Biotechnol. 2010, 160, 504-515. [CrossRef]

386. Liu, Y.; Yan, Y.; Hu, F.; Yao, A.; Wang, Z.; Wei, F. Transesterification for biodiesel production catalyzed by combined lipases: Optimization and kinetics. AIChE J. 2010, 56, 1659-1665. [CrossRef]

387. Liu, Y.; Wu, H.; Yan, Y.; Dong, L.; Zhu, M.; Liang, P. Lipase-catalyzed transesterification for biodiesel production in ionic liquid [Emim]Tfo. Int. J. Green Energy 2013, 10, 63-71. [CrossRef]

388. Tongboriboon, K.; Cheirsilp, B.; H-Kittikun, A. Mixed lipases for efficient enzymatic synthesis of biodiesel from used palm oil and ethanol in a solvent-free system. J. Mol. Catal. B Enzym. 2010, 67, 52-59. [CrossRef]

389. Banerjee, A.; Singh, V.; Solanki, K.; Mukherjee, J.; Gupta, M. Combi-protein coated microcrystals of lipases for production of biodiesel from oil from spent coffee grounds. Sustain. Chem. Process. 2013, 1, 14. [CrossRef]

390. Babaki, M.; Yousefi, M.; Habibi, Z.; Mohammadi, M. Process optimization for biodiesel production from waste cooking oil using multi-enzyme systems through response surface methodology. Renew. Energy 2017, 105, 465-472. [CrossRef]

391. Poppe, J.K.; Matte, C.R.; de Freitas, V.O.; Fernandez-Lafuente, R.; Rodrigues, R.C.; Záchia Ayub, M.A. Enzymatic synthesis of ethyl esters from waste oil using mixtures of lipases in a plug-flow packed-bed continuous reactor. Biotechnol. Prog. 2018, 34, 952-959. [CrossRef]

392. Araki, C.A.; Marcucci, S.M.P.; da Silva, L.S.; Maeda, C.H.; Arroyo, P.A.; Zanin, G.M. Effects of a combination of lipases immobilised on desilicated and thiol-modified ZSM-5 for the synthesis of ethyl esters from macauba pulp oil in a solvent-free system. Appl. Catal. A Gen. 2018, 562, 241-249. [CrossRef]

393. Poppe, J.K.; Matte, C.R.; Fernandez-Lafuente, R.; Rodrigues, R.C.; Ayub, M.A.Z. Transesterification of waste frying oil and soybean oil by combi-lipases under ultrasound-assisted reactions. Appl. Biochem. Biotechnol. 2018, 186, 576-589. [CrossRef] 
394. de Freitas, V.O.; Matte, C.R.; Poppe, J.K.; Rodrigues, R.C.; Ayub, M.A.Z. Ultrasound-assisted transesterification of soybean oil using combi-lipase biocatalysts. Braz. J. Chem. Eng. 2019, 36, 995-1005. [CrossRef]

395. Sánchez-Bayo, A.; Morales, V.; Rodríguez, R.; Vicente, G.; Bautista, L. Biodiesel production (FAEEs) by heterogeneous combi-lipase biocatalysts using wet extracted lipids from microalgae. Catalysts 2019, 9, 296. [CrossRef]

396. Ramos, M.D.; Miranda, L.P.; Fernandez-Lafuente, R.; Kopp, W.; Tardioli, P.W. Improving the yields and reaction rate in the ethanolysis of soybean oil by using mixtures of lipase CLEAs. Molecules 2019, 24, 4392. [CrossRef] [PubMed]

397. Schoevaart, R.; Wolbers, M.W.; Golubovic, M.; Ottens, M.; Kieboom, A.P.G.; van Rantwijk, F.; van der Wielen, L.A.M.; Sheldon, R.A. Preparation, optimization, and structures of cross-linked enzyme aggregates (CLEAs). Biotechnol. Bioeng. 2004, 87, 754-762. [CrossRef] [PubMed]

398. Cao, L.; Van Rantwijk, F.; Sheldon, R.A. Cross-linked enzyme aggregates: A simple and effective method for the immobilization of penicillin acylase. Org. Lett. 2000, 2, 1361-1364. [CrossRef]

399. Chmura, A.; Rustler, S.; Paravidino, M.; Van Rantwijk, F.; Stolz, A.; Sheldon, R.A. The combi-CLEA approach: Enzymatic cascade synthesis of enantiomerically pure (S)-mandelic acid. Tetrahedron Asymmetry 2013, 24, 1225-1232. [CrossRef]

400. Chung, C.-F.; Lin, S.-C.; Juang, T.-Y.; Liu, Y.-C. Shaking rate during production affects the activity of Escherichia coli surface-displayed Candida antarctica lipase A. Catalysts 2020, 10, 382. [CrossRef]

401. Xu, L.; Xiao, X.; Wang, F.; He, Y.; Yang, X.; Hu, J.; Feng, Z.; Yan, Y. Surface-displayed thermostable Candida rugosa lipase 1 for docosahexaenoic acid enrichment. Appl. Biochem. Biotechnol. 2020,190, 218-231. [CrossRef]

402. Han, Z.; Han, S.; Zheng, S.; Lin, Y. Enhancing thermostability of a Rhizomucor miehei lipase by engineering a disulfide bond and displaying on the yeast cell surface. Appl. Microbiol. Biotechnol. 2009, 85, 117-126. [CrossRef]

403. Matsumoto, T.; Fukuda, H.; Ueda, M.; Tanaka, A.; Kondo, A. Construction of yeast strains with high cell surface lipase activity by using novel display systems based on the Flo1p flocculation functional domain. Appl. Environ. Microbiol. 2002, 68, 4517-4522. [CrossRef]

404. Jin, Z.; Han, S.-Y.; Zhang, L.; Zheng, S.-P.; Wang, Y.; Lin, Y. Combined utilization of lipase-displaying Pichia pastoris whole-cell biocatalysts to improve biodiesel production in co-solvent media. Bioresour. Technol. 2013, 130, 102-109. [CrossRef]

405. Su, F.; Li, G.L.; Fan, Y.L.; Yan, Y.J. Enhancing biodiesel production via a synergic effect between immobilized Rhizopus oryzae lipase and Novozym 435. Fuel Process. Technol. 2015, 137, 298-304. [CrossRef]

406. Jafarian Asl, P.; Niazmand, R.; Jahani, M. Theoretical and experimental assessment of supercritical $\mathrm{CO}_{2}$ in the extraction of phytosterols from rapeseed oil deodorizer distillates. J. Food Eng. 2020, 269, 109748. [CrossRef]

407. Shao, P.; Jiang, S.T.; Ying, Y.J. Optimization of molecular distillation for recovery of tocopherol from rapeseed oil deodorizer distillate using response surface and artificial neural network models. Food Bioprod. Process. 2007, 85, 85-92. [CrossRef]

408. Zhu, Z.N.; Xu, L.; Zhang, H.J.; Yan, Y.J. Efficient production of biodiesel from rapeseed oil deodorizer distillate: One-pot esterification and transesterfication with compound lipases. Appl. Mech. Mater. 2013, 291-294, 267-275. [CrossRef]

409. Pedro, K.; Parreira, J.; Correia, I.; Henriques, C.; Langone, M. Enzymatic biodiesel synthesis from acid oil using a lipase mixture. Quim. Nova 2017, 41, 284-291. [CrossRef]

410. Ibrahim, N.A.; Guo, Z.; Xu, X. Enzymatic interesterification of palm stearin and coconut oil by a dual lipase system. J. Am. Oil Chem. Soc. 2008, 85, 37-45. [CrossRef]

411. Pande, G.; Sabir, J.S.M.; Baeshen, N.A.; Akoh, C.C. Enzymatic synthesis of extra virgin olive oil based infant formula fat analogues containing ARA and DHA: One-stage and two-stage syntheses. J. Agric. Food Chem. 2013, 61, 10590-10598. [CrossRef]

412. Mat Radzi, S.; Abd Rahman, N.J.; Mohd Noor, H.; Basri, M. High yield synthesis of kojic ester using dual enzymes system and their antibacterial activity. Key Eng. Mater. 2013, 594-595, 362-369. [CrossRef]

413. Mat Radzi, S.; Mohd Zulhilmi, M.N.; Mohd Noor, H.; Mohd Rehan, M. Preliminary study on the synthesis of kojic acid monooleate using dual enzymes system. AIP Conf. Proc. 2018, 2030, 020232.

414. Cui, C.; Zhang, Z.; Zeng, Q.; Chen, B. Insight into the synthesis of isosorbide diester plasticizer using immobilized lipases. RSC Adv. 2016, 6, 108180-108186. [CrossRef] 
415. van Buijtenen, J.; van As, B.A.C.; Verbruggen, M.; Roumen, L.; Vekemans, J.A.J.M.; Pieterse, K.; Hilbers, P.A.J.; Hulshof, L.A.; Palmans, A.R.A.; Meijer, E.W. Switching from $S$ - to R-selectivity in the Candida antarctica lipase B-catalyzed ring-opening of $\omega$-methylated lactones: Tuning polymerizations by ring size. J. Am. Chem. Soc. 2007, 129, 7393-7398. [CrossRef]

416. Fernandez-Lorente, G.; Palomo, J.M.; Cabrera, Z.; Fernandez-Lafuente, R.; Guisán, J.M. Improved catalytic properties of immobilized lipases by the presence of very low concentrations of detergents in the reaction medium. Biotechnol. Bioeng. 2007, 97, 242-250. [CrossRef] [PubMed]

417. Matsuda, T.; Kanamaru, R.; Watanabe, K.; Kamitanaka, T.; Harada, T.; Nakamura, K. Control of enantioselectivity of lipase-catalyzed esterification in supercritical carbon dioxide by tuning the pressure and temperature. Tetrahedron Asymmetry 2003, 14, 2087-2091. [CrossRef]

418. Quirós, M.; Parker, M.C.; Turner, N.J. Tuning lipase enantioselectivity in organic media using solid-state buffers. J. Org. Chem. 2001, 66, 5074-5079. [CrossRef] [PubMed]

419. Odaneth, A.A.; Vadgama, R.N.; Bhat, A.D.; Lali, A.M. Tuning lipase reaction for production of fatty acids from oil. Appl. Biochem. Biotechnol. 2016, 180, 504-515. [CrossRef]

420. Acevedo-Rocha, C.G.; Reetz, M.T. Tuning lipase activity with perfluoro carboxylic acids as additives. Catal. Sci. Technol. 2012, 2, 1553-1555. [CrossRef]

421. Palomo, J.M.; Fernandez-Lorente, G.; Mateo, C.; Ortiz, C.; Fernandez-Lafuente, R.; Guisan, J.M. Modulation of the enantioselectivity of lipases via controlled immobilization and medium engineering: Hydrolytic resolution of mandelic acid esters. Enzyme Microb. Technol. 2002, 31, 775-783. [CrossRef]

422. Fernández-Lorente, G.; Palomo, J.M.; Cabrera, Z.; Guisán, J.M.; Fernández-Lafuente, R. Specificity enhancement towards hydrophobic substrates by immobilization of lipases by interfacial activation on hydrophobic supports. Enzyme Microb. Technol. 2007, 41, 565-569. [CrossRef]

423. Palomo, J.M.; Muñoz, G.; Fernández-Lorente, G.; Mateo, C.; Fuentes, M.; Guisan, J.M.; Fernández-Lafuente, R. Modulation of Mucor miehei lipase properties via directed immobilization on different hetero-functional epoxy resins: Hydrolytic resolution of (R,S)-2-butyroyl-2-phenylacetic acid. J. Mol. Catal. B Enzym. 2003, 21, 201-210. [CrossRef]

424. Wilson, L.; Palomo, J.M.; Fernández-Lorente, G.; Illanes, A.; Guisán, J.M.; Fernández-Lafuente, R. Improvement of the functional properties of a thermostable lipase from Alcaligenes sp. via strong adsorption on hydrophobic supports. Enzyme Microb. Technol. 2006, 38, 975-980. [CrossRef]

425. Fernandez-Lorente, G.; Cabrera, Z.; Godoy, C.; Fernandez-Lafuente, R.; Palomo, J.M.; Guisan, J.M. Interfacially activated lipases against hydrophobic supports: Effect of the support nature on the biocatalytic properties. Process Biochem. 2008, 43, 1061-1067. [CrossRef]

426. Cabrera, Z.; Fernandez-Lorente, G.; Fernandez-Lafuente, R.; Palomo, J.M.; Guisan, J.M. Novozym 435 displays very different selectivity compared to lipase from Candida antarctica $B$ adsorbed on other hydrophobic supports. J. Mol. Catal. B Enzym. 2009, 57, 171-176. [CrossRef]

427. Hernandez, K.; Garcia-Galan, C.; Fernandez-Lafuente, R. Simple and efficient immobilization of lipase B from Candida antarctica on porous styrene-divinylbenzene beads. Enzyme Microb. Technol. 2011, 49, 72-78. [CrossRef] [PubMed]

428. Abreu Silveira, E.; Moreno-Perez, S.; Basso, A.; Serban, S.; Pestana Mamede, R.; Tardioli, P.W.; Sanchez Farinas, C.; Rocha-Martin, J.; Fernandez-Lorente, G.; Guisan, J.M. Modulation of the regioselectivity of Thermomyces lanuginosus lipase via biocatalyst engineering for the ethanolysis of oil in fully anhydrous medium. BMC Biotechnol. 2017, 17, 1-13. [CrossRef]

429. Abreu Silveira, E.; Moreno-Perez, S.; Basso, A.; Serban, S.; Pestana-Mamede, R.; Tardioli, P.W.; Farinas, C.S.; Castejon, N.; Fernandez-Lorente, G.; Rocha-Martin, J.; et al. Biocatalyst engineering of Thermomyces Lanuginosus lipase adsorbed on hydrophobic supports: Modulation of enzyme properties for ethanolysis of oil in solvent-free systems. J. Biotechnol. 2019, 289, 126-134. [CrossRef] [PubMed]

430. Toro, E.C.; Rodríguez, D.F.; Morales, N.; García, L.M.; Godoy, C.A. Novel combi-lipase systems for fatty acid ethyl esters production. Catalysts 2019, 9, 546. [CrossRef]

431. Tacias-Pascacio, V.G.; Virgen-Ortíz, J.J.; Jiménez-Pérez, M.; Yates, M.; Torrestiana-Sanchez, B.; Rosales-Quintero, A.; Fernandez-Lafuente, R. Evaluation of different lipase biocatalysts in the production of biodiesel from used cooking oil: Critical role of the immobilization support. Fuel 2017, 200, 1-10. [CrossRef] 
432. Tacias-Pascacio, V.G.; Torrestiana-Sánchez, B.; Dal Magro, L.; Virgen-Ortíz, J.J.; Suárez-Ruíz, F.J.; Rodrigues, R.C.; Fernandez-Lafuente, R. Comparison of acid, basic and enzymatic catalysis on the production of biodiesel after RSM optimization. Renew. Energy 2019, 135, 1-9. [CrossRef]

433. Zhang, G.; Quin, M.B.; Schmidt-Dannert, C. Self-assembling protein scaffold system for easy in vitro coimmobilization of biocatalytic cascade enzymes. ACS Catal. 2018, 8, 5611-5620. [CrossRef]

434. Talekar, S.; Pandharbale, A.; Ladole, M.; Nadar, S.; Mulla, M.; Japhalekar, K.; Pattankude, K.; Arage, D. Carrier free co-immobilization of alpha amylase, glucoamylase and pullulanase as combined cross-linked enzyme aggregates (combi-CLEAs): A tri-enzyme biocatalyst with one pot starch hydrolytic activity. Bioresour. Technol. 2013, 147, 269-275. [CrossRef]

435. Li, Y.; Wen, L.; Tan, T.; Lv, Y. Sequential co-immobilization of enzymes in metal-organic frameworks for efficient biocatalytic conversion of adsorbed $\mathrm{CO}_{2}$ to formate. Front. Bioeng. Biotechnol. 2019, 7, 394. [CrossRef]

436. Lopez-Gallego, F.; Schmidt-Dannert, C. Multi-enzymatic synthesis. Curr. Opin. Chem. Biol. 2010, 14, $174-183$. [CrossRef] [PubMed]

437. Velasco-Lozano, S.; Benítez-Mateos, A.I.; López-Gallego, F. Co-immobilized phosphorylated cofactors and enzymes as self-sufficient heterogeneous biocatalysts for chemical processes. Angew. Chemie Int. Ed. 2017, 56, 771-775. [CrossRef] [PubMed]

438. Schmidt-Dannert, C.; Lopez-Gallego, F. A roadmap for biocatalysis - functional and spatial orchestration of enzyme cascades. Microb. Biotechnol. 2016, 9, 601-609. [CrossRef] [PubMed]

439. Schmid-Dannert, C.; López-Gallego, F. Advances and opportunities for the design of self-sufficient and spatially organized cell-free biocatalytic systems. Curr. Opin. Chem. Biol. 2019, 49, 97-104. [CrossRef] [PubMed]

440. López-Gallego, F.; Jackson, E.; Betancor, L. Heterogeneous systems biocatalysis: The path to the fabrication of self-sufficient artificial metabolic cells. Chem. A Eur. J. 2017, 23, 17841-17849. [CrossRef] [PubMed]

441. Velasco-Lozano, S.; López-Gallego, F. Wiring step-wise reactions with immobilized multi-enzyme systems. Biocatal. Biotransform. 2018, 36, 184-194. [CrossRef]

442. Peirce, S.; Virgen-Ortíz, J.J.; Tacias-Pascacio, V.G.; Rueda, N.; Bartolome-Cabrero, R.; Fernandez-Lopez, L.; Russo, M.E.; Marzocchella, A.; Fernandez-Lafuente, R. Development of simple protocols to solve the problems of enzyme coimmobilization. Application to coimmobilize a lipase and a $\beta$-galactosidase. RSC Adv. 2016, 6, 61707-61715. [CrossRef]

443. Lee, J.H.; Kim, S.B.; Yoo, H.Y.; Lee, J.H.; Park, C.; Han, S.O.; Kim, S.W. Kinetic modeling of biodiesel production by mixed immobilized and co-immobilized lipase systems under two pressure conditions. Korean J. Chem. Eng. 2013, 30, 1272-1276. [CrossRef]

444. Lee, J.H.; Kim, S.B.; Yoo, H.Y.; Lee, J.H.; Han, S.O.; Park, C.; Kim, S.W. Co-immobilization of Candida rugosa and Rhyzopus oryzae lipases and biodiesel production. Korean J. Chem. Eng. 2013, 30, 1335-1338. [CrossRef]

445. Lee, J.H.; Lee, J.H.; Kim, D.S.; Yoo, H.Y.; Park, C.; Kim, S.W. Biodiesel production by lipases co-immobilized on the functionalized activated carbon. Bioresour. Technol. Rep. 2019, 7, 100248. [CrossRef]

446. Shahedi, M.; Yousefi, M.; Habibi, Z.; Mohammadi, M.; As'habi, M.A. Co-immobilization of Rhizomucor miehei lipase and Candida antarctica lipase B and optimization of biocatalytic biodiesel production from palm oil using response surface methodology. Renew. Energy 2019, 141, 847-857. [CrossRef]

447. Kreiner, M.; Parker, M.C. High-activity biocatalysts in organic media: Solid-state buffers as the immobilisation matrix for protein-coated microcrystals. Biotechnol. Bioeng. 2004, 87, 24-33. [CrossRef] [PubMed]

448. Shah, S.; Sharma, A.; Gupta, M.N. Cross-linked protein-coated microcrystals as biocatalysts in non-aqueous solvents. Biocatal. Biotransform. 2008, 26, 266-271. [CrossRef]

449. Yildirim, D.; Toprak, A.; Alagöz, D.; Tukel, S.S. Protein-coated microcrystals of Prunus armeniaca hydroxynitrile lyase: An effective and recyclable biocatalyst for synthesis of (R)-mandelonitrile. Chem. Pap. 2019, 73, 185-193. [CrossRef]

450. Yan, Y.; Xu, L.; Dai, M. A synergetic whole-cell biocatalyst for biodiesel production. RSC Adv. 2012, 2, 6170. [CrossRef]

451. Hepziba Suganthi, S.; Swathi, K.V.; Biswas, R.; Basker, S.; Ramani, K. Co-immobilization of multiple enzymes onto surface-functionalized magnetic nanoparticle for the simultaneous hydrolysis of multiple substrates containing industrial wastes. Appl. Nanosci. 2019, 9, 1439-1457. [CrossRef]

452. Dalal, S.; Kapoor, M.; Gupta, M.N. Preparation and characterization of combi-CLEAs catalyzing multiple non-cascade reactions. J. Mol. Catal. B Enzym. 2007, 44, 128-132. [CrossRef] 
453. Zaak, H.; Kornecki, J.F.; Siar, E.-H.; Fernandez-Lopez, L.; Corberán, V.C.; Sassi, M.; Fernandez-Lafuente, R. Coimmobilization of enzymes in bilayers using PEI as a glue to reuse the most stable enzyme: Preventing pei release during inactivated enzyme desorption. Process Biochem. 2017, 61, 95-101. [CrossRef]

454. Arana-Peña, S.; Mendez-Sanchez, C.; Rios, N.S.; Ortiz, C.; Gonçalves, L.R.B.; Fernandez-Lafuente, R. New applications of glyoxyl-octyl agarose in lipases co-immobilization: Strategies to reuse the most stable lipase. Int. J. Biol. Macromol. 2019, 131, 989-997. [CrossRef]

455. Rios, N.S.; Arana-Peña, S.; Mendez-Sanchez, C.; Ortiz, C.; Gonçalves, L.R.B.; Fernandez-Lafuente, R. Reuse of lipase from Pseudomonas fluorescens via its step-by-step coimmobilization on glyoxyl-octyl agarose beads with least stable lipases. Catalysts 2019, 9, 487. [CrossRef]

456. Rios, N.S.; Arana-Peña, S.; Mendez-Sanchez, C.; Lokha, Y.; Cortes-Corberan, V.; Gonçalves, L.R.B.; Fernandez-Lafuente, R. Increasing the enzyme loading capacity of porous supports by a layer-by-layer immobilization strategy using PEI as glue. Catalysts 2019, 9, 576. [CrossRef]

457. Arana-Peña, S.; Rios, N.S.; Mendez-Sanchez, C.; Lokha, Y.; Gonçalves, L.R.B.; Fernández-Lafuente, R. Use of polyethylenimine to produce immobilized lipase multilayers biocatalysts with very high volumetric activity using octyl-agarose beads: Avoiding enzyme release during multilayer production. Enzyme Microb. Technol. 2020, 137, 109535. [CrossRef] [PubMed]

458. Arana-Peña, S.; Rios, N.S.; Mendez-Sanchez, C.; Lokha, Y.; Carballares, D.; Gonçalves, L.R.B.; Fernandez-Lafuente, R. Coimmobilization of different lipases: Simple layer by layer enzyme spatial ordering. Int. J. Biol. Macromol. 2019, 145, 856-864. [CrossRef] [PubMed]

459. Arana-Peña, S.; Carballares, D.; Fernandez-Lafuente, R. Multi-combilipases: Coimmobilizing lipases with very different stabilities combining immobilization via interfacial activation and ion exchange: The reuse of the most stable coimmobilized enzymes after inactivation of the least stable enzymes. Catalysts In preparation.

(C) 2020 by the authors. Licensee MDPI, Basel, Switzerland. This article is an open access article distributed under the terms and conditions of the Creative Commons Attribution (CC BY) license (http://creativecommons.org/licenses/by/4.0/). 